Prepared in cooperation with the Upper Cape Fear River Basin Association

\title{
Suspended Sediment and Nutrients in the Upper Cape Fear River Basin, North Carolina, 2002-04, with an Analysis of Temporal Changes, 1976-2004
}

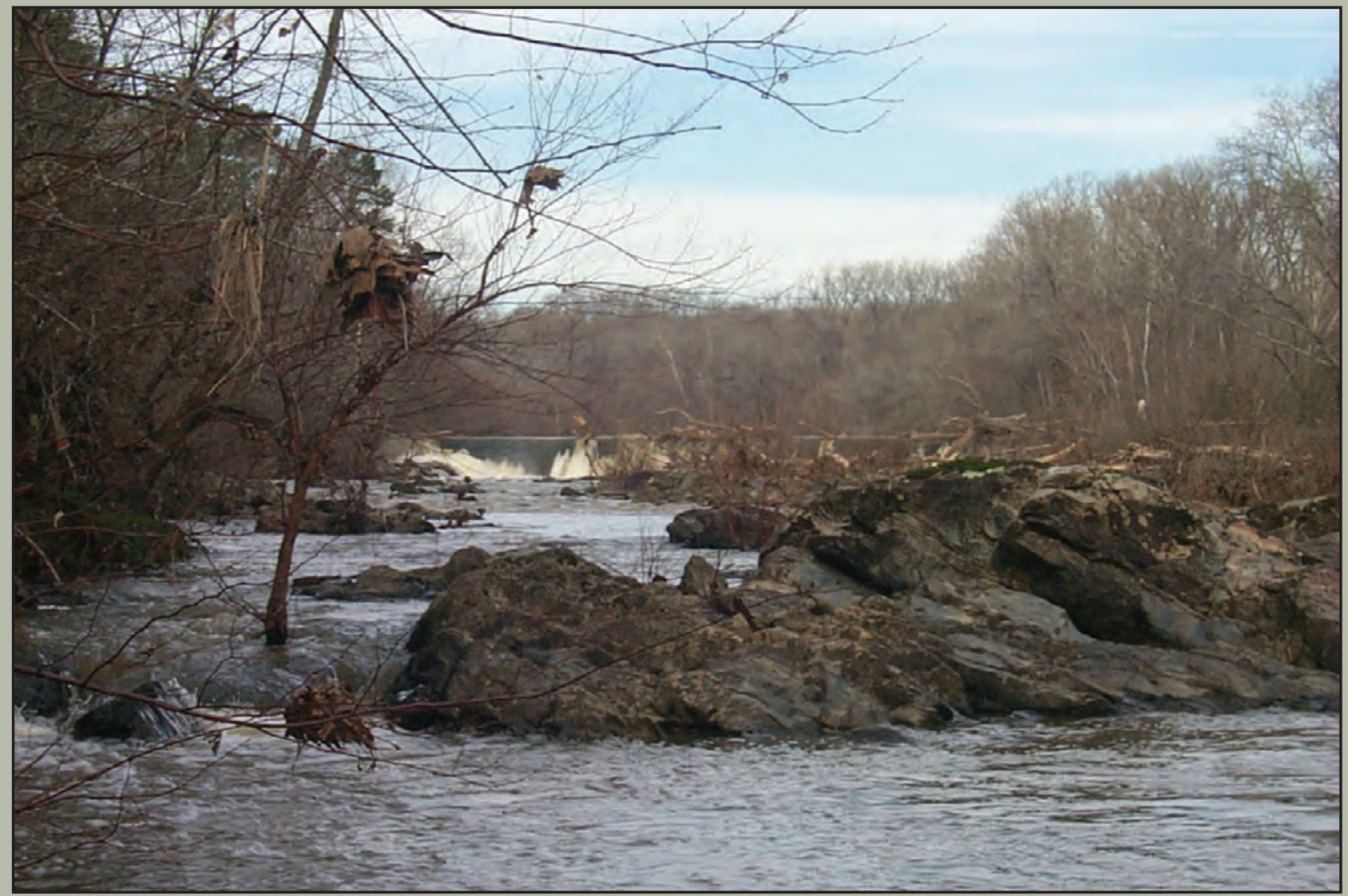

Scientific Investigations Report 2005-5271 
Cover. Deep River spillway upstream from the U.S. highway 1 bridge in Chatham County, North Carolina (photograph by Ryan B. Rasmussen, U.S. Geological Survey). 


\section{Suspended Sediment and Nutrients in the Upper Cape Fear River Basin, North Carolina, 2002-04, with an Analysis of Temporal Changes, 1976-2004}

By Timothy B. Spruill, Phillip S. Jen, and Ryan B. Rasmussen

Prepared in cooperation with the Upper Cape Fear River Basin Association

Scientific Investigations Report 2005-5271 


\section{U.S. Department of the Interior \\ Gale A. Norton, Secretary \\ U.S. Geological Survey \\ P. Patrick Leahy, Acting Director}

\section{U.S. Geological Survey, Reston, Virginia: 2006}

For product and ordering information:

World Wide Web: http://www.usgs.gov/pubprod

Telephone: 1-888-ASK-USGS

For more information on the USGS--the Federal source for science about the Earth, its natural and living resources, natural hazards, and the environment:

World Wide Web: http://www.usgs.gov

Telephone: 1-888-ASK-USGS

Any use of trade, product, or firm names is for descriptive purposes only and does not imply endorsement by the U.S. Government.

Although this report is in the public domain, permission must be secured from the individual copyright owners to reproduce any copyrighted materials contained within this report.

Suggested citation:

Spruill, T.B., Jen, P.S., and Rasmussen, R.B., 2006, Suspended sediment and nutrients in the upper Cape Fear River basin, North Carolina, 2002-04, with an analysis of temporal changes, 1976-2004: U.S. Geological Survey Scientific Investigations Report 2005-5271, 40 p. 


\section{Contents}

Abstract

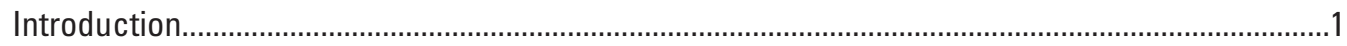

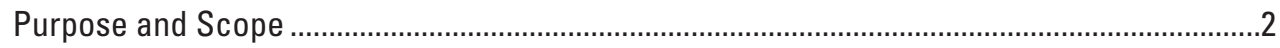

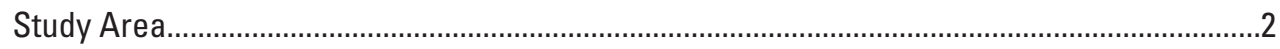

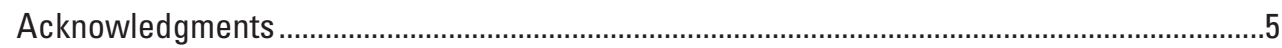

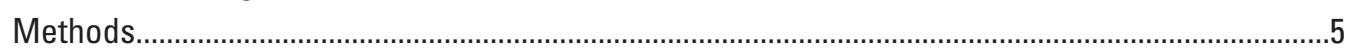

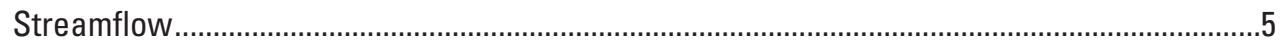

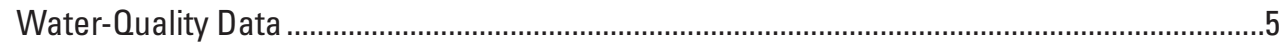

Load-Estimation Techniques for Data Collected during 2002-04...........................................

Load-Estimation Techniques for Historical Data ……...........................................................

Analysis of Temporal Changes ........................................................................................

Streamflow, Suspended Sediment, and Nutrient Concentrations and Loads in the Upper Cape Fear River Basin, 2002-04 .....................................................................................

Nutrient and Suspended-Sediment Concentrations..................................................................

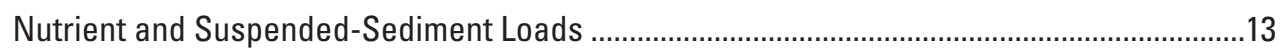

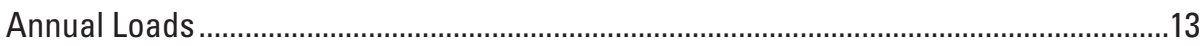

Seasonal Loads ........................................................................................................14

Historical Changes in Streamflow, Suspended-Sediment, and Nutrient Concentrations

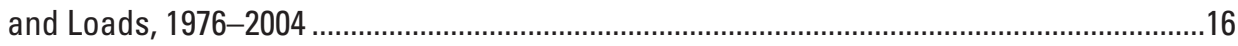

Streamflow in the Haw River near Bynum .......................................................................17

Suspended Sediment in the Haw River near Bynum ...........................................................17

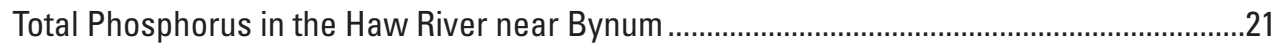

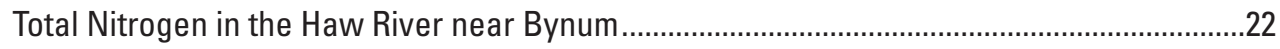

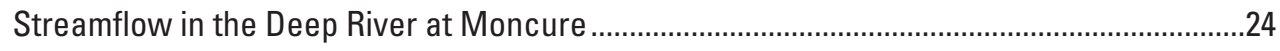

Suspended Sediment in the Deep River at Moncure ..........................................................2

Total Phosphorus in the Deep River at Moncure...................................................................26

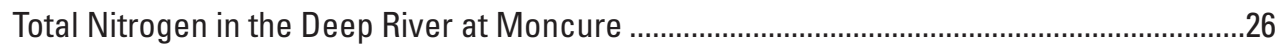

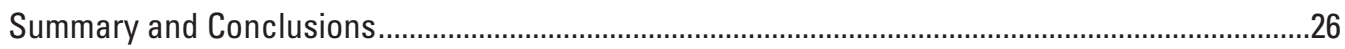

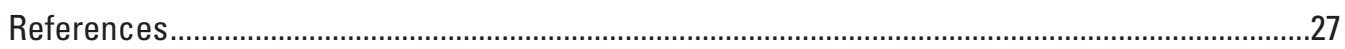

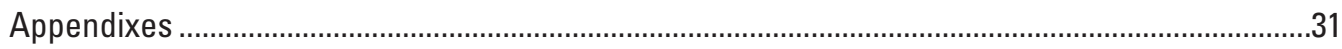

\section{Figures}

1. Locations of sampling sites in the Haw River and Deep River subbasins of the upper Cape Fear River basin, North Carolina, 2002-04 .....................................................

2. Box plots of streamflow in the (A) Haw River near Bynum and (B) Deep River at Moncure, North Carolina, for water years 2002-04 ......................................................

3. Water types for the (A) Haw River near Bynum and (B) Deep River at Moncure, North Carolina, 2002-04.

4. Box plots of $(A)$ total phosphorus, (B) total nitrogen, and (C) suspended-sediment concentrations in the Haw River near Bynum and the Deep River at Moncure, North Carolina, 2002-04. 
5. Seasonal concentrations of (A) suspended sediment, (B) orthophosphate, and (C) total nitrogen in the Haw River near Bynum and the Deep River at Moncure, North Carolina, 2002-04

6. Seasonal loads of suspended sediment, total phosphorus, and total nitrogen in the Haw River near Bynum and the Deep River at Moncure, North Carolina, for water years 2003 and 2004

7. Box plots of annual streamflow in the Haw River near Bynum, North Carolina, 1976-2004

8. Relation of (A) suspended-sediment data collected by the U.S. Geological Survey and (B) total suspended-solids data collected by the North Carolina Division of Water Quality to streamflow at the Haw River near Bynum, North Carolina, 1981-2004.

9. Box plots of (A) suspended-sediment concentrations for 1976-85 and 2002-04 from the U.S. Geological Survey, and (B) total suspended-solids concentrations for 1981-91 and 1992-2004 from the North Carolina Division of Water Quality at the Haw River near Bynum, North Carolina.

10. Box plots of suspended-sediment concentrations at four different streamflow ranges for (A) 1976-85 and (B) 2002-04 in the Haw River near Bynum,

North Carolina

11. Total phosphorus data from (A) the North Carolina Division of Water Quality and (B) the U.S. Geological Survey for the Haw River near Bynum, North Carolina, 1980-2004, and trends indicated by LOWESS smooth lines

12. Box plots of instantaneous phosphorus loads for 1981-85 and 2002-04 at the Haw River near Bynum, North Carolina.

13. Total nitrogen concentrations from U.S. Geological Survey and North Carolina Division of Water Quality databases for the Haw River near Bynum, North Carolina, 1981-2003.

14. Box plots of annual streamflow in the Deep River at Moncure, North Carolina, 1976-2004

\section{Tables}

1. Characteristics of (A) land use and (B) population and wastewater discharges in the Haw River and Deep River subbasins of North Carolina

2. Analytical methods and reporting levels for nutrients and suspended sediment.............5

3. Analytical methods and reporting levels for dissolved major ions and selected trace elements

4. List of regression models included in LOADEST computations

5. Selected streamflow statistics from the Haw River near Bynum and the Deep River at Moncure, North Carolina

6. Statistical summary of nutrient and suspended-sediment concentrations in the Haw and Deep Rivers, North Carolina, 2002-04.

7. Nutrient and sediment loads and yields in the Haw and Deep Rivers, North Carolina, for calendar years 2002 and 2003

8. Seasonal loads of nutrients and suspended sediment in the Haw River near Bynum and the Deep River at Moncure, North Carolina, during September 2002-August 2004 
9. Annual suspended-sediment loads for calendar year 1976-2003 streamflows in the Haw River near Bynum, North Carolina, for two calibration periods, 1976-89 and 2002-04

10. Annual phosphorus loads for calendar year 1976-2003 streamflows in the Haw River near Bynum, North Carolina, for two calibration periods, 1976-89 and 2002-04

11. Annual total nitrogen loads for calendar year 1976-2003 streamflows in the Haw River near Bynum, North Carolina, for two calibration periods, 1981-85 and 2002-04

12. Annual suspended-sediment loads for calendar year 1976-2003 streamflows in the Deep River at Moncure, North Carolina, for two calibration periods, 1976-83 and 2002-04

\section{Appendixes}

Appendix 1. Nutrient and suspended-sediment concentrations in water samples from the Haw River near Bynum, North Carolina..

Appendix 2. Nutrient and suspended-sediment concentrations in water samples from the Deep River at Moncure, North Carolina .

Appendix 3. Selected major ions and trace element concentrations in water samples from (A) the Haw River near Bynum and (B) the Deep River at Moncure, North Carolina

Appendix 4. Equations used in load calculations for suspended sediment, total nitrogen, and phosphorus in (A) the Haw River near Bynum and (B) the Deep River at Moncure, North Carolina...

Appendix 5. Planted crop acreage in counties in the upper Cape Fear River basin, 1980-2004 


\section{Conversion Factors, Datum, and Acronyms}

\begin{tabular}{|c|c|c|}
\hline Multiply & By & To obtain \\
\hline \multicolumn{3}{|c|}{ Length } \\
\hline mile (mi) & 1.609 & kilometer $(\mathrm{km})$ \\
\hline \multicolumn{3}{|c|}{ Area } \\
\hline square mile $\left(\mathrm{mi}^{2}\right)$ & 2.590 & square kilometer $\left(\mathrm{km}^{2}\right)$ \\
\hline \multicolumn{3}{|c|}{ Flow rate } \\
\hline cubic foot per second $\left(\mathrm{ft}^{3} / \mathrm{s}\right)$ & 0.02832 & cubic meter per second $\left(\mathrm{m}^{3} / \mathrm{s}\right)$ \\
\hline million gallons per day (Mgal/d) & 0.04381 & cubic meter per second $\left(\mathrm{m}^{3} / \mathrm{s}\right)$ \\
\hline ton per day (ton/d) & 0.9072 & megagram per day $(\mathrm{Mg} / \mathrm{d})$ \\
\hline $\begin{array}{l}\text { ton per year per square mile } \\
{\left[(\text { ton } / \mathrm{yr}) / \mathrm{mi}^{2}\right]}\end{array}$ & 0.3503 & $\begin{array}{l}\text { megagram per year per square } \\
\text { kilometer }\left[(\mathrm{Mg} / \mathrm{yr}) / \mathrm{km}^{2}\right]\end{array}$ \\
\hline
\end{tabular}

Water temperature was recorded in degrees Celsius $\left({ }^{\circ} \mathrm{C}\right)$, which may be converted to degrees Fahrenheit $\left({ }^{\circ} \mathrm{F}\right)$ as follows:

$$
{ }^{\circ} \mathrm{F}=\left(1.8 \times{ }^{\circ} \mathrm{C}\right)+32
$$

Specific conductance was measured in microsiemens per centimeter at 25 degrees Celsius $\left(\mu \mathrm{S} / \mathrm{cm}\right.$ at $\left.25^{\circ} \mathrm{C}\right)$.

Concentrations of chemical constituents in water are given either in milligrams per liter (mg/L) or micrograms per liter ( $\mu \mathrm{g} / \mathrm{L})$.

Horizontal coordinate information (latitude and longitude) is referenced to the North American Datum of 1983 (NAD 83).

\section{Acronyms}

$\begin{array}{ll}\text { AIC } & \text { Akaike information criterion } \\ \text { AMLE } & \text { adjusted maximum likelihood estimator } \\ \text { ASF } & \text { automated segmented-flow spectrophotometry } \\ \text { DCP } & \text { data-collection platform } \\ \text { EROS } & \text { Earth Resources Observation and Science } \\ \text { EWI } & \text { equal-width increment } \\ \text { LAD } & \text { least absolute deviation } \\ \text { LT } & \text { Landsat thematic (map data) } \\ \text { MLE } & \text { maximum likelihood estimator } \\ \text { MRLC } & \text { Multi-Resolution Land Characteristics } \\ \text { N } & \text { nitrogen } \\ \text { NC } & \text { North Carolina } \\ \text { NCDWQ } & \text { North Carolina Division of Water Quality } \\ \text { NO }+ \text { NO } & \text { nitrite plus nitrate } \\ \text { NPDES } & \text { National Pollutant Discharge Elimination System } \\ \text { NRI } & \text { National Resource Inventory } \\ \text { NWIS } & \text { National Water Information System } \\ \text { NWQL } & \text { National Water Quality Laboratory } \\ \text { P } & \text { phosphorus } \\ \text { UCFRBA } & \text { Upper Cape Fear River Basin Association } \\ \text { USDA } & \text { U.S. Department of Agriculture } \\ \text { USEPA } & \text { U.S. Environmental Protection Agency } \\ \text { USGS } & \text { U.S. Geological Survey }\end{array}$




\title{
Suspended Sediment and Nutrients in the Upper Cape Fear River Basin, North Carolina, 2002-04, with an Analysis of Temporal Changes, 1976-2004
}

\author{
By Timothy B. Spruill, Phillip S. Jen, and Ryan B. Rasmussen
}

\section{Abstract}

An investigation of suspended sediment and nutrients was conducted in the Haw River near Bynum and in the Deep River at Moncure, North Carolina, to characterize water quality based on data collected weekly or biweekly between August 2002 and August 2004. Samples were collected five times per year for selected major ions and trace elements to help in characterizing the water quality at these sampling sites. Sediment and nutrient data collected from 1976 to 2004 also were analyzed to evaluate whether loads and concentrations changed significantly over this period.

The water chemistry in the Haw and Deep Rivers is of mixed ionic composition, although the water chemistry in the Haw River is more variable. Water types in both rivers generally shifted from calcium and bicarbonate in the winter and spring months and during high flows to sodium and chloride during low flows in the summer. Sediment and nutrient loads were estimated for calendar years 2002 and 2003 using the nutrient and suspended-sediment concentration data collected between 2002 and 2004 for calibration of regression load models. Sediment and nutrient loads generally were greater in 2003, an unusually wet year, than in 2002. Annual constituent yields generally were higher in the Deep River with the exception of dissolved nitrate and nitrite. Phosphorus loads and concentrations were significantly higher in the Deep River as a result of substantial continuous-discharge sources of phosphorus, particularly near High Point, North Carolina. More stringent wastewater-treatment requirements in the Haw River primarily are responsible for much lower phosphorus concentrations and loads compared with those in the Deep River. Seasonal loads were evaluated at both sites for the period September 2002 through August 2004. Primary transport of nutrients and sediment occurred during spring 2003 and winter 2004.

Historical flow and water-quality data previously collected at both sites by the U.S. Geological Survey and the North Carolina Division of Water Quality were used to evaluate historical changes through time and to compare information from the two datasets. Historical water-quality changes between 1976 and 2004 were greatest in the Haw River near Bynum, which had a statistically significant ( $\mathrm{p}$ is less than 0.05) decrease in sediment, total nitrogen, and total phosphorus concentrations and loads. Decreases in cultivated land, improved land-management practices, and improved wastewater-treatment processes since the 1980s are primary reasons for the observed improvement in water quality in the Haw River.

Because sampling was limited for nutrients (16 samples) and sediment (25 samples) in the Deep River, changes in concentrations between the early 1980s and 2002-04 were not statistically detectable ( $p$ is greater than 0.05 ) for suspended sediment, total nitrogen, or total phosphorus. Data from the North Carolina Division of Water Quality also indicated no change between 1992 and 2004. Calculated sediment loads, however, using the load-streamflow regression models calibrated for two separate periods, 1976-83 and 2002-04, indicate that sediment loads may be lower for 2002-04 compared with those in the early 1980s. Nutrient concentrations have remained relatively unchanged since the 1980s.

\section{Introduction}

The Upper Cape Fear River Basin Association (UCFRBA) in North Carolina established a 44-station waterquality sampling network in 2000 to support analyses of water quality in the Haw and Deep River basins and to serve as a basis for providing recommendations to local, State, and Federal authorities regarding maintenance and improvement of water quality and water resources in the upper Cape Fear River basin. The monitoring network was established under an agreement with the North Carolina Division of Water Quality (NCDWQ) and supersedes the NCDWQ in-stream monitoring requirements for point-source discharge facilities that participate in the UCFRBA monitoring program. 
To supplement these data, current information was needed on stream discharge and water quality at selected sites in the basin that are not directly influenced by point sources. Of particular importance were water-quality data for the Haw River above Jordan Lake and the Deep River before its confluence with the Haw River to form the Cape Fear River to document water-quality conditions in the upper part of the basin with respect to nutrients and sediment and excluding the effects of Jordan Lake. Such data, combined with data collected by the Lower Cape Fear River Program and Middle Cape Fear River Basin Association, will provide waterresource managers with a regional perspective on water quality in the Cape Fear River basin. In addition, data collected during the past 30 years from the upper Cape Fear River basin by the U.S. Geological Survey (USGS) and the NCDWQ are valuable in assessing changes in water quality in response to land use and other environmental and climatic factors.

The USGS, in cooperation with the UCFRBA, began a study in 2002 to collect and evaluate current water-quality data over a range of flows in the Deep and Haw Rivers in order to quantitatively assess loads of nutrients and sediment transported from these two major tributaries of the upper Cape Fear River basin. In addition, historical data collected by the USGS and NCDWQ were compiled and analyzed to evaluate whether loads and concentrations of nutrients and sediment have changed over the past approximately 30 years.

\section{Purpose and Scope}

This report presents (1) water-quality and streamflow data collected from August 2002 through August 2004 from the Haw River near Bynum and the Deep River at Moncure in North Carolina (fig. 1), and (2) an evaluation of historical data defining general water quality and suspended sediment, total suspended solids, and nutrient loads transported at these two sites between 1976 and 2004 to determine if loads and concentrations have changed. Because the two sampling sites are located at the most downstream part of each river subbasin (fig. 1), the data can be used to evaluate current (2004) water-quality characteristics in both rivers resulting from land use in the upstream areas. In addition, evaluation of historical data enables the UCFRBA to determine whether water-quality changes have occurred in the basins.

\section{Study Area}

The upper Cape Fear River basin is located in the Piedmont Physiographic Province of North Carolina (fig. 1). The entire 3,100-square-mile $\left(\mathrm{mi}^{2}\right)$ upper Cape Fear River basin (Upper Cape Fear River Basin Association, 2005) consists of the drainage area above the confluence of the Haw and Deep Rivers where they form the Cape Fear River (fig. 1). The headwaters of the Haw River originate near Greensboro,
North Carolina (NC). From there, the river flows eastward through northern Guilford County and then southeast though Burlington in Alamance County and empties into Jordan Lake near Pittsboro in Chatham County (fig. 1). The headwaters of the Deep River also begin in Guilford County but near High Point, and the river flows southeast through Randolph County into Moore County where it turns and flows northeast along the border of Chatham and Lee Counties before joining the Haw River southeast of Moncure to form the Cape Fear River (fig. 1).

The study area includes the entire Deep River subbasin and only part of the Haw River subbasin-Jordan Lake and the creeks that drain into it are excluded (fig. 1). The approximately 2,700- $\mathrm{mi}^{2}$ area (table 1A) of these two subbasins in $2001^{\mathrm{a}}$ consisted primarily of forested areas (49.5 percent of the land use). Developed land and urban areas composed 14.2 percent of the land use in the basin, and cultivated and planted lands composed 25.1 percent. The remaining area was composed of 1.9 percent water and wetlands and 0.3 percent barren land. Although these data are not directly comparable with 1992 data $^{\mathrm{a}}$, forested areas generally decreased, developed (or urban) areas increased, and cultivated and planted lands remained about the same (table 1A). Human population in the more urban Haw River subbasin is almost twice the population of the Deep River subbasin and increased approximately 30 percent and 18 percent in the Haw and Deep River subbasins, respectively, between 1990 and 2000 (table 1B). With respect to animal populations, the Deep River subbasin had about 7 times as many swine, 5 times as many poultry, and slightly fewer dairy cattle compared with the Haw River subbasin (table 1B). About 50 National Pollutant Discharge Elimination System (NPDES) wastewater dischargers are in each subbasin in the study area (fig. 1), and almost twice as much waste discharge is permitted in the Haw River subbasin compared with the Deep River subbasin (97 and 53 million gallons per day (Mgal/d), respectively; table 1B).

Two stations were selected for streamflow measurement and water-quality sampling near the confluence of the two rivers-USGS streamgaging station 02096960 on the Haw

\footnotetext{
${ }^{\mathrm{a}}$ At least three sources of land-use data were available for the study area-(1) National Multi-Resolution Land Characteristics (MRLC; Bara, 1994) based on Landsat Thematic Mapper (LT) data from 1992 using nationally consistent land-use classes; (2) North Carolina 1996 land-use/land-cover data based on 1993-95 LT land-cover classifications in Earth Satellite Corporation (1997) and used by the North Carolina Division of Water Quality (2005a); and (3) MRLC data based on 2001 Landsat 7 LT data using nationally consistent land-use classes. None of these datasets are directly comparable between years because land-use classifications may differ even though the category names may be identical. The 1992 and 2001 MRLC data were used to characterize general land-use characteristics in the Haw and Deep River subbasins for this report because they are based on consistently pre-processed Landsat 7 LT data that are nationally comparable and readily available, and consistently segregate unmanaged and managed land uses.
} 


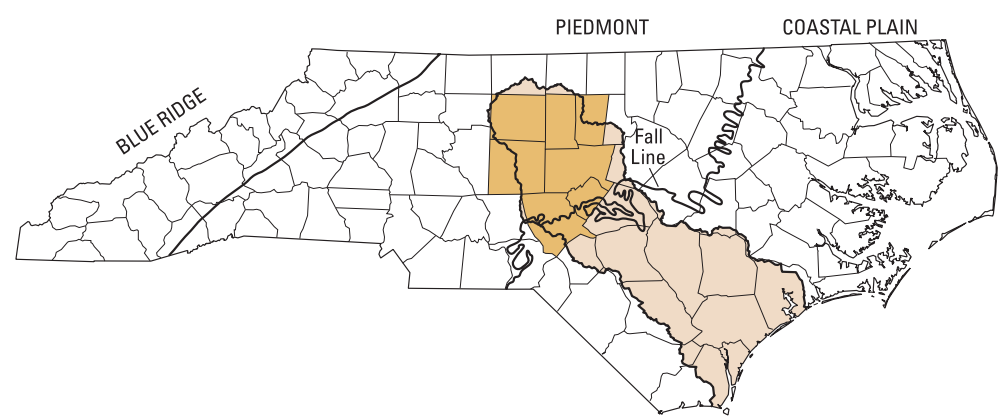

MAP SHOWING COUNTIES IN THE STUDY AREA, CAPE FEAR RIVER BASIN, AND PHYSIOGRAPHIC PROVINCES IN NORTH CAROLINA

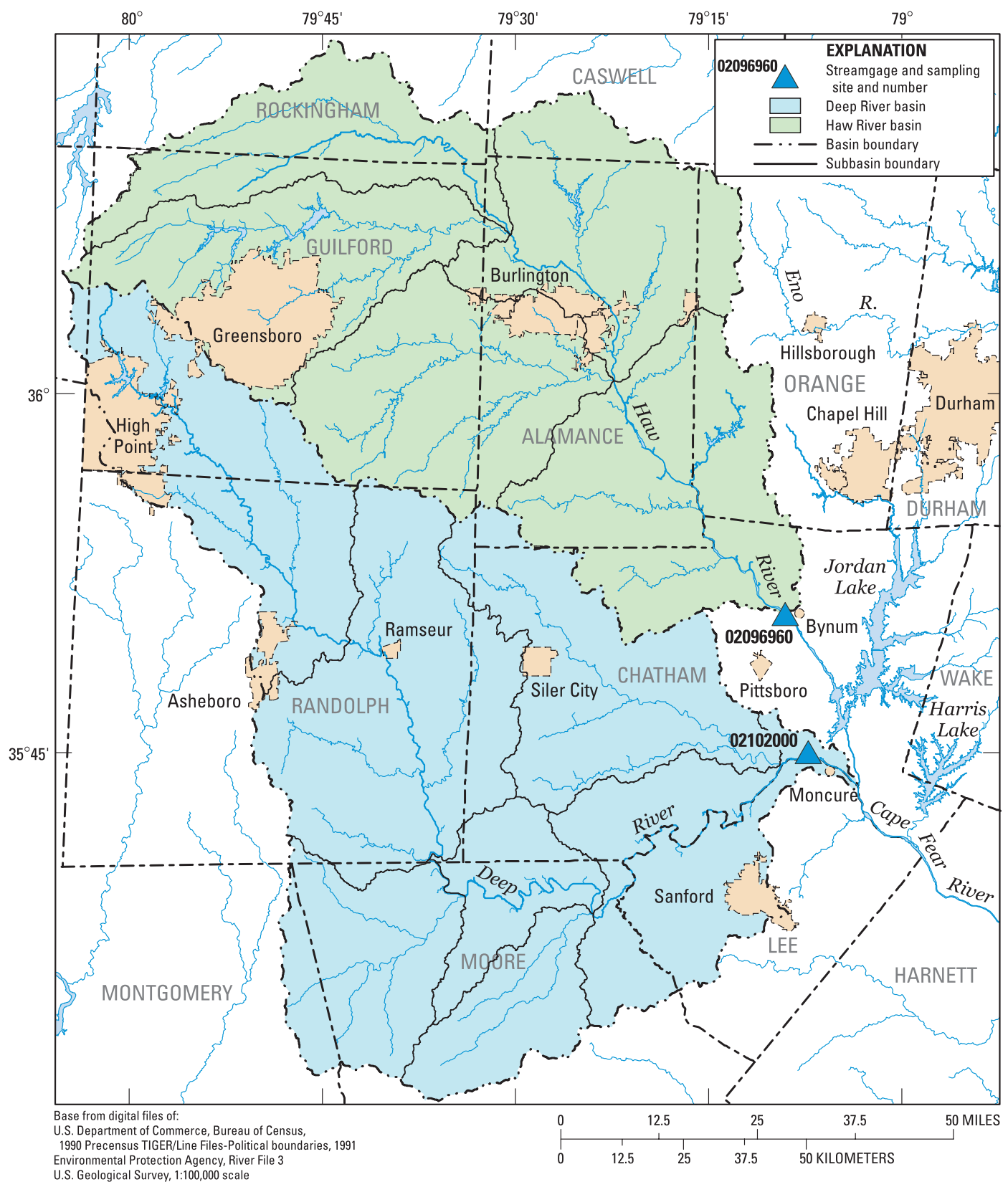

Figure 1. Locations of sampling sites in the Haw River and Deep River subbasins of the upper Cape Fear River basin, North Carolina, 2002-04. 
Table 1. Characteristics of (A) land use and (B) population and wastewater discharges in the Haw River and Deep River subbasins of North Carolina.

[—, no category; land-use data are from 1992 and 2001 Multi-Resolution Land Characteristics (MRLC) land use/land cover coverages available from the U.S. Geological Survey's Earth Resources Observation and Science (EROS) Data Center in Sioux Falls, South Dakota, and accessed in 2005 at $h t t p: / / e d c . u s g s$. gov/products/landcover.html]

A. Land use

\begin{tabular}{|c|c|c|c|c|c|c|c|c|c|c|}
\hline \multirow{3}{*}{ Land-use class } & \multicolumn{4}{|c|}{ Haw River subbasin } & \multicolumn{4}{|c|}{ Deep River subbasin } & \multirow{2}{*}{\multicolumn{2}{|c|}{$\begin{array}{c}\text { Total } \\
\text { percentages }\end{array}$}} \\
\hline & \multicolumn{2}{|c|}{ Square miles } & \multicolumn{2}{|c|}{ Percentage } & \multicolumn{2}{|c|}{ Square miles } & \multicolumn{2}{|c|}{ Percentage } & & \\
\hline & 1992 & 2001 & 1992 & 2001 & 1992 & 2001 & 1992 & 2001 & 1992 & 2001 \\
\hline Water & 17 & 19.1 & 1.2 & 1.5 & 8.4 & 9.2 & 0.6 & 0.6 & 0.9 & 1 \\
\hline Developed & 127.8 & 222.3 & 10.1 & 17.5 & 73.4 & 163.2 & 5.1 & 11.3 & 7.4 & 14.2 \\
\hline Barren & 5.9 & 2 & 0.5 & 0.2 & 19.4 & 4.8 & 1.3 & 0.3 & 0.9 & 0.3 \\
\hline Forested & 747.6 & 556.6 & 58.8 & 43.8 & $1,052.4$ & 786.2 & 73 & 54.5 & 66.3 & 49.5 \\
\hline Planted/cultivated & 358.4 & 358.9 & 28.2 & 28.2 & 272.1 & 321.6 & 18.9 & 22.4 & 23.3 & 25.1 \\
\hline Shrub/scrub & 一 & 47 & 一 & 3.7 & 一 & 78.1 & 一 & 5.4 & 一 & 4.6 \\
\hline Grassland/herbaceous & 一 & 53.1 & 一 & 4.2 & 一 & 66.2 & 一 & 4.6 & 一 & 4.4 \\
\hline Wetlands & 15 & 13.2 & 1.2 & 1 & 16.6 & 13.1 & 1.1 & 0.9 & 1.2 & 0.9 \\
\hline Total & 1,272 & 1,272 & 100 & 100 & 1,442 & 1,442 & 100 & 100 & 100 & 100 \\
\hline
\end{tabular}

B. Population data and wastewater discharges permitted by the National Pollutant Discharge Elimination System (NPDES) [Data from North Carolina Division of Water Quality (2000, 2005a)]

Population for year(s) shown

\begin{tabular}{|c|c|c|c|c|c|c|c|}
\hline \multirow{2}{*}{$\begin{array}{l}\text { Humans } \\
1990 / 2000\end{array}$} & \multicolumn{3}{|c|}{ Haw River subbasin } & \multicolumn{4}{|c|}{ Deep River subbasin } \\
\hline & $\begin{array}{c}\text { Swine } \\
1998\end{array}$ & $\begin{array}{c}\text { Dairy cattle } \\
1998\end{array}$ & $\begin{array}{c}\text { Poultry } \\
1998\end{array}$ & $\begin{array}{l}\text { Humans } \\
1990 / 2000\end{array}$ & $\begin{array}{c}\text { Swine } \\
1998\end{array}$ & $\begin{array}{c}\text { Dairy cattle } \\
1998\end{array}$ & $\begin{array}{c}\text { Poultry } \\
1998\end{array}$ \\
\hline \multicolumn{8}{|c|}{ NPDES-permitted wastewater discharges } \\
\hline & \multicolumn{3}{|c|}{ Haw River subbasin } & \multicolumn{2}{|c|}{ Deep River subbasin } & & \\
\hline Amount, in million & is per day & \multicolumn{2}{|c|}{97.3} & \multicolumn{2}{|c|}{52.9} & & \\
\hline
\end{tabular}

River near Bynum, which has a drainage area ${ }^{\mathrm{b}}$ of $1,275 \mathrm{mi}^{2}$, and USGS streamgaging station 02102000 on the Deep River at Moncure, which has a drainage area ${ }^{\mathrm{b}}$ of 1,434 $\mathrm{mi}^{2}$ (fig. 1). These two stations drain about $2,700 \mathrm{mi}^{2}$, or about 90 percent of the upper Cape Fear drainage basin. Because the Haw River above Jordan Lake (fig. 1) is the primary focus of this study, the 10 percent of the Haw River subbasin that includes Jordan Lake and streams draining Chapel Hill and Durham was excluded.

The sampling site and streamgage on the Haw River near Bynum are located about 10 miles (mi) upstream from Jordan Lake (fig. 1). Streamflow data have been collected continuously at this site since October 1973 (Ragland and others,

\footnotetext{
${ }^{\mathrm{b}}$ Drainage areas stored in the U.S. Geological Survey's National Water Information System (NWIS) generally are determined from 1:24,000 topographic maps published by the U.S. Geological Survey. These drainage areas may vary from areas determined from other sources. Detailed site information for these stations are presented in Ragland and others (2004).
}

2004). Water-quality samples have been collected periodically at this site by the USGS since September 1976. The NCDWQ has collected quarterly to monthly samples for selected chemical constituents, including total suspended solids and nutrients, since July 1968 (North Carolina Division of Water Quality, 2005b).

The sampling site and streamgage on the Deep River at Moncure are located about 4.5 mi upstream from the confluence of the Haw and Deep Rivers (fig. 1). This site was established in July 1930, and streamflow data are still (2004) being collected at this site. Water-quality samples have been collected at this site by the USGS since June 1955; however, like the Haw River, samples were not collected with sufficient frequency for reliable load analysis until 1976 for sediment and 1981 for nutrients. Samples for total suspended solids and nutrients have been collected at this site by the NCDWQ since April 1992 (Andrea Thomas, North Carolina Division of Water Quality, written commun., July 2005). 


\section{Acknowledgments}

This study was conducted by the USGS in cooperation with the UCFRBA. The authors thank Carol Patrick, Mike Hite, and Sydney Miller of the UCFRBA for their cooperation in this study; Susan Gale and Andrea Thomas of the Environmental Sciences Section of the NCDWQ; and Tami Idol of the North Carolina Division of Land Resources. Further thanks go to the USGS field office staff in Raleigh, NC; to Mary Giorgino and Carolyn Oblinger of the USGS North Carolina Water Science Center for their support and guidance throughout this project; and to the reviewers of this report.

\section{Methods}

Methods that were used in the collection and interpretation of water-quality data are described here. Methods used for surface-water data collection and analysis and the statistical procedures to analyze the data also are included.

\section{Streamflow}

Streamflow, also referred to as stream discharge, was measured and recorded during this investigation according to standard USGS methods (Rantz and others, 1982). Both sites were equipped with data-collection platforms (DCPs) that record river stage at 15-minute intervals. Instantaneous streamflow was calculated at the time that stream-stage records were transmitted to the USGS National Water Information System (NWIS). Streamflow data have been collected at the Haw River near Bynum since 1973 and at the Deep River at Moncure since 1930 (Ragland and others, 2004).

\section{Water-Quality Data}

All water-quality data collected by the USGS in the study area during 2002-04 were collected in accordance with
USGS protocols (U.S. Geological Survey, variously dated). Alkalinity, $\mathrm{pH}$, specific conductance, dissolved oxygen, and temperature were measured in the field. Field properties and nutrient and suspended-sediment samples were collected approximately weekly from August 2002 to January 2004 and biweekly from January 2004 to August 2004. At each site, 10 samples were collected for major ions and trace elements, 7 of which were collected during periods of runoff.

The equal-width-increment (EWI) method of sampling was used, because it ensures a depth- and width-integrated sample representative of the entire stream cross section. Isokinetic samplers were used to collect multiple vertical subsamples while wading the cross section or by deploying a sampler from the bridge during high flows. When conditions did not meet the criteria for EWI sampling (usually when water depths were too shallow), a weighted bottle sampler was used to collect multiple subsamples at equal widths in the river cross section. This approach yields samples that are representative of the cross section but are not depth integrated.

Water-quality samples were processed by compositing the subsamples, filtering appropriate samples through a 0.45-micron filter, filling sample bottles, and preserving the samples. All sample processing was completed onsite and in accordance with USGS protocols and requirements outlined by the USGS National Water Quality Laboratory (NWQL) specific to the analysis being requested. Total suspendedsediment analyses were performed at the USGS Kentucky Water Science Center sediment laboratory in Louisville, Kentucky. Samples were analyzed for nutrients, major ions, and trace elements at the NWQL in Denver, Colorado (tables 2, 3). Analytical procedures used for data collected during this investigation are presented in Fishman (1993), and in Fishman and Friedman (1989) for data collected before 1989. Waterquality data collected for this investigation are presented in Appendixes 1-3.

Table 2. Analytical methods and reporting levels for nutrients and suspended sediment.

[ASF, automated segmented-flow spectrophotometry; mg/L, milligrams per liter; ${ }^{\circ} \mathrm{C}$, degrees Celsius; pre-1989 reporting levels are in parentheses]

\begin{tabular}{lll}
\hline \multicolumn{1}{c}{ Constituent } & \multicolumn{1}{c}{ Method } & Reporting level \\
\hline Ammonia plus organic nitrogen, total & Colorimetry, ASF, microkjeldahl digestion & $0.10(0.20) \mathrm{mg} / \mathrm{L}$ \\
Ammonia, filtered & Colorimetry, ASF, salicylate-hypochlorite & $0.010(0.01) \mathrm{mg} / \mathrm{L}$ \\
Nitrite plus nitrate, filtered & Colorimetry, ASF, cadmium reduction-diazotization & $0.060(0.10) \mathrm{mg} / \mathrm{L}$ \\
Nitrite, filtered & Colorimetry, ASF, low ionic-strength & $0.002(0.01) \mathrm{mg} / \mathrm{L}$ \\
Orthophosphate, filtered & Colorimetry, ASF, phosphomolybdate & $0.006(0.01) \mathrm{mg} / \mathrm{L}$ \\
Phosphorus, total & Colorimetry, ASF, microkjeldahl digestion & $0.040(0.01) \mathrm{mg} / \mathrm{L}$ \\
Total suspended sediment & Filtration, evaporation at $105{ }^{\circ} \mathrm{C}$; Gravimetric & $1(1 \mathrm{mg} / \mathrm{L}) \mathrm{mg} / \mathrm{L}$ \\
\hline
\end{tabular}


Table 3. Analytical methods and reporting levels for dissolved major ions and selected trace elements.

[mg/L, milligrams per liter; $\mu \mathrm{g} / \mathrm{L}$, micrograms per liter]

\begin{tabular}{lll}
\multicolumn{1}{c}{ Constituent } & \multicolumn{1}{c}{ Method } & Reporting level \\
\hline Calcium & Inductively coupled plasma/mass spectroscopy & $0.02 \mathrm{mg} / \mathrm{L}$ \\
Magnesium & Inductively coupled plasma/mass spectroscopy & $0.008 \mathrm{mg} / \mathrm{L}$ \\
Sodium & Inductively coupled plasma/mass spectroscopy & $0.20 \mathrm{mg} / \mathrm{L}$ \\
Chloride & Ion chromatography & $0.20 \mathrm{mg} / \mathrm{L}$ \\
Sulfate & Ion chromatography & $0.18 \mathrm{mg} / \mathrm{L}$ \\
\hline & \multicolumn{1}{c}{ Trace elements } \\
\hline Aluminum & Inductively coupled plasma/mass spectroscopy & $1.6 \mu \mathrm{g} / \mathrm{L}$ \\
Arsenic & Inductively coupled plasma/mass spectroscopy & $0.2 \mu \mathrm{g} / \mathrm{L}$ \\
Cadmium & Inductively coupled plasma/mass spectroscopy & $0.04 \mu \mathrm{g} / \mathrm{L}$ \\
Chromium & Graphite furnace atomic absorption & $0.8 \mu \mathrm{g} / \mathrm{L}$ \\
Copper & Inductively coupled plasma/mass spectroscopy & $0.4 \mu \mathrm{g} / \mathrm{L}$ \\
Iron & Inductively coupled plasma & $6 \mu \mathrm{g} / \mathrm{L}$ \\
Lead & Inductively coupled plasma/mass spectroscopy & $0.08 \mu \mathrm{g} / \mathrm{L}$ \\
Manganese & Inductively coupled plasma/mass spectroscopy & $0.6 \mu \mathrm{g} / \mathrm{L}$ \\
Mercury & Cold vapor atomic fluorescence & $0.010 \mu \mathrm{g} / \mathrm{L}$ \\
Nickel & Inductively coupled plasma/mass spectroscopy & $0.06 \mu \mathrm{g} / \mathrm{L}$ \\
\hline
\end{tabular}

\section{Load-Estimation Techniques for Data Collected during 2002-04}

Loads were calculated using LOADEST, a software program developed by the USGS (Runkel and others, 2004). The version of LOADEST used for this study fits the natural logarithm of load (concentration multiplied by streamflow) to a loglinear regression model using streamflow $(\mathrm{Q})$, linear or decimal time (dtime), and various functions of these two variables automatically up to nine parameters (table 4). Additional user-defined variables can be included. The user can select the model based on his or her knowledge of the river system or use the model automatically selected by the LOADEST program. The model is calibrated using ordinary least-squares regression, and final load estimates are derived from retransforming the logarithm of the load back to actual loads according to one of three methods-(1) the maximum likelihood estimator (MLE), (2) the adjusted maximum likelihood estimator (AMLE), or (3) the least absolute deviation (LAD; Runkel and others, 2004). LOADEST computes loads for each model by using the AMLE method and all observations in the dataset, and compares the models by using the Akaike information criterion (AIC). The model having the lowest value of the AIC statistic (representing the lowest model error) is selected for use in load estimation. Data collected during 2002-04 from the Haw and Deep Rivers were analyzed using the AMLE method, which was selected for each of the load calculations because of the ability to use censored data with

Table 4. List of regression models included in LOADEST computations.

[The natural logarithm $(\ln )$ of the load $\left(Q^{*} C\right)$ equals the following equations where $\mathrm{a}_{0}-\mathrm{a}_{6}$ equals regression coefficients, $\ln Q$ equals natural logarithm of daily discharge, and dtime equals decimal time]

\begin{tabular}{cl}
$\begin{array}{c}\text { Model } \\
\text { number }\end{array}$ & \multicolumn{1}{c}{ Regression model } \\
\hline 1 & $\mathrm{a}_{0}+\mathrm{a}_{1} \ln Q$ \\
2 & $\mathrm{a}_{0}+\mathrm{a}_{1} \ln Q+\mathrm{a}_{2} \ln Q^{2}$ \\
3 & $\mathrm{a}_{0}+\mathrm{a}_{1} \ln Q+\mathrm{a}_{2}$ dtime \\
4 & $\mathrm{a}_{0}+\mathrm{a}_{1} \ln Q+\mathrm{a}_{2} \sin (2 \pi d t i m e)+\mathrm{a}_{3} \cos (2 \pi d t i m e)$ \\
5 & $\mathrm{a}_{0}+\mathrm{a}_{1} \ln Q+\mathrm{a}_{2} \ln Q^{2}+\mathrm{a}_{3}$ dtime \\
6 & $\mathrm{a}_{0}+\mathrm{a}_{1} \ln Q+\mathrm{a}_{2} \ln Q^{2}+\mathrm{a}_{3} \sin (2 \pi$ dtime $)+\mathrm{a}_{4} \cos (2 \pi$ dtime $)$ \\
7 & $\mathrm{a}_{0}+\mathrm{a}_{1} \ln Q+\mathrm{a}_{2} \sin (2 \pi d t i m e)+\mathrm{a}_{3} \cos (2 \pi \mathrm{dtime})+\mathrm{a}_{4}$ dtime \\
8 & $\mathrm{a}_{0}+\mathrm{a}_{1} \ln Q+\mathrm{a}_{2} \ln Q^{2}+\mathrm{a}_{3} \sin (2 \pi$ dtime $)+\mathrm{a}_{4} \cos (2 \pi$ dtime $)+\mathrm{a}_{5}$ dtime \\
9 & $\mathrm{a}_{0}+\mathrm{a}_{1} \ln Q+\mathrm{a}_{2} \ln Q^{2}+\mathrm{a}_{3} \sin (2 \pi$ dtime $)+\mathrm{a}_{4} \cos (2 \pi$ dtime $)+\mathrm{a}_{5}$ dtime $+\mathrm{a}_{6}$ dtime $e^{2}$ \\
\hline
\end{tabular}


negligible bias (Cohn, 1988). For the study dataset, where at least monthly samples were available for the entire period (1976-2004), the best model selected by LOADEST was used for load calculations for both stations on the Haw and Deep Rivers. Calendar year loads for 2002 and 2003 were estimated based on the calibration period September 2002 through August 2004. The equations used to estimate loads are presented in Appendix 4.

\section{Load-Estimation Techniques for Historical Data}

Reconstruction of loads over time often is problematic because of large gaps in chemical or sediment data. Residuals (the difference between predicted and observed loads) cannot be computed for years when no data are available to calibrate the model or test the performance of the model. The question addressed in this report is whether suspended-sediment, nitrogen, and phosphorus loads changed between 1976 and 2004. In order to evaluate the effects of change, the loading models generated by using suspended-sediment data for 1976-85 and total phosphorus and total nitrogen data for 1981-85 for the Haw River near Bynum, and suspended-sediment data for 1976-83 and total phosphorus and total nitrogen data for 1981-83 for the Deep River at Moncure, and all nutrient and suspended-sediment data from both stations for 2002-04 were applied to the actual streamflow record for the entire period (1976-2004); the resulting load estimates were compared. For consistency with the statistical analysis of temporal change, described in the next section, the periods of comparison for suspended sediment are 1976-85 and 2002-04 for both stations. For hypothetical reconstruction of loads using historical streamflow data, automatic model selection by LOADEST was used for the Haw River near Bynum. In addition, loads calculated using the LOADEST program for years in which USGS data were available and reported were compared with loads calculated by previous researchers for sediment (Simmons, 1993) and for sediment, total nitrogen, and total phosphorus (Childress and Treece, 1996). All of the basic load models used for hypothetical reconstruction of annual sediment, total nitrogen, and total phosphorus loads are given in Appendix 4. The AMLE method was used as the estimation method for all models.

Historical sediment data for the Deep River at Moncure are available beginning in 1969, although the longest period of regularly collected monthly data occurred between 1981 and 1983. Some summer and fall data are available for 1976-78 and were included in the development of the model so that the total number of sediment samples was 25 for the period 1976-83. Data collected before 1976 were infrequent and appear to be event related; therefore, these data were not included. Historical data for nutrients in the Deep River at Moncure after 1980 are sparse (16 samples), and no USGS suspended-sediment or nutrient data were collected between 1984 and 2002. As a result, nutrient loads could not be computed for this site for the period 1976-83 because of insufficient data to run the LOADEST model. Because concentration and instantaneous load data for sediment were not available for almost 20 years, only flow was selected as the predictor variable (model 1, table 4) for estimating sediment loads. Sufficient sediment data were available (25 samples) to estimate loads generated from a model calibrated for the period 1976-83 for comparison with loads estimated from the model for the recent period (2002-04).

\section{Analysis of Temporal Changes}

Typical approaches to sediment and water-quality sampling for estimating loads may not allow a reliable evaluation of changes in water quality (concentration) over time using trend tests, such as simple correlation analysis or two-sample tests used to test differences between two or more time periods. Most statistical techniques for hypothesis testing require random sampling through time so that all conditions have an equal probability of being represented. The assumption of randomness usually is not entirely true for water-quality sampling where load estimation is the intended goal because either extreme low or high flows are targeted for sampling to allow the development of regression equations for predicting loads or concentrations for load-calculation purposes, thus negating the assumption of randomness for statistical hypothesis testing. A preponderance of high- or low-flow samples will bias statistics generated from such data and may not be representative of the average conditions in the environment. It was assumed for the analysis conducted for this investigation that monthly sampling with some limited, targeted samples of very high and low flows, which probably is typical of most ambient-monitoring networks, was basically suitable for statistical hypothesis testing. Because chemical water-quality data were collected by the USGS from the Haw River near Bynum primarily during the 1987-94 high flows, these data were excluded from the statistical analysis using the Mann-Whitney test (Conover, 1980).

Because loads are calculated by multiplying streamflow by nutrient concentration, loads are always correlated to flow and, thus, must be used carefully when assessing changes in magnitude through time. Decreases or increases in load may be a result of either corresponding decreases or increases in streamflow or nutrient concentrations. For this reason, trends in streamflow, loads, and nutrient concentrations were evaluated separately.

For this report, trends in flow and concentration were considered suitable for evaluation (1) if regularly collected data (for example, monthly) were available for the period of record without a large number of targeted high or low flows, and (2) by applying a nonparametric Spearman's rho correlation test (Conover, 1980) to daily flow or monthly concentrations of total nitrogen, total phosphorus, and suspended sediment with time. The hypotheses being tested for positive or negative trend with a correlation analysis are as follows: 
(1) $\mathrm{H}_{0}$ - The paired time and nutrient concentrations through the period of record are mutually independent and not correlated (null hypothesis).

(2) $\mathrm{H}_{1}$ - (a) Larger values of concentration (or load) tend to be paired with larger values of time (increasing trend or positive correlation), or (b) smaller values of concentration (or load) tend to be paired with larger values of time (decreasing trend or inverse correlation; alternative hypothesis).

The Spearman's rho correlation coefficient is calculated by using ranks of the raw data. A correlation of 1 or -1 indicates a perfect correlation or inverse correlation between two variables, and a zero indicates no correlation. For this report, a trend was considered significant if the p-value generated by the test was less than $(<) 0.05$ (that is, the significance level, or $\alpha$, was 0.05 ).

If data are not available over time to test for monotonic trend with a Spearman's rho or some other test, it may be possible to test differences in concentrations or loads for the two time periods being compared. If regularly collected data can be assumed to be basically random throughout the period (or periods) of record, a two-sample nonparametric MannWhitney test (Conover, 1980) can be applied to the datasets to test the following:

(3) $\mathrm{H}_{0}$ - There is no difference in concentrations (or loads) between the two periods.

(4) $\mathrm{H}_{1}$ - The concentrations (or loads) between the two periods are not identical.

It may be possible to divide the data into a before and after period, in which the approximate midpoint of a continuous period of record (for example, for the period 1990-2000, the midpoint is 1995), can be used to split the data for statistical comparison. Alternatively, when data are available for two separate periods, with no or inadequate data available for the period between (for example, 1980-85 and 2000-03), the Mann-Whitney test can be applied to determine if water-quality conditions are different. For this report, the significance level of 5 percent $(\alpha=0.05)$ was adopted so that values of $\mathrm{p}<0.05$ were considered statistically significant and the null hypothesis (3) was rejected. In addition to the data collected by the USGS at the sites, total suspended solids, total nitrogen, and total phosphorus data collected by the NCDWQ also were compared in selected cases to verify conclusions about trends indicated by the USGS data or to evaluate possible differences in information conveyed about concentrations or trends by the two datasets.

\section{Streamflow, Suspended Sediment, and Nutrient Concentrations and Loads in the Upper Cape Fear River Basin, 2002-04}

Sample collection began in August 2002 and ended in August 2004. Sampling occurred during unusually dry and wet years compared to the long-term record at both sites. The median streamflows for the Haw River near Bynum for water years ${ }^{\mathrm{c}} 2002,2003$, and 2004 were 169, 1,700, and 636 cubic feet per second ( $\mathrm{ft}^{3} / \mathrm{s}$ ), respectively (table 5 ; fig. 2). The median streamflow for this site from 1976 through 2002 was $570 \mathrm{ft}^{3} / \mathrm{s}$ (table 5). Based on available streamflow information (Ragland and others, 2003, 2004; Walters and others, 2005) water years 2002, 2003, and 2004 were very dry, very wet, and about average, respectively. The streamflow patterns at the Deep River at Moncure were similar to those of the Haw River (fig. 2). The median streamflows for the Deep River for water years 2002, 2003, and 2004 were 101, 1,430, and $542 \mathrm{ft}^{3} / \mathrm{s}$, respectively. The 1976-2004 median flow for the Deep River was $512 \mathrm{ft}^{3} / \mathrm{s}$ (table 5; fig. 2).

Annual streamflow variation can have several effects on water quality. For nutrients that are derived from continuous

\footnotetext{
${ }^{c}$ Water year is the period from October 1 through September 30 and is identified by the year in which the period ends. For example, the 2002 water year began October 1, 2001, and ended September 30, 2002.
}

Table 5. Selected streamflow statistics for the Haw River near Bynum and the Deep River at Moncure, North Carolina.

\begin{tabular}{|c|c|c|c|c|}
\hline $\begin{array}{c}\text { Streamflow, } \\
\text { in cubic feet } \\
\text { per second }\end{array}$ & $\begin{array}{c}\text { Water years } \\
\text { 1976-2004 }\end{array}$ & $\begin{array}{c}\text { Water year } \\
2002\end{array}$ & $\begin{array}{l}\text { Water year } \\
2003\end{array}$ & $\begin{array}{c}\text { Water year } \\
2004\end{array}$ \\
\hline \multicolumn{5}{|c|}{ Haw River near Bynum } \\
\hline Minimum & 0.18 & 60 & 106 & 174 \\
\hline Mean & 1,259 & 370 & 2,950 & 938 \\
\hline Median & 570 & 169 & 1,700 & 636 \\
\hline Maximum & 58,000 & 6,900 & 33,300 & 10,700 \\
\hline Number of values & 10,593 & 365 & 365 & 366 \\
\hline \multicolumn{5}{|c|}{ Deep River at Moncure } \\
\hline Minimum & 18 & 22 & 37 & 105 \\
\hline Mean & 1,426 & 391 & 3000 & 1,020 \\
\hline Median & 512 & 101 & 1,430 & 542 \\
\hline Maximum & 36,800 & 11,500 & 29,000 & 13,000 \\
\hline Number of values & 10593 & 365 & 365 & 366 \\
\hline
\end{tabular}



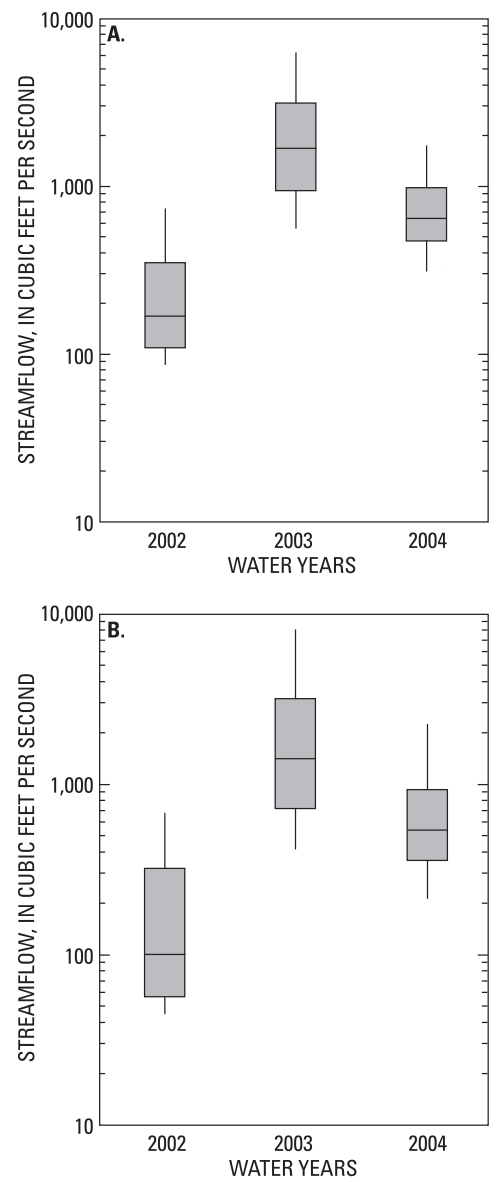

Figure 2. Streamflow in the (A) Haw River near Bynum and (B) Deep River at Moncure, North Carolina, for water years 2002-04.

discharge sources (point-source discharges or contaminated ground water), the concentrations generally will be higher (having potential short-term biological effects), and the loads will be lower during dry years. Conversely, nutrient concentrations generally will be lower and the loads will be higher during wet years. For nutrients and sediment derived from diffuse or nonpoint sources associated with runoff, both concentrations and loads generally will be lowest during dry years and highest during wet years.

Five water-quality samples per year were collected at both sites for 2 years and analyzed for selected major ions and trace elements to characterize general water quality in the Haw and Deep Rivers. The analytical results for these samples are given in Appendix 3A (Haw River) and 3B (Deep River). Because of the small number (10) of samples collected during this investigation, reliable load estimates for these constituents could not be made. In general, the water types of the Haw and Deep Rivers are similar and have the same overall characteristics - a mixed ionic water type (calcium-magnesium-sodiumpotassium-bicarbonate-sulfate-chloride). Calcium was the dominant cation during high flows, which typically occurred during the winter and spring months, and sodium was the dominant cation during low flows, which typically occurred during the summer and fall months (fig. 3). As noted in Childress and Treece (1996), the dominant water types for streams affected by point sources in the study area are sodium plus potassium and sulfate, whereas streams minimally affected by point sources have a calcium and bicarbonate-dominated water type. From the trace element data (Appendix 3A, B), no dissolved constituent concentrations were measured that exceeded current (2004) water-quality standards for drinking water or aquatic life established by either the NCDWQ or the U.S. Environmental Protection Agency (USEPA).

\section{Nutrient and Suspended-Sediment Concentrations}

Nutrient and suspended-sediment samples were collected from the Haw and Deep Rivers over a 2-year period, beginning in August 2002 and ending in August 2004 (table 6). Median concentrations of total nitrogen and ionic forms of nitrogen and suspended sediment appear to be similar at both sites and are not significantly different (p greater than $(>) 0.05$ ). On the other hand, orthophosphate and total phosphorus concentrations in water samples from the Deep River were significantly $(\mathrm{p}<0.05)$ higher. This difference can be seen more clearly in the box plots shown in figure 4 , where the difference in total phosphorus concentrations between the two sites is more apparent than the differences in total nitrogen and suspendedsediment concentrations.

Seasonal concentrations of suspended sediment, orthophosphate, and total nitrogen varied (fig. 5). (Orthophosphate was the only form of phosphorus available during the period 2002-04 and is included here for comparison of the effects of the very dry summer in 2002.) Suspended-sediment concentrations, except during spring and summer 2003, tended not to vary greatly from one season to the next. The occurrences of relatively high concentrations of suspended sediment during the high flows of the unusually wet spring and summer of 2003 (fig. 5) are indicative of nonpoint sources (for example, erosion from hillsides or banks). Concentrations of total nitrogen and orthophosphate were higher during the 2002 and 2004 summers, previously noted as dry to average years, and lower during 2003. This generally indicates the influence of continuous discharge (wastewater from point sources or ground water) on nutrient concentrations, particularly during low flows.

Wastewater is a continuous source of both nitrogen and phosphorus concentrations in the Haw and Deep Rivers, and substantially higher orthophosphate concentrations occurred in the Deep River during all seasons (fig. 5). This finding is consistent with information presented by the North Carolina Department of Environment and Natural Resources (2004). Very high (median > 1.5 milligrams per liter $(\mathrm{mg} / \mathrm{L})$ ) concentrations of total phosphorus occurred between 1998 and 2003 in the Deep River near High Point, NC, and remained high downstream at Ramseur (North Carolina Department of 
A.

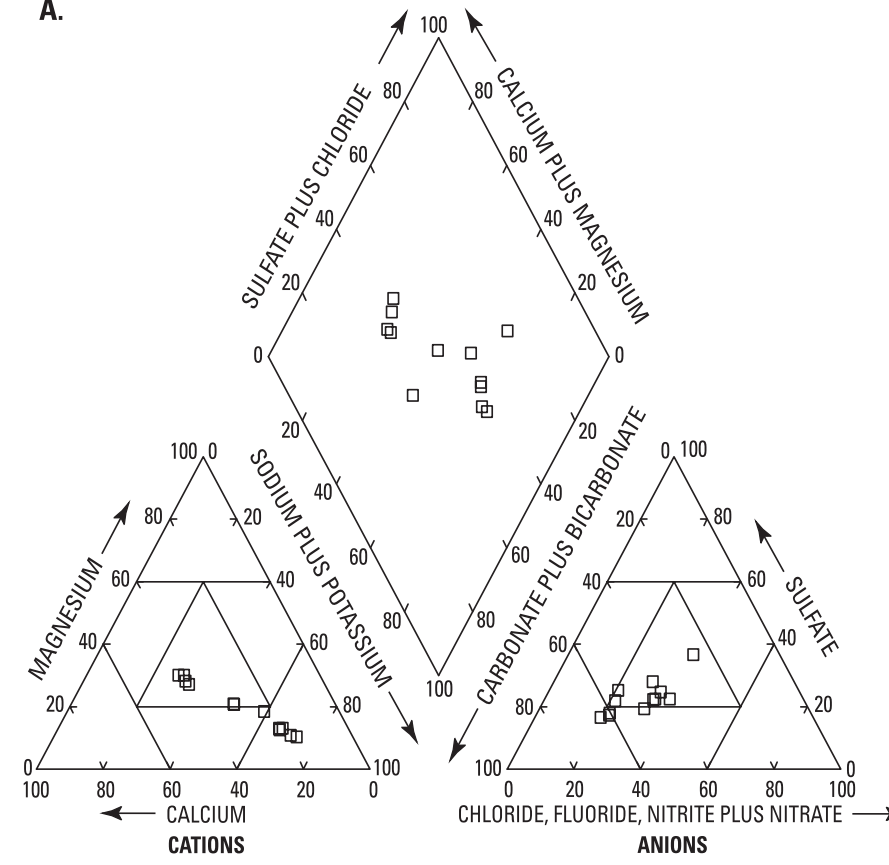

B.

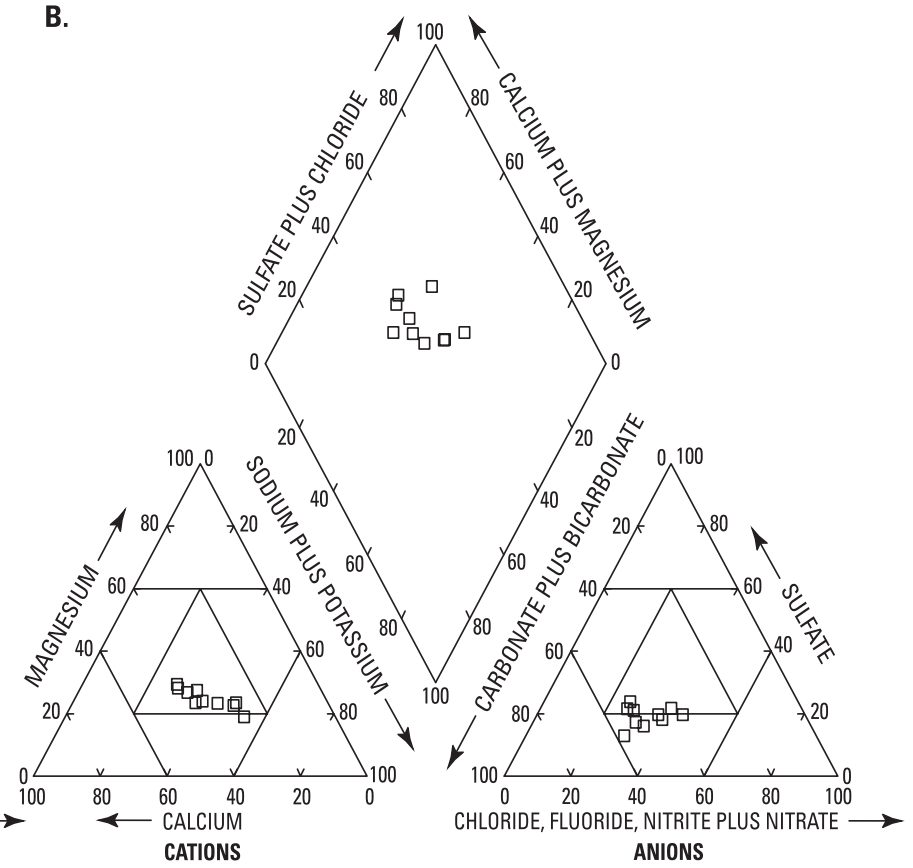

Figure 3. Water types for the (A) Haw River near Bynum and (B) Deep River at Moncure, North Carolina, $2002-04$.

Table 6. Statistical summary of nutrient and suspended-sediment concentrations in the Haw and Deep Rivers, North Carolina, 2002-04.

[+, plus; all values are in milligrams per liter. At each sampling site, 86 values were used to compute statistics for suspended sediment and for each nutrient shown]

\begin{tabular}{|c|c|c|c|c|c|c|c|c|}
\hline \multicolumn{9}{|c|}{ Haw River near Bynum } \\
\hline Mean & 0.047 & 0.66 & 0.91 & 0.010 & 1.6 & 0.092 & 0.16 & 36 \\
\hline Median & 0.031 & 0.60 & 0.75 & 0.0075 & 1.4 & 0.067 & 0.13 & 14 \\
\hline Maximum & 0.40 & 1.7 & 3.5 & 0.044 & 4.5 & 0.46 & 0.44 & 350 \\
\hline \multicolumn{9}{|c|}{ Deep River at Moncure } \\
\hline Maximum & 0.405 & 2.7 & 2.14 & 0.028 & 3.9 & 0.81 & 0.54 & 468 \\
\hline
\end{tabular}



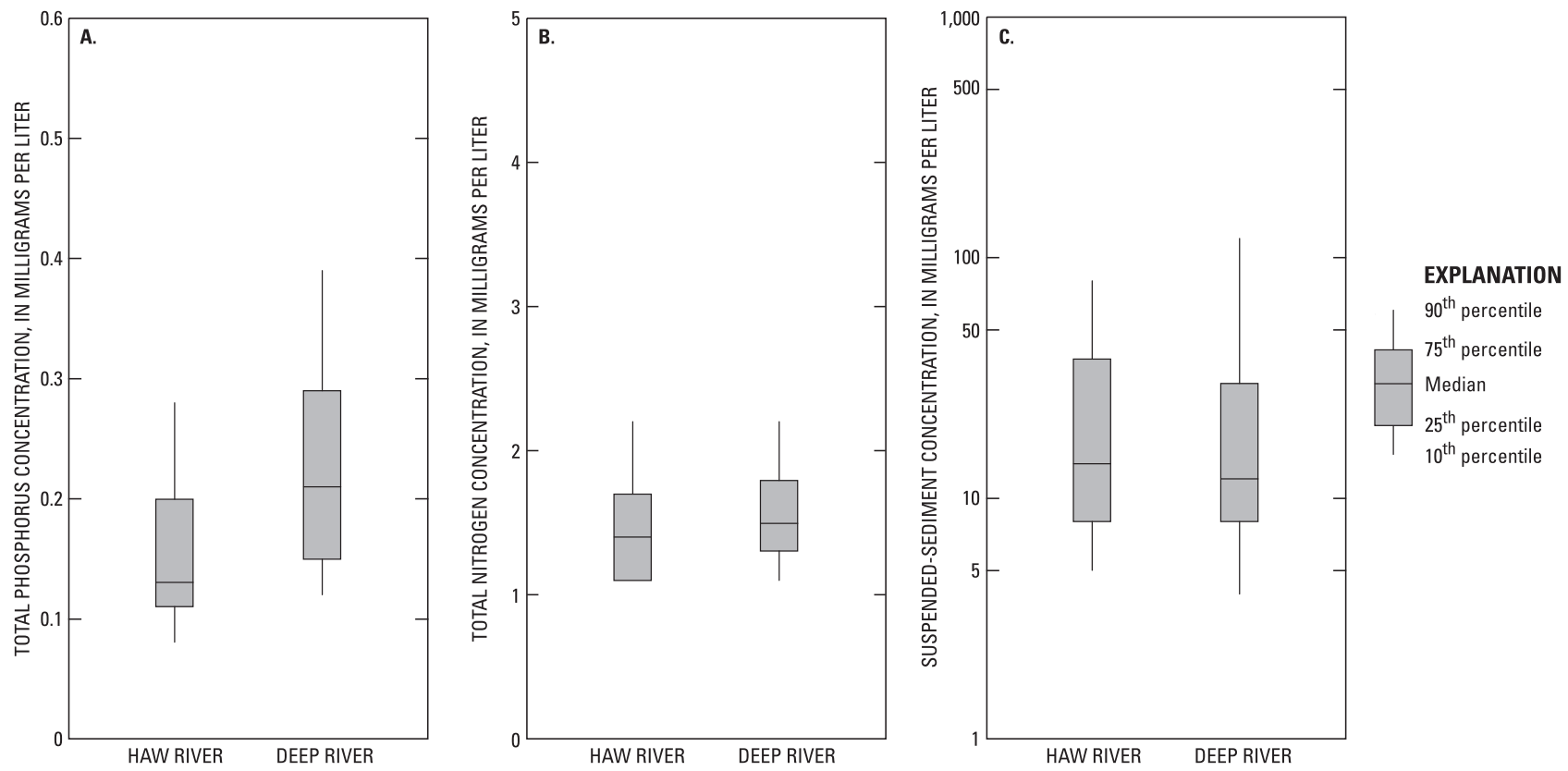

Figure 4. (A) Total phosphorus, (B) total nitrogen, and (C) suspended-sediment concentrations in the Haw River near Bynum and the Deep River at Moncure, North Carolina, 2002-04.

Environment and Natural Resources, 2004). Total phosphorus concentrations decreased to about $0.15 \mathrm{mg} / \mathrm{L}$ downstream from Ramseur but increased again to above $0.2 \mathrm{mg} / \mathrm{L}$ at the NCDWQ monitoring station near Sanford, NC, and remained at this concentration at the NCDWQ monitoring station farther downstream at Moncure. In the Haw River, total phosphorus concentrations were much lower; the median total phosphorus concentration ranged from about $0.1 \mathrm{mg} / \mathrm{L}$ in the upper reaches to about $0.25 \mathrm{mg} / \mathrm{L}$ at the NCDWQ monitoring station near Burlington, $\mathrm{NC}$, and decreased to about $0.17 \mathrm{mg} / \mathrm{L}$ at the monitoring station near Bynum (North Carolina Department of Environment and Natural Resources, 2004).

Anthropogenic sources of nutrients and sediment affect water quality, but a greater overall effect was observed in the Deep River. Both the Haw and Deep Rivers had concentrations of suspended sediment, total nitrogen, and total phosphorus above estimated background concentrations- those that would occur in piedmont streams draining undeveloped forested watersheds. Based on the median concentrations presented for the Haw River near Bynum (table 6) and estimated background concentrations of about $0.5 \mathrm{mg} / \mathrm{L}$ for total nitrogen and $0.05 \mathrm{mg} / \mathrm{L}$ for phosphorus reported by Simmons and Heath (1982) for streams draining the study area in the Piedmont Physiographic Province, 50 percent of the nitrogen ( 2 times the background) and more than 66 percent of the phosphorus (3 times the background) concentrations are derived from anthropogenic sources. The median concentration of suspended sediment in the Haw River near Bynum ( $14 \mathrm{mg} / \mathrm{L}$, table 6 ) approximated about 2 to 3 times the median suspended-sediment concentration $(5-6 \mathrm{mg} / \mathrm{L})$ reported by Simmons (1993) for piedmont forested watersheds (assumed to represent background or pre-development conditions). Stated another way, anthropogenic sources currently (2004) compose about 50-66 percent of the sediment load in the Haw River.

For the Deep River at Moncure, the median concentrations of total nitrogen and total phosphorus (table 6) were approximately 3 times the background total nitrogen and more than 4 times the background total phosphorus concentrations reported by Simmons and Heath (1982) — higher nutrient enrichment than observed in the Haw River. Based on information presented in Simmons (1993), the median suspended-sediment concentration in the Deep River at Moncure (12 mg/L, table 6) approximated about 2 times that reported for piedmont forested watersheds $(5-6 \mathrm{mg} / \mathrm{L})$. Possible reasons for these differences are discussed at the end of the next section. 

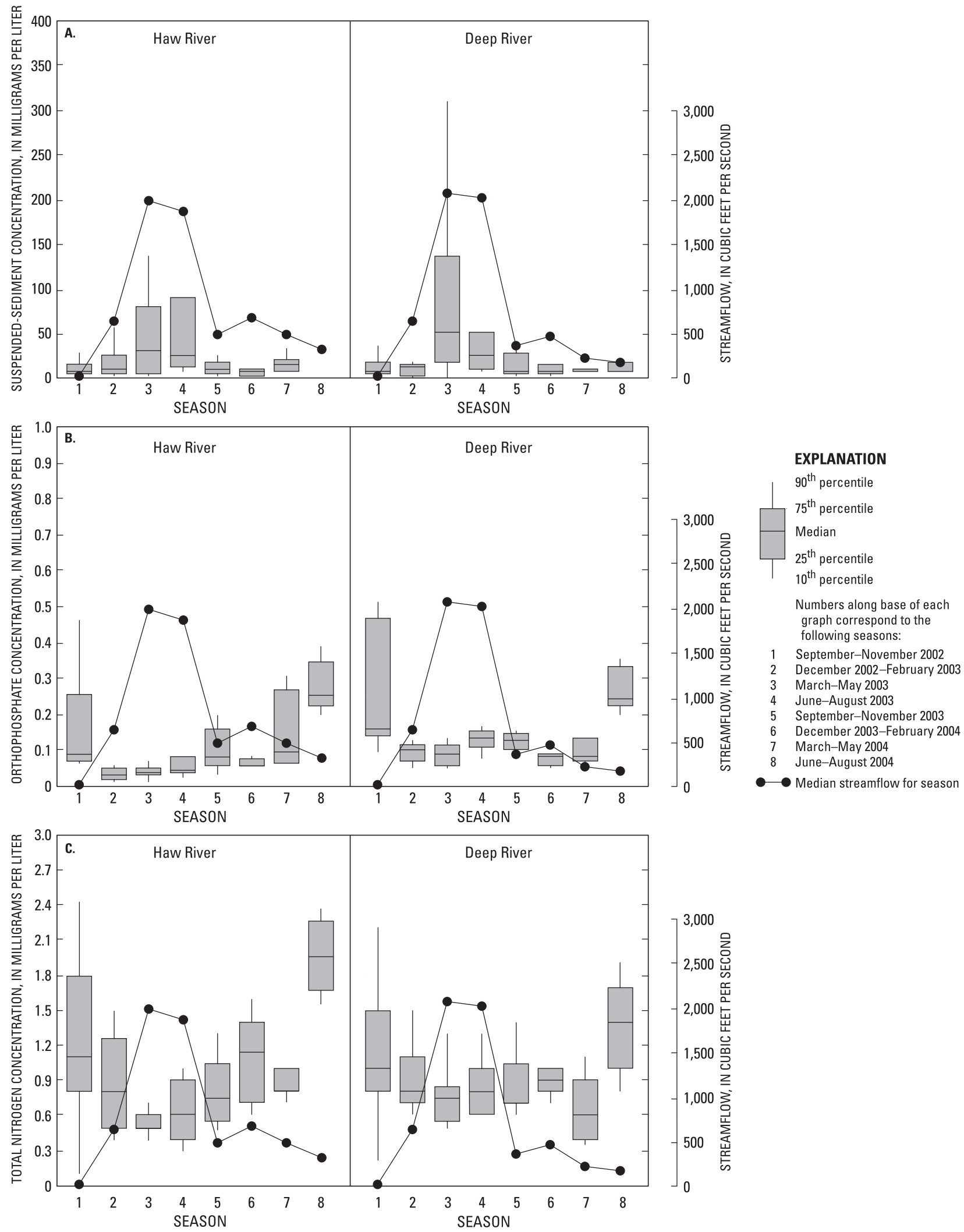

Figure 5. Seasonal concentrations of (A) suspended sediment, (B) orthophosphate, and (C) total nitrogen in the Haw River near Bynum and the Deep River at Moncure, North Carolina, 2002-04. 


\section{Nutrient and Suspended-Sediment Loads}

Loads of total nitrogen, total phosphorus, and suspended sediment in the Haw and Deep Rivers were estimated for the 2002 and 2003 calendar years and seasonally for the period 2002-04. Seasons are represented by quarters, using 3-month intervals beginning September 2002 and ending in August 2004. The transport equations used to estimate loads are given in Appendix 4.

\section{Annual Loads}

During the 2002 calendar year, the Haw River near Bynum transported 1,400 tons of total nitrogen, 160 tons of total phosphorus, and 56,000 tons of suspended sediment (table 7). In 2003, the river transported 3,400 tons of total nitrogen, 470 tons of total phosphorus, and 230,000 tons of suspended sediment. The yields for total nitrogen were 1.1 tons per year per square mile (tons/yr)/ $\mathrm{mi}^{2}$ in 2002 and

Table 7. Nutrient and sediment loads and yields in the Haw and Deep Rivers, North Carolina, for calendar years 2002 and 2003.

[\%, percent; tons/yr, tons per year; (tons/yr) $/ \mathrm{mi}^{2}$, tons per year per square mile; +, plus]

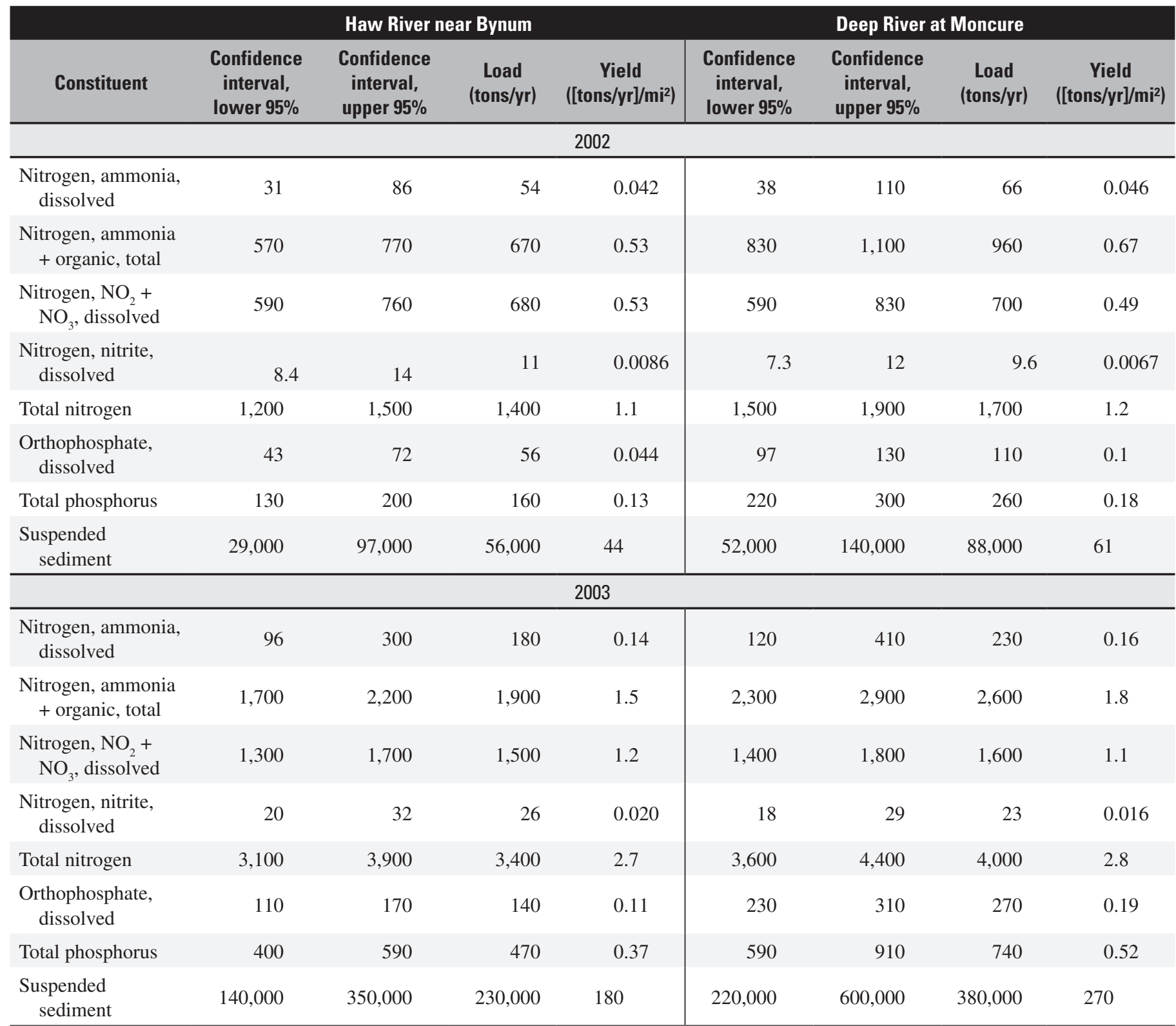


2.7 (tons $/ \mathrm{yr}) / \mathrm{mi}^{2}$ in 2003 . Total phosphorus yields were 0.13 (ton/yr)/mi ${ }^{2}$ in 2002 and 0.37 (ton/yr) $/ \mathrm{mi}^{2}$ in 2003. Suspended-sediment yields were 44 (tons $/ \mathrm{yr}$ ) $/ \mathrm{mi}^{2}$ in 2002 and 180 (tons/yr)/mi² in 2003 (table 7).

The Deep River at Moncure transported 1,700 tons of total nitrogen, 260 tons of total phosphorus, and 88,000 tons of suspended sediment during the 2002 calendar year. In 2003, the river transported 4,000 tons of total nitrogen, 740 tons of total phosphorus, and 380,000 tons of suspended sediment. The yields for total nitrogen were 1.2 (tons $/ \mathrm{yr}$ ) $/ \mathrm{mi}^{2}$ in 2002 and 2.8 (tons $/ \mathrm{yr}$ ) $/ \mathrm{mi}^{2}$ in 2003 . The yields for total phosphorus were 0.18 (ton/yr)/mi ${ }^{2}$ in 2002 and 0.52 (ton/yr)/ $\mathrm{mi}^{2}$ in 2003. Suspended-sediment yields were 61 (tons $/ \mathrm{yr}$ )/ $\mathrm{mi}^{2}$ in 2002 and 270 (tons $/ \mathrm{yr}$ )/ $\mathrm{mi}^{2}$ in 2003 (table 7). The loads of all chemical constituents at each site were significantly higher in 2003 than in 2002, primarily because of the much higher flows during 2003 (fig. 2).

Comparison among sites can be accomplished by evaluating yields, which normalize for differences in drainage area. Yields of total nitrogen, total phosphorus, and suspended sediment generally were higher in the Deep River than in the Haw River (table 7), and yields of orthophosphate, total phosphorus, and sediment were substantially higher during the study period. These differences are the result primarily of lower concentrations in the Haw River, even though the Haw River had higher streamflows (fig. 2). It is not known why the Haw River had generally lower annual yields for nutrients and sediment than the Deep River, given that the Haw River subbasin has more developed and cultivated land and less forested land than the Deep River subbasin (table 1A). The Haw River also is permitted for a total effluent discharge of about $93 \mathrm{Mgal} / \mathrm{d}$ compared with $53 \mathrm{Mgal} / \mathrm{d}$ in the Deep River (North Carolina Division of Water Quality, 2005b). Based on this information, one might expect poorer water quality in the Haw River, although this is not supported by the data presented in this report. Because the Haw River is classified as Nutrient Sensitive Water by the NCDWQ, however, point-source dischargers along the Haw River are under more stringent discharge limits, particularly in regard to phosphorus, than along the Deep River (Michelle Woolfolk, North Carolina Division of Water Quality, oral commun., April 2005); this appears to be a major factor in accounting for lower phosphorus concentrations in the Haw River. Even though the Haw River subbasin has more people, developed lands, and cultivated lands than the Deep River subbasin, the Deep River subbasin above Moncure has 6 times as many swine and 5.5 times as many poultry (table 1B), which are major potential sources of nutrients in watersheds (Mallin, 2000). Another factor that may contribute to water-quality differences between the two subbasins is the number of impoundments along the two rivers-the Haw River has 59 and the Deep River has 34 (Tammy Idol, North Carolina Division of Land Resources, written commun., 2005). Additional studies that focus on why some of these water-quality differences exist could provide valuable information for future management of the upper Cape Fear River basin.

\section{Seasonal Loads}

Nutrient and suspended-sediment loads were computed seasonally for the Haw River near Bynum and the Deep River at Moncure. The seasons were divided into spring, summer, fall, and winter, and each season was composed of a 3-month period beginning in September 2002 and ending in August 2004 for a total of eight seasons.

The highest loads estimated for the Haw River during this period were 1,500 tons of total nitrogen, 234 tons of total phosphorus, and 140,000 tons of suspended sediment, all of which occurred during spring 2003 (table 8). The lowest loads transported in the Haw River during the period were 240 tons of total nitrogen, 26 tons of total phosphorus, and 3,100 tons of suspended sediment. The lowest total phosphorus and suspended-sediment loads occurred in spring 2004, and the lowest total nitrogen load occurred in summer 2004 (table 8).

The highest loads in the Deep River during this investigation also occurred in spring 2003 for all constituents1,800 tons of total nitrogen, 436 tons of total phosphorus, and 260,000 tons of suspended sediment. The lowest loads transported in the Deep River during this period were 240 tons of total nitrogen, 33 tons of total phosphorus, and 6,700 tons of suspended sediment. The lowest range of loads during the study occurred in spring 2004 for suspended sediment and in summer 2004 for total phosphorus and total nitrogen (table 8).

During this investigation, loads of all constituents at both sites were greatest during the spring and summer 2003, an unusually wet year with a very wet spring and summer, and lowest during the fall and winter months (fig. 6). During 2004, a more typical year hydrologically, primary transport of nutrient and sediment loads occurred during the fall and winter months. Because water year 2003 was much wetter than water year 2004, substantially greater loads were transported during the first four seasons than during the last four at both sites. Both sites had the largest loads of all constituents transported during spring 2003 (table 8). 
Table 8. Seasonal loads of nutrients and suspended sediment in the Haw River near Bynum and the Deep River at Moncure, North Carolina, during September 2002-August 2004.

$[+$, plus; all values are in tons $]$

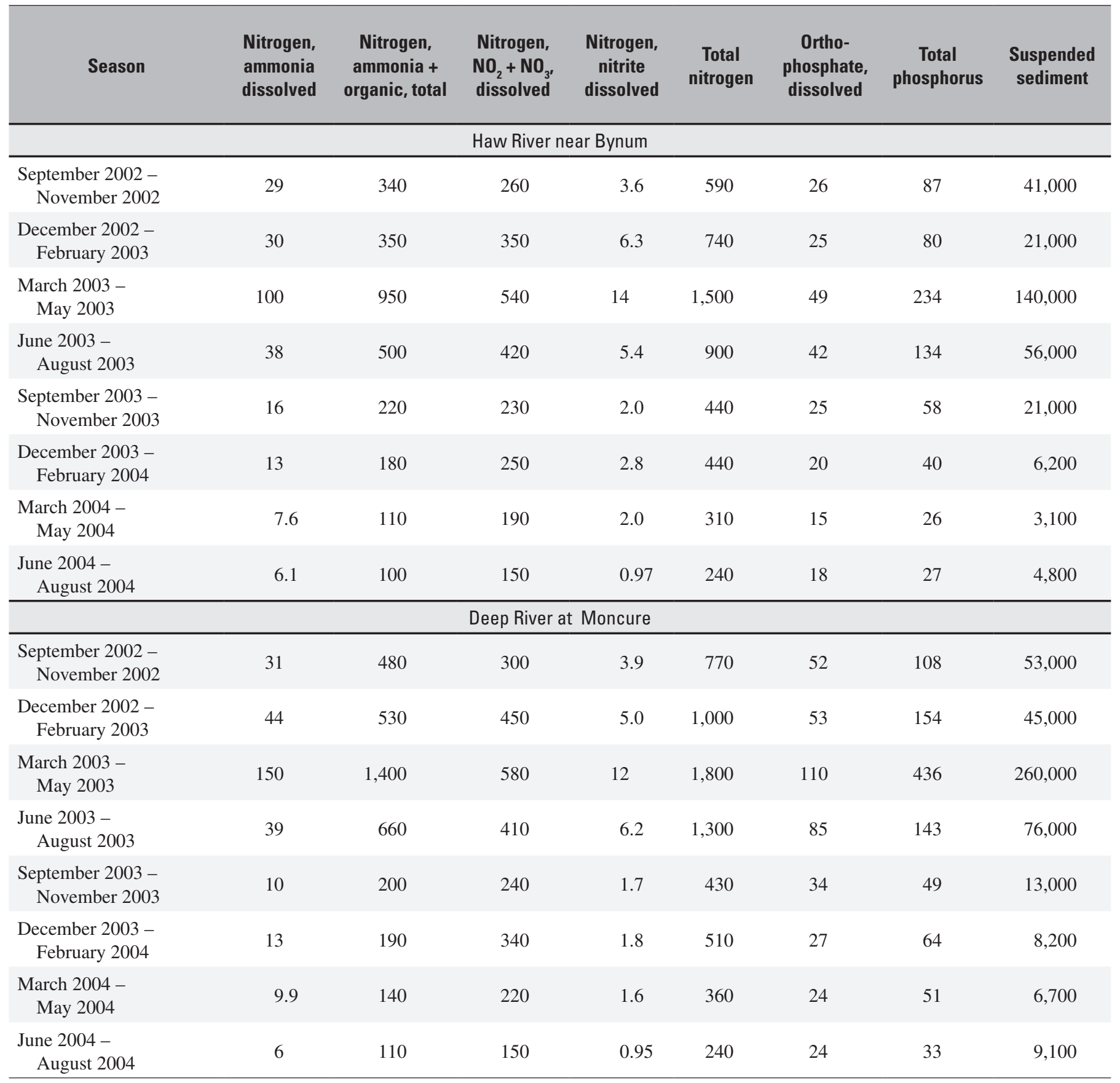



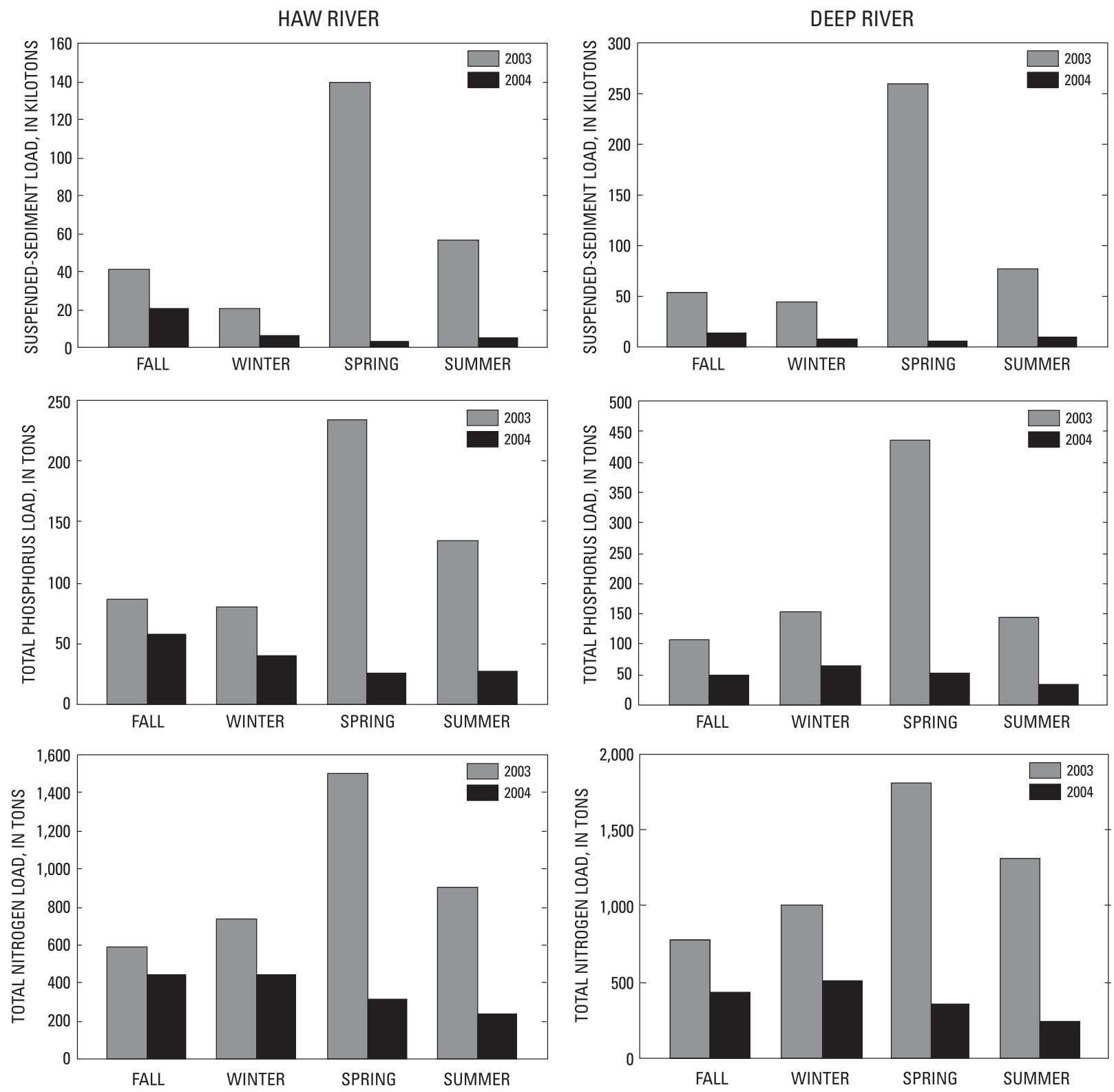

Figure 6. Seasonal loads of suspended sediment, total phosphorus, and total nitrogen in the Haw River near Bynum and the Deep River at Moncure, North Carolina, for water years 2003 and 2004.

\section{Historical Changes in Streamflow, Suspended-Sediment, and Nutrient Concentrations and Loads, 1976-2004}

Although continuous streamflow data are available from the USGS for the Haw River near Bynum since 1973 and for the Deep River at Moncure since 1930, the availability of water-quality data from the USGS at these sites is more limited. The utility of long-term water-quality and streamflow data is that environmental effects of changes in land use or management practices on water quality can be evaluated throughout the period for which data are available. Regularly collected (monthly to quarterly) suspended-sediment data are available for the Haw and Deep River sites beginning in 1976, although substantially fewer analyses are available for the Deep River at Moncure. Regularly collected total nitrogen and total phosphorus data for the Haw and Deep Rivers are available from 1981 .

The general time period between 1976 and 2004 was considered to be appropriate for comparing changes in water quality, particularly in light of 25-30 years of changes in land use and population, improvements in wastewater-treatment plants, regulations banning phosphorus in detergents in 1988 (Childress and Treece, 1996), implementation of nonpointsource controls as best-management practices, changes in planted agricultural acreage, and other major changes. The 
approximate midpoint of this period is 1990 , which formed the primary division of data for two-sample comparisons of change or for calibration of data between the time periods compared in this report.

The analysis presented here attempts to answer the question of whether water quality has changed in the Haw River near Bynum or in the Deep River at Moncure since 1976. Possible trends or changes in concentrations through time were evaluated by statistically examining streamflow, total nitrogen, total phosphorus, and suspended-sediment concentrations and loads for the period 1976-2004 for sediment and for the period 1981-2004 for total nitrogen and total phosphorus, using trend-detection techniques as described previously. It is intended that this analysis also will provide a baseline for measuring possible future changes.

\section{Streamflow in the Haw River near Bynum}

Using annual streamflows in the Haw River near Bynum for the period 1976-2004 (fig. 7), a slight, but significant decrease in mean daily streamflow was detected using Spearman's rho $(\rho=-0.04, p<0.05)$. Based on the information shown in figure 7 , streamflows were among the lowest in 2002 (similar to those during the late 1980s) and among the highest in 2003 when water-quality samples were collected as part of this investigation. A wide range of flows, therefore, is represented in the water-quality samples collected during 2002-04. Even though a significant negative trend in streamflow was detected at the Haw River near Bynum for the period 1976-2004, it was very small ( $p<-0.05$ ). This slight longterm trend is assumed to have no discernible effect on water quality. Therefore, a general assumption for trend analysis is that any trend in concentration or load at this site is not related to a trend in streamflow; thus, some other factor is assumed to be responsible for the observed water-quality trend.

\section{Suspended Sediment in the Haw River near Bynum}

Suspended-sediment concentration data for the Haw River near Bynum are available from the USGS for the period 1976-94, collected at approximately monthly intervals during 1978-79 and from 1981 to 1985 , monthly during 1988-89, and quarterly between 1992 and 1994. One sample was collected in 1998. Only high flows were sampled for sediment between 1988 and 1998. These data are not suitable for trend analysis of concentrations, however, because low to moderate flows were not represented during these years. Samples were collected weekly to biweekly as part of this study between 2002 and 2004. Monthly data for total suspended solids also

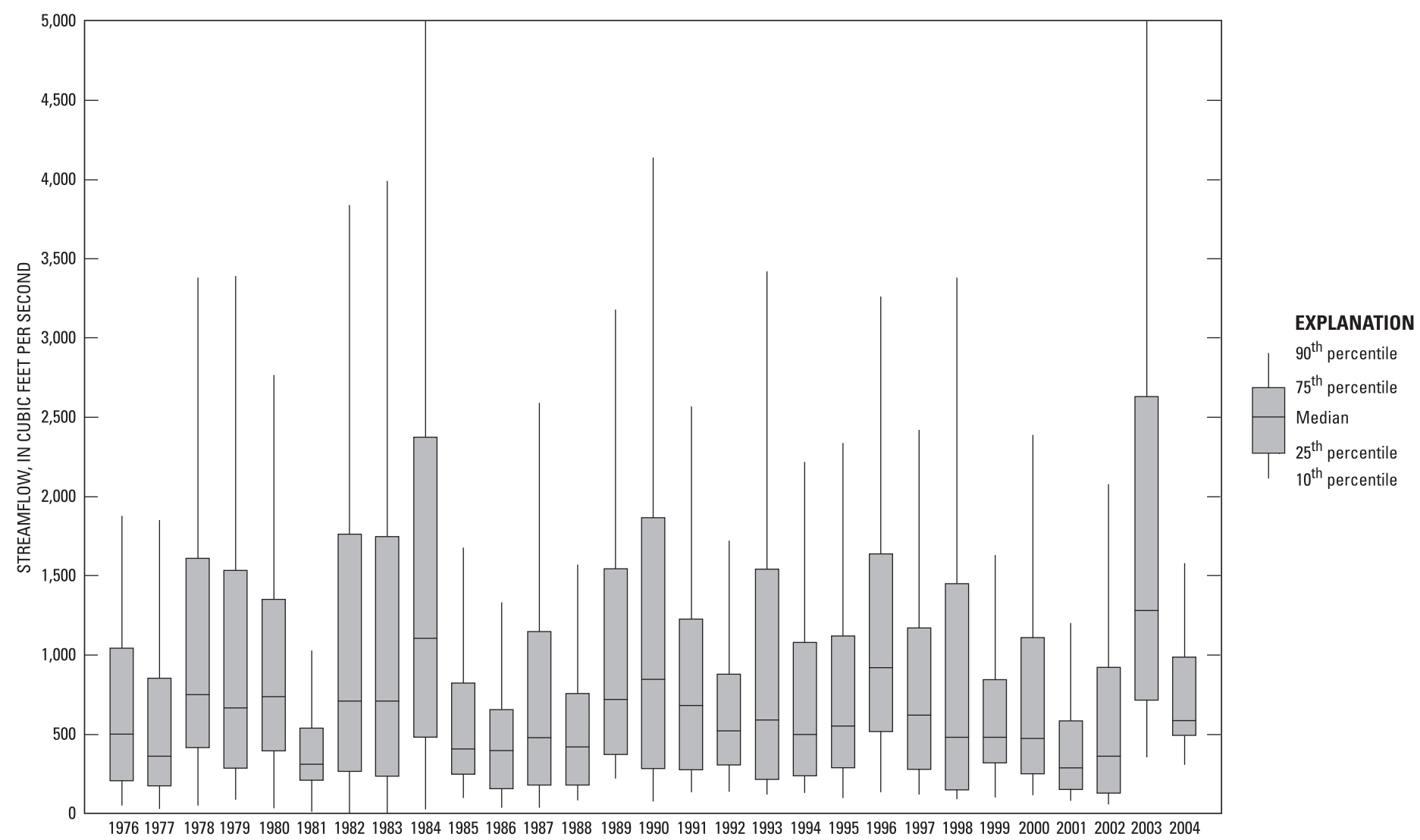

Figure 7. Annual streamflow in the Haw River near Bynum, North Carolina, 1976-2004. 
are available from the NCDWQ for 1980-2004. Because the NCDWQ data were collected monthly through the period, these data are suitable for either analysis of monotonic trend or a before and after analysis using a two-sample test. The relations of NCDWQ total suspended-solids data and USGS suspended-sediment data to streamflow data collected by the USGS are shown in figure 8, which indicates a similar positive correlation with streamflow and good comparability at this site. In general, however, total suspended-solids data are not considered to be a suitable measure of suspended material in open-channel environments because of negative or low bias-total suspended-solids and suspended-sediment data from natural waters are not comparable and should not be used interchangeably (Gray and others, 2000). It was assumed, however, that a low bias may not necessarily affect the occur-

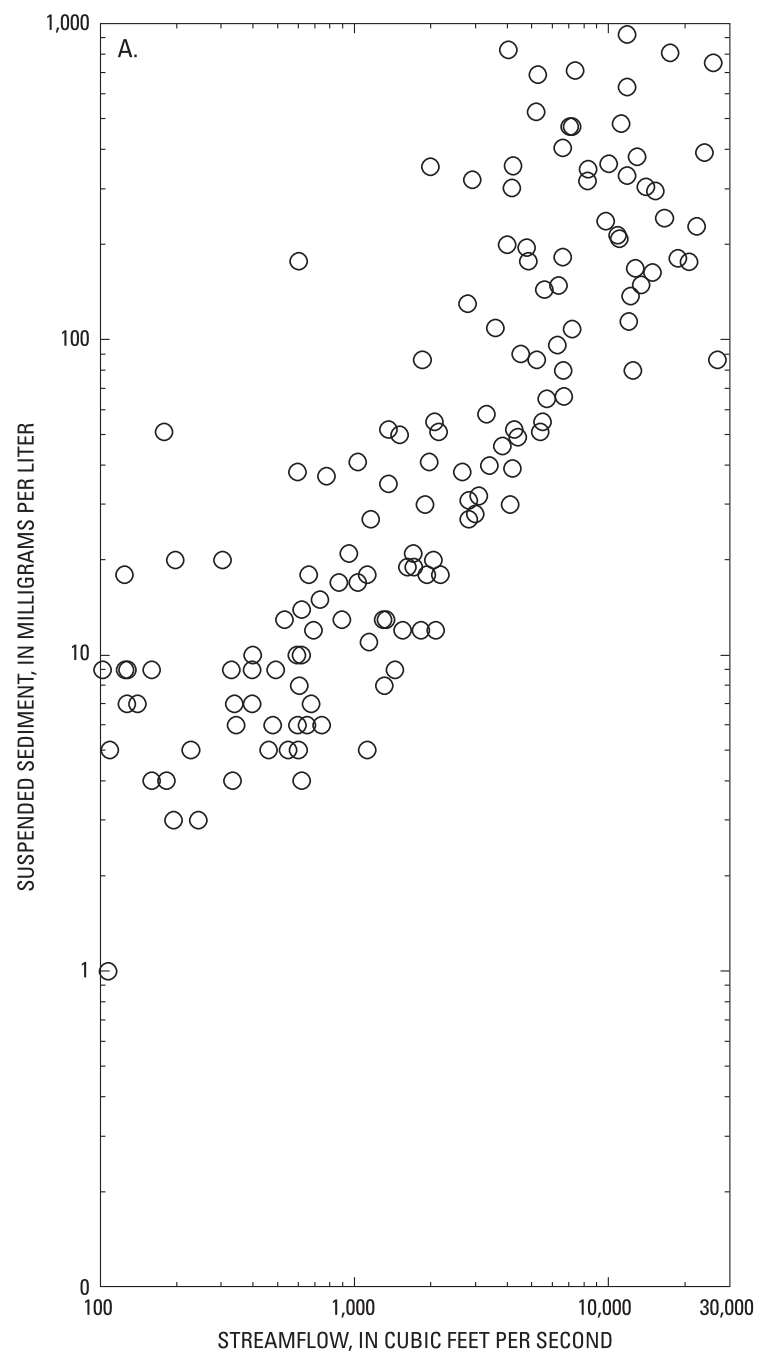

rence of possible time trends and that total suspended-solids data may be useful for trend comparisons.

A Mann-Whitney test (Conover, 1980) was applied to test for differences in suspended-sediment concentration between the 1976-85 data and the 2002-04 data from the USGS.

Data collected between 1988 and 1998 were not suitable for inclusion in the analysis, as indicated previously. Suspendedsediment concentrations have decreased significantly ( $\mathrm{p}<0.004$ ) since the early 1980s from a median of $40 \mathrm{mg} / \mathrm{L}$ to $14 \mathrm{mg} / \mathrm{L}$ during 2002-04 (fig. 9A). This decrease in suspended-sediment concentration is parallel to a significant decrease $(\mathrm{p}<0.0001)$ in total suspended-solids concentration from a median of $10 \mathrm{mg} / \mathrm{L}$ to $7 \mathrm{mg} / \mathrm{L}$ (fig. 9B). Because suspended sediment is highly correlated to streamflow, the decrease in concentrations could be attributed to flow differences alone if streamflows were different between the two

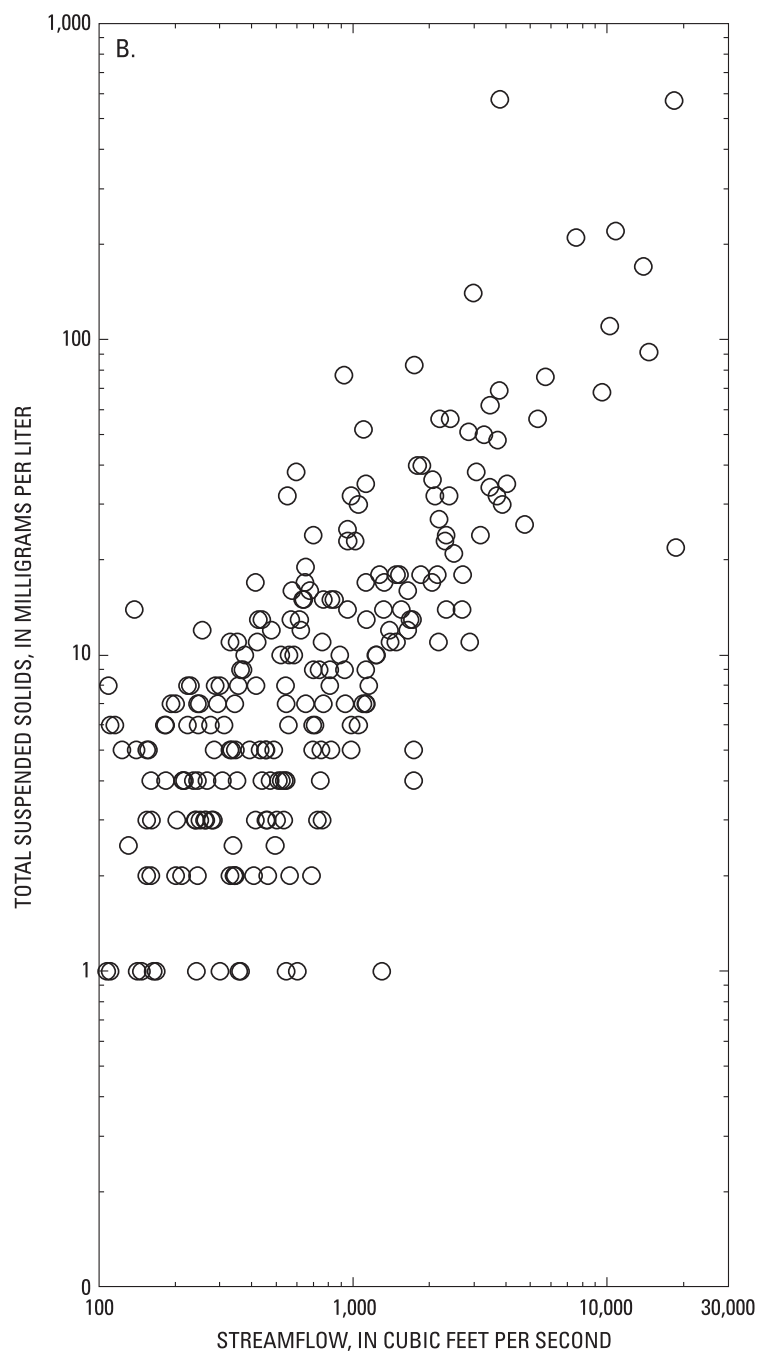

Figure 8. Relation of (A) suspended-sediment data collected by the U.S. Geological Survey and (B) total suspended-solids data collected by the North Carolina Division of Water Quality to streamflow at the Haw River near Bynum, North Carolina, 1981-2004. 

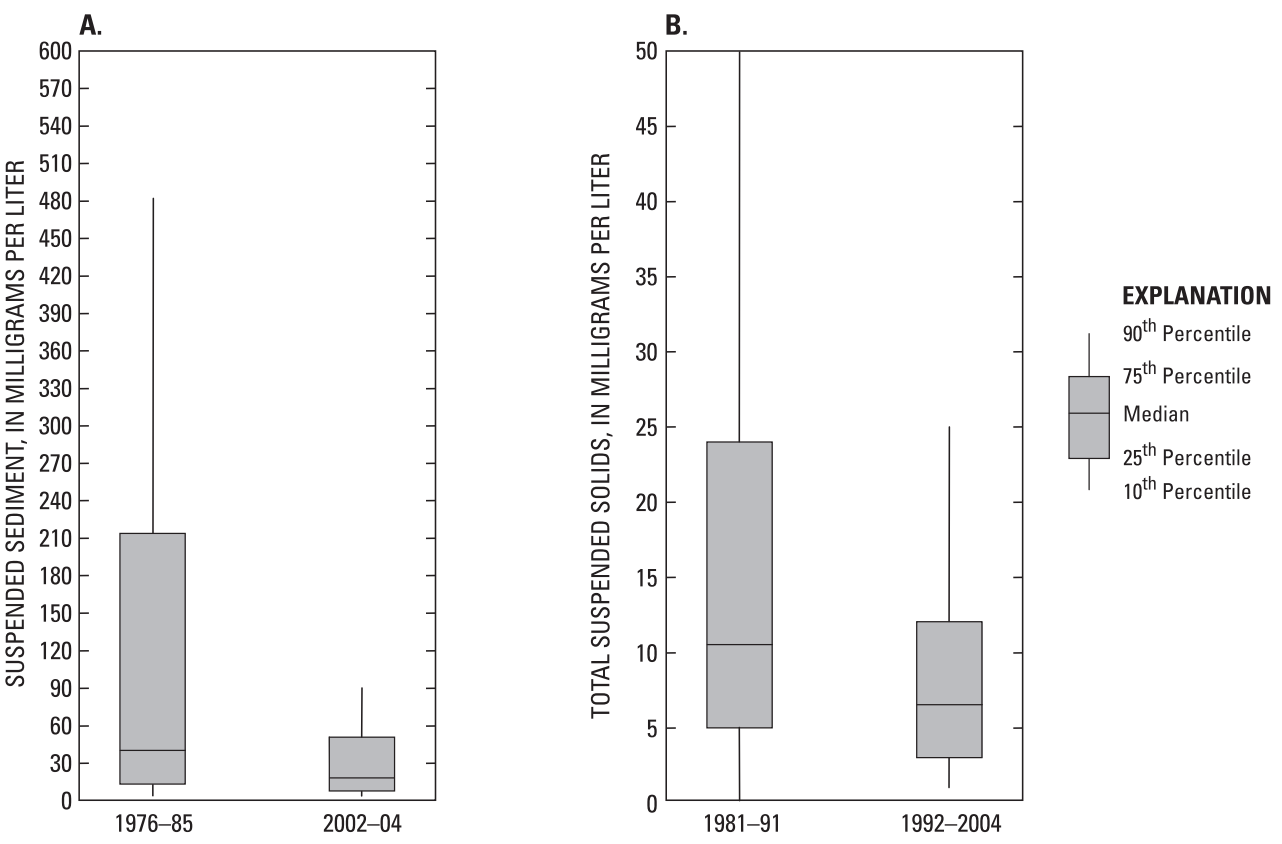

Figure 9. (A) Suspended-sediment concentrations for 1976-85 and 2002-04 from the U.S. Geological Survey, and (B) total suspended-solids concentrations for 1981-91 and 1992-2004 from the North Carolina Division of Water Quality at the Haw River near Bynum, North Carolina.

periods (1981-85 and 2002-04). Lower concentrations could be correlated to lower flows during the later period. Based on analysis of the data from the two periods, however, there was no significant difference $(\mathrm{p}>0.05)$ in instantaneous streamflow values (streamflow measurements made at the time samples were collected). Thus, the difference was not due to differences in streamflow.

Suspended-sediment concentrations for 1976-85 and 2002-04 were subdivided into four different streamflow ranges to compare concentration characteristics within each streamflow category. Higher median concentrations of suspended sediment and a greater range in streamflows occurred during the 1976-85 period compared with the 2002-04 period (fig. 10). These results confirm that suspendedsediment concentrations were higher before 1985 in comparison with the 2002-04 period, particularly with respect to streamflow greater than $5,000 \mathrm{ft}^{3} / \mathrm{s}$.

Suspended-sediment concentrations have decreased since the early 1980s, as demonstrated in the previous discussion; therefore, generally lower loads for the later calibration period (2002-04) would be expected. Suspended-sediment loads were computed twice to test this hypothesis - first using the LOADEST program to select the best of nine regression models (table 4) using the 1976-89 data early in the period (Appendix 4), and then using the LOADEST-selected best regression model using only the 2002-04 data (Appendix 4) and applying

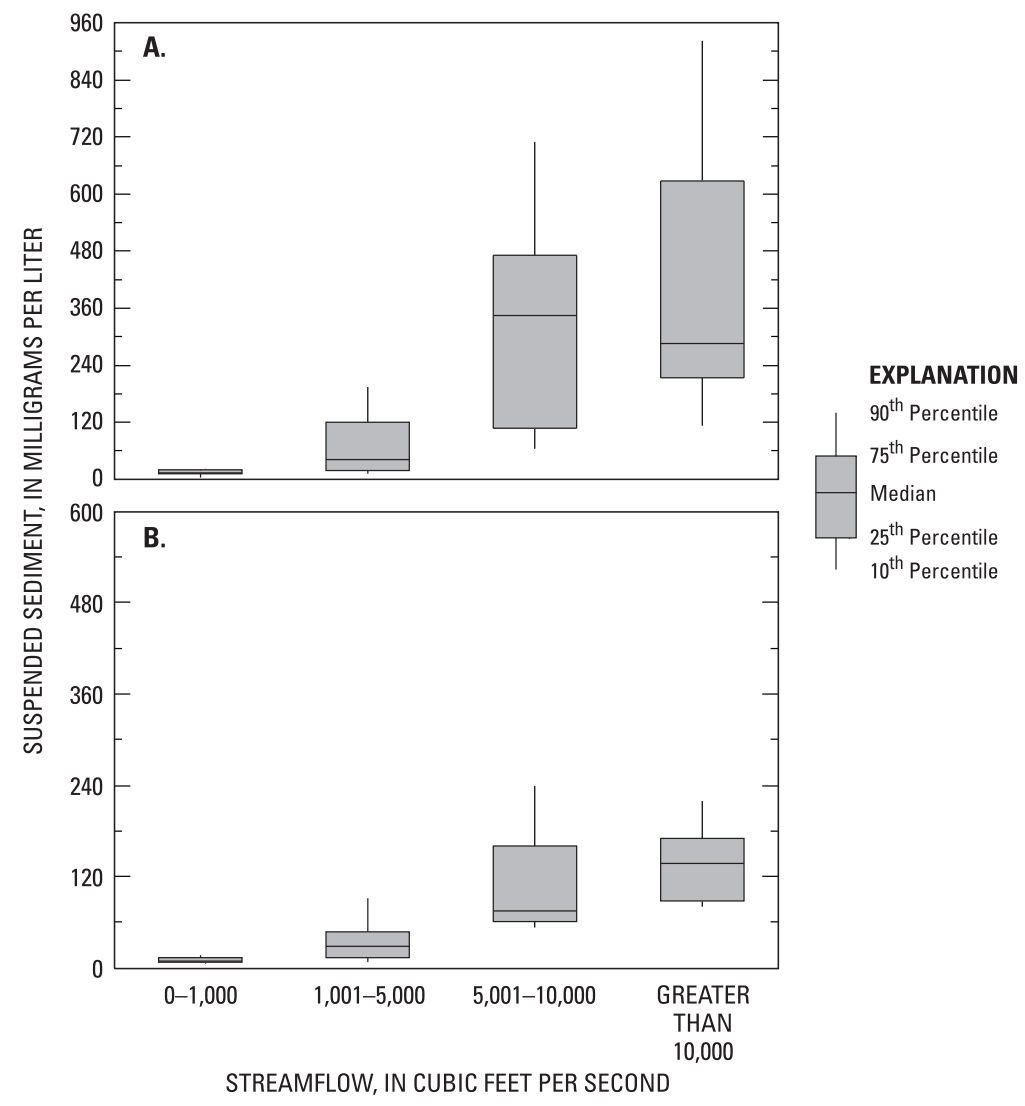

Figure 10. Suspended-sediment concentrations at four different streamflow ranges for (A) 1976-85 and (B) 2002-04 in the Haw River near Bynum, North Carolina. 
each model to the entire period of record (1976-2003) for streamflow (table 9). The loads generated for years having calibration data are actual estimated loads (because data were collected during the same period) and are shaded in table 9. The load values that are not shaded are hypothetical estimates based on streamflow and the regression model calibrated with data only from the period indicated.

Table 9. Annual suspended-sediment loads for calendar year 1976-2003 streamflows in the Haw River near Bynum, North Carolina, for two calibration periods, 1976-89 (shaded) and 2002-04 (shaded).

[Annual water-year loads from Childress and Treece (1996) are given for comparison]

\begin{tabular}{|c|c|c|c|}
\hline $\begin{array}{c}\text { Calendar } \\
\text { year }\end{array}$ & $\begin{array}{c}\text { Suspended- } \\
\text { sediment } \\
\text { load, } \\
\text { in tons, } \\
1976-89\end{array}$ & $\begin{array}{c}\text { Suspended- } \\
\text { sediment } \\
\text { load, } \\
\text { in tons, } \\
2002-04\end{array}$ & $\begin{array}{c}\text { Suspended- } \\
\text { sediment } \\
\text { load, } \\
\text { in tons, } \\
\text { from Childress } \\
\text { and Treece (1996) }\end{array}$ \\
\hline 1976 & 26,184 & 17,731 & \\
\hline 1977 & 43,051 & 23,063 & \\
\hline 1978 & 364,851 & 150,976 & \\
\hline 1979 & 438,146 & 164,179 & \\
\hline 1980 & 76,776 & 35,177 & \\
\hline 1981 & 124,482 & 41,013 & \\
\hline 1982 & 346,573 & 115,131 & \\
\hline 1983 & 166,966 & 66,483 & \\
\hline 1984 & 441,460 & 135,661 & \\
\hline 1985 & 272,081 & 78,970 & \\
\hline 1986 & 18,596 & 8,271 & \\
\hline 1987 & 561,460 & 133,412 & \\
\hline 1988 & 28,792 & 11,475 & \\
\hline 1989 & 437,338 & 112,095 & 406,000 \\
\hline 1990 & 287,132 & 73,123 & 377,000 \\
\hline 1991 & 229,357 & 57,713 & 425,000 \\
\hline 1992 & 181,897 & 45,150 & 206,000 \\
\hline 1993 & 374,586 & 86,448 & 479,000 \\
\hline 1994 & 213,940 & 48,307 & 280,000 \\
\hline 1995 & 947,247 & 139,387 & \\
\hline 1996 & $2,709,284$ & 268,932 & \\
\hline 1997 & 273,049 & 51,817 & \\
\hline 1998 & 722,783 & 119,955 & \\
\hline 1999 & 389,255 & 58,459 & \\
\hline 2000 & 147,424 & 29,103 & \\
\hline 2001 & 119,098 & 22,254 & \\
\hline $2002 \mathrm{E}$ & 403,078 & 55,977 & \\
\hline $2003 \mathrm{E}$ & $1,723,580$ & 225,375 & \\
\hline
\end{tabular}

\footnotetext{
${ }^{\mathrm{E}}$ Calendar year loads for 2002 and 2003 were estimated based on the calibration period September 2002 through August 2004.
}

Hypothetical suspended-sediment loads that would have been transported during the streamflow period 1976-2003 (median load using 2002-04 calibration data was 66,483 tons, table 9) were about 75 percent lower than loads calculated using the 1976-89 calibration data (median load for the entire streamflow period 1976-2003 was 287,132 tons, table 9). Because it has been shown that suspended sediment is significantly correlated to flow, however, it is possible that part of this difference is a result of lower streamflows during 2002 and 2003 compared with 1976-89 flows. In fact, the median flow was only slightly (about 15 percent) lower during 2002-03 $\left(1,140 \mathrm{ft}^{3} / \mathrm{s}\right.$, primarily because of the generally high flows during 2003) compared with the median flow for the period 1976-89 $\left(1,307 \mathrm{ft}^{3} / \mathrm{s}\right)$, further supporting the conclusion that suspended-sediment concentrations decreased as a result of some other factor.

The average calendar-year loads for 197689 generated from the LOADEST calibration in this analysis when compared with the average water-year loads from Childress and Treece (1996) were about 20 percent lower for the same period (1989-94). The load estimates from Childress and Treece (1996), however, fall within the 95-percent confidence interval generated by LOADEST. Loads generated for the period 1976-79 (218,000 tons) using the 1976-89 model were about 17 percent higher than the estimated average annual load (180,000 tons) for the Haw River near Bynum reported by Simmons (1993) for the period 1970-79, again well within the expected 95-percent confidence interval.

The observed decrease in suspendedsediment loads between 1976-89 and 2002-04 in the Haw River may be a result of several factors. Cropland decreased substantially between 1980 and 2000 - planted crop acreage in the basin decreased about 20 percent between 1982 and 1997 based on National Resource Inventory (NRI) data from the U.S. Department of Agriculture (USDA) (North Carolina Division of Water Quality, 2005a). Most of this decrease occurred in the 1980s. Based on crop statistics from the USDA for counties in the upper Cape Fear River basin (U.S. Department of Agriculture, 2004), total planted acreage decreased from about 330,000 acres in 1980 to about 245,000 acres in 1990, or about 24 percent (Appendix 5).

Erosion associated with farming practices is well documented (Welsch, 1991; Lal, 1995; Pimentel and others, 1995), and it is likely that the decrease in cultivated land in the basin is a major factor in the observed suspendedsediment decrease during the study period. Annual erosion from forests is about 40 pounds 
per acre compared with about 14,000 pounds per acre from cropland in the United States (Pimentel and others, 1995). Even though population and urbanization increased in the basin (North Carolina Division of Water Quality, 2000, 2005a), these factors are overshadowed by the dramatic decrease in agricultural land use in the basin that occurred during the 1980s and by improvements in crop-management practices since the 1980s. These findings are in agreement with those of Richter and others (1995), who determined that sediment transport in the Yadkin River basin in the North Carolina Piedmont decreased by about 30 percent from the 1950 s to the 1990 s, primarily because of an approximate 50 -percent decrease in cropland during the period and improvements in crop-management practices since the early 1990 s, even though residential and urban areas increased by 80 percent.

\section{Total Phosphorus in the Haw River near Bynum}

Total phosphorus data are available for the Haw River near Bynum from the USGS for three periods - monthly between 1981 and 1986, quarterly between 1992 and 1995, and monthly or biweekly from August 2002 through August 2004. Monthly phosphorus data for the Haw River also are available from the NCDWQ for January 1980 through 2004. Both total phosphorus concentrations and loads decreased in the Haw River between 1980 and 2004. Total phosphorus concentrations decreased significantly between the periods 1976-85 and 2002-04 ( $<<0.001)$ from a median of $0.34 \mathrm{mg} / \mathrm{L}$ to a median of $0.13 \mathrm{mg} / \mathrm{L}$, according to USGS data and corroborated by NCDWQ data (fig. 11). Using load data computed by LOADEST, the decrease in phosphorus loads

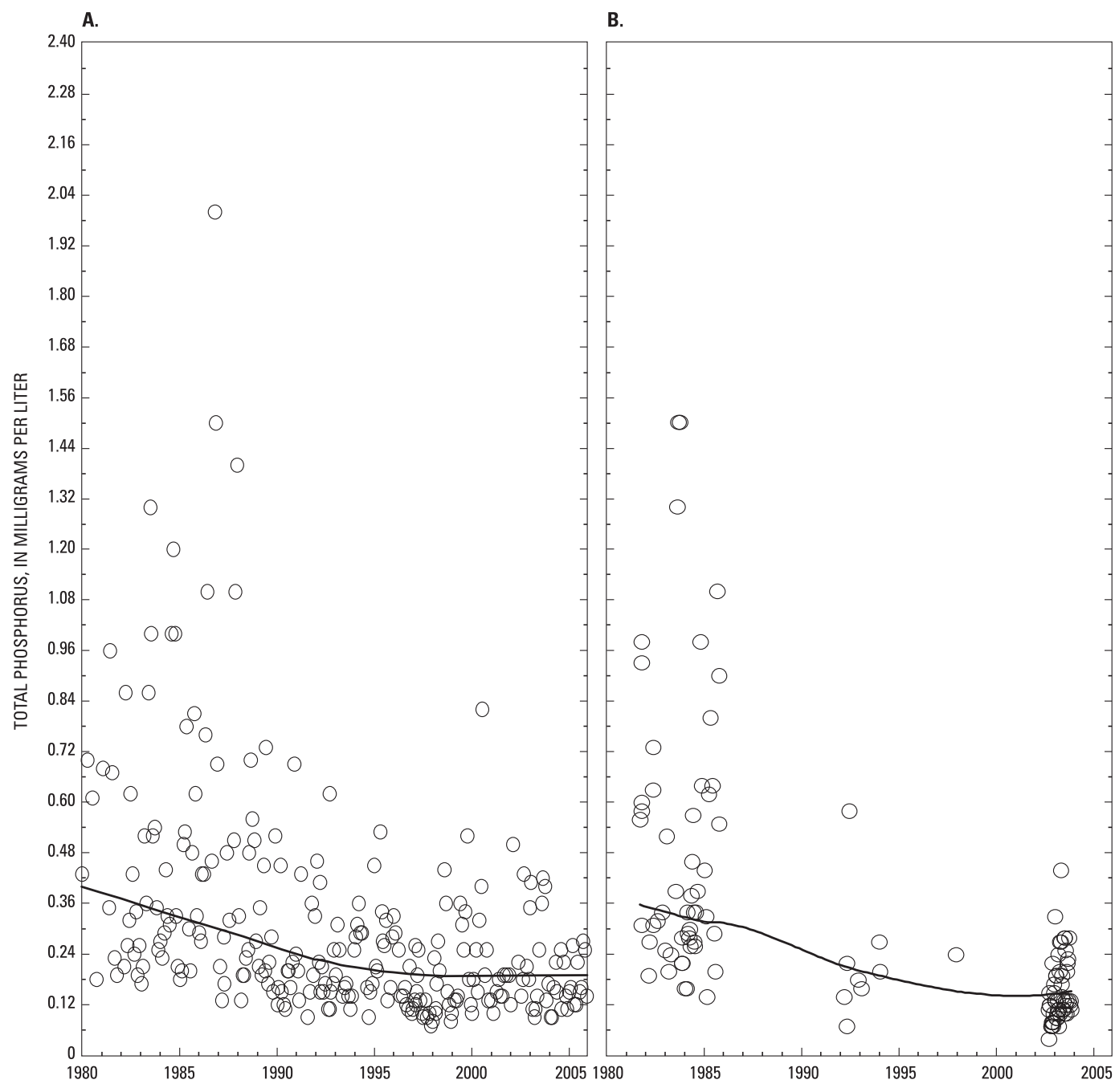

Figure 11. Total phosphorus data from (A) the North Carolina Division of Water Quality and (B) the U.S. Geological Survey for the Haw River near Bynum, North Carolina, 1980-2004, and trends indicated by LOWESS smooth lines. 
between 1981-85 and 2002-04 was similar to the decrease in sediment-more than 50 percent for annual loads (table 10). The total phosphorus loads reported by Childress and Treece (1996) are between the 1981-85 and 2002-04 model calculations. The lower phosphorus loads observed during 2002-04 compared with those in the 1980s are consistent with data from other studies, both nationally and locally.

Table 10. Annual phosphorus loads for calendar year 1976-2003 streamflows in the Haw River near Bynum, North Carolina, for two calibration periods, 1981-85 (shaded) and 2002-04 (shaded).

[Annual water-year loads from Childress and Treece (1996) are given for comparison]

\begin{tabular}{|c|c|c|c|}
\hline $\begin{array}{c}\text { Calendar } \\
\text { year }\end{array}$ & $\begin{array}{l}\text { Phosphorus } \\
\text { load, } \\
\text { in tons, } \\
\text { 1981-85 }\end{array}$ & $\begin{array}{c}\text { Phosphorus } \\
\text { load, } \\
\text { in tons, } \\
\text { 2002-04 }\end{array}$ & $\begin{array}{c}\text { Phosphorus } \\
\text { load, } \\
\text { in tons, } \\
\text { from Childress } \\
\text { and Treece (1996) }\end{array}$ \\
\hline 1976 & 324 & 106 & \\
\hline 1977 & 334 & 112 & \\
\hline 1978 & 699 & 335 & \\
\hline 1979 & 798 & 359 & \\
\hline 1980 & 373 & 145 & \\
\hline 1981 & 334 & 122 & \\
\hline 1982 & 682 & 290 & \\
\hline 1983 & 575 & 235 & \\
\hline 1984 & 740 & 332 & \\
\hline 1985 & 558 & 214 & \\
\hline 1986 & 209 & 68 & \\
\hline 1987 & 501 & 260 & \\
\hline 1988 & 264 & 85 & \\
\hline 1989 & 740 & 305 & 480 \\
\hline 1990 & 620 & 238 & 490 \\
\hline 1991 & 460 & 189 & 490 \\
\hline 1992 & 453 & 167 & 310 \\
\hline 1993 & 552 & 251 & 530 \\
\hline 1994 & 393 & 163 & 360 \\
\hline 1995 & 631 & 265 & \\
\hline 1996 & 760 & 338 & \\
\hline 1997 & 434 & 175 & \\
\hline 1998 & 553 & 280 & \\
\hline 1999 & 460 & 165 & \\
\hline 2000 & 409 & 141 & \\
\hline 2001 & 246 & 98 & \\
\hline $2002 \mathrm{E}$ & 464 & 162 & \\
\hline $2003 \mathrm{E}$ & 1,054 & 485 & \\
\hline
\end{tabular}

\footnotetext{
${ }^{\mathrm{E}}$ Calendar year loads for 2002 and 2003 were estimated based on the
} calibration period September 2002 through August 2004.
Dissolved phosphorus concentrations decreased nationwide in many streams in response to a ban on phosphorus in detergents in 1988 (Smith and others, 1993). This decrease also was noted by Childress and Treece (1996) for streams draining into Jordan Lake, including the Haw River near Bynum. Data from both the USGS and NCDWQ indicate a significant decrease in total phosphorus concentrations in the basin since 1980, primarily because of decreased point-source discharges. The median orthophosphate concentration (the dissolved portion of total phosphorus) decreased from $0.2 \mathrm{mg} / \mathrm{L}$ during $1981-85$ to about $0.06 \mathrm{mg} / \mathrm{L}$ during 2002-04, accounting for more than 50 percent of the observed decrease in total phosphorus. A comparison of 1981-85 instantaneous total phosphorus loads (median of 0.86 ton per day) with 2002-04 data (median of 0.46 ton per day) also indicated a significantly lower load ( $\mathrm{p}<0.01$ ) during the later period (fig. 12).

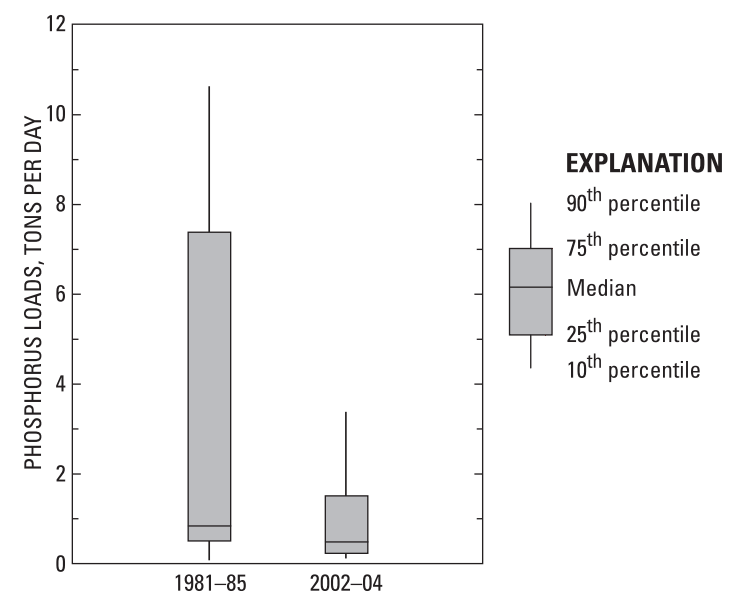

Figure 12. Instantaneous phosphorus loads for 1981-85 and 2002-04 at the Haw River near Bynum, North Carolina.

\section{Total Nitrogen in the Haw River near Bynum}

Most total nitrogen data from the USGS for the Haw River near Bynum are available for three periods - monthly between 1981 and 1985, quarterly or less frequently between 1992 and 1998, and monthly or biweekly from August 2002 through August 2004. Monthly total nitrogen data also are available from the NCDWQ for January 1980 through 2004. As with suspended sediment and total phosphorus, concentrations of total nitrogen from USGS data were significantly lower ( $\mathrm{p}<0.001$ ) using a Mann-Whitney (Conover, 1980) test for differences during the later sampling period (median of $2.2 \mathrm{mg} / \mathrm{L}$ compared with a median of $1.4 \mathrm{mg} / \mathrm{L}$ ). Concentrations of dissolved Kjeldahl nitrogen (organic nitrogen plus ammonia) decreased by half from a median concentration of 1.25 to $0.61 \mathrm{mg} / \mathrm{L}(\mathrm{p}<0.05)$ between $1981-85$ and $2002-04$, and accounted for much of the observed decrease in total 
nitrogen concentrations in the USGS data. Although the USGS total nitrogen concentrations appear to have decreased, the NCDWQ data did not indicate a corresponding decrease in total nitrogen concentrations for the period 1981-2003, during which total nitrogen concentrations remained at about $1.5 \mathrm{mg} / \mathrm{L}$ (fig. 13).

Based on the USGS data, instantaneous total nitrogen loads were not significantly different $(\mathrm{p}>0.05)$ between the two calibration periods $1981-85$ and 2002-04 (median of
6.6 tons per day compared with a median of 4.2 tons per day, $\mathrm{p}=0.08)$, although the variance was significantly lower during the later period (1,343 compared with 298). Annual total nitrogen loads, however, calculated by the LOADEST program using the 2002-04 model were about 40 percent lower than loads computed using the 1981-85 model (table 11). Because the regression models include flow and seasonal variation, the results from the LOADEST program are probably the most reliable.

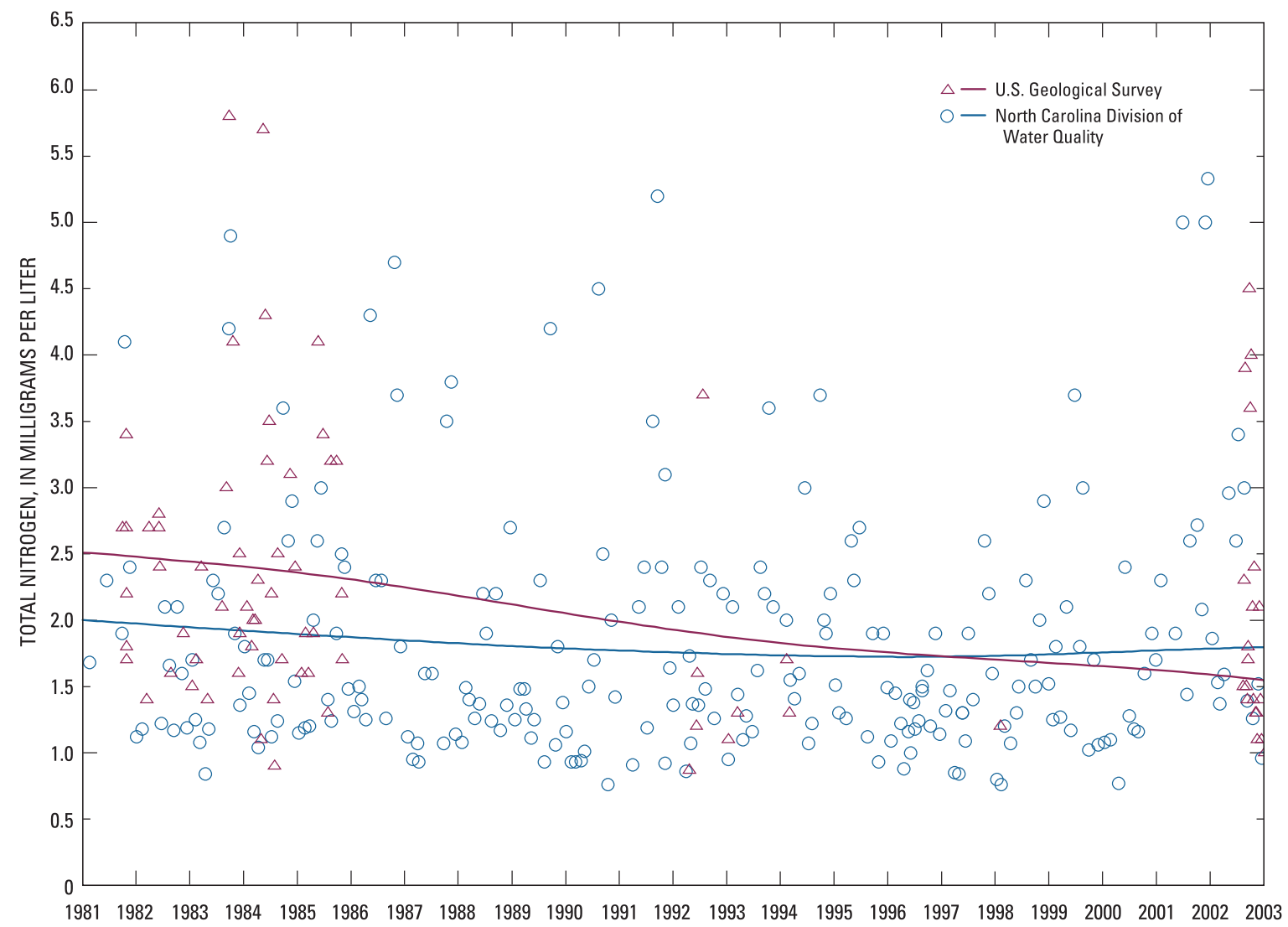

Figure 13. Total nitrogen concentrations from U.S. Geological Survey and North Carolina Division of Water Quality databases for the Haw River near Bynum, North Carolina, 1981-2003. 
Table 11. Annual total nitrogen loads for calendar year 1976-2003 streamflows in the Haw River near Bynum, North Carolina, for two calibration periods, $1981-85$ (shaded) and 2002-04 (shaded).

[Annual water-year loads from Childress and Treece (1996) are given for comparison]

\begin{tabular}{|c|c|c|c|}
\hline $\begin{array}{c}\text { Calendar } \\
\text { year }\end{array}$ & $\begin{array}{c}\text { Total } \\
\text { nitrogen } \\
\text { load, } \\
\text { in tons, } \\
\text { 1981-85 }\end{array}$ & $\begin{array}{c}\text { Total } \\
\text { nitrogen } \\
\text { load, } \\
\text { in tons, } \\
2002-04\end{array}$ & $\begin{array}{c}\text { Total } \\
\text { nitrogen } \\
\text { load, } \\
\text { in tons, } \\
\text { from Childress } \\
\text { and Treece (1996) }\end{array}$ \\
\hline 1976 & 1,790 & 1,118 & \\
\hline 1977 & 1,820 & 1,133 & \\
\hline 1978 & 4,209 & 2,476 & \\
\hline 1979 & 4,520 & 2,659 & \\
\hline 1980 & 2,295 & 1,395 & \\
\hline 1981 & 1,730 & 1,089 & \\
\hline 1982 & 3,939 & 2,308 & \\
\hline 1983 & 3,580 & 2,095 & \\
\hline 1984 & 4,403 & 2,573 & \\
\hline 1985 & 2,903 & 1,742 & \\
\hline 1986 & 1,183 & 783 & \\
\hline 1987 & 3,218 & 1,938 & \\
\hline 1988 & 1,467 & 943 & \\
\hline 1989 & 4,129 & 2,422 & 2,800 \\
\hline 1990 & 3,518 & 2,065 & 2,900 \\
\hline 1991 & 2,785 & 1,677 & 2,900 \\
\hline 1992 & 2,511 & 1,526 & 1,800 \\
\hline 1993 & 3,579 & 2,110 & 3,100 \\
\hline 1994 & 2,418 & 1,473 & 2,100 \\
\hline 1995 & 3,268 & 1,951 & \\
\hline 1996 & 3,869 & 2,306 & \\
\hline 1997 & 2,664 & 1,607 & \\
\hline 1998 & 3,690 & 2,182 & \\
\hline 1999 & 2,289 & 1,403 & \\
\hline 2000 & 2,261 & 1,380 & \\
\hline 2001 & 1,528 & 972 & \\
\hline $2002 \mathrm{E}$ & 2,248 & 1,364 & \\
\hline $2003 \mathrm{E}$ & 5,968 & 3,445 & \\
\hline
\end{tabular}

\footnotetext{
${ }^{\mathrm{E}}$ Calendar year loads for 2002 and 2003 were estimated based on the calibration period September 2002 through August 2004.
}

\section{Streamflow in the Deep River at Moncure}

Although the annual median streamflows for the Deep River at Moncure, shown in fig. 14, do not indicate a longterm trend, a significant decreasing trend in streamflow was detected for the period 1981-2003 using Spearman's rho on daily mean streamflows $(\rho=-0.03, p<0.05)$. As indicated previously for the Haw River, this change is not considered to be a significant factor in controlling water quality or explanatory for any observed trend over the past 20-30 years. Based on the information presented in figure 14, water-quality samples were collected for this investigation at streamflows that were among the lowest (2002), similar to those during the late 1980s, and the highest (2003) measured for the entire period (1980-2004).

\section{Suspended Sediment in the Deep River at Moncure}

Between 1976 and 1978, eight suspended-sediment samples were collected in the Deep River at Moncure by the USGS. Quarterly suspended-sediment samples were collected between 1981 and 1983. Because of the relatively few samples collected during 1976-83, it is difficult to reliably assess trends or changes through time. Statistical comparisons were possible, however, using the Mann-Whitney test, and enough suspended-sediment data ( 25 samples) were available to estimate loads using the LOADEST program and the calibrated model for two periods, 1976-83 and 2002-04.

Suspended-sediment concentrations were not significantly lower ( $p>0.05$ ) during 2002-04 (median of $12 \mathrm{mg} / \mathrm{L}$ ) compared with concentrations observed during 1976-83 (median of $23 \mathrm{mg} / \mathrm{L}$ ). The small sample size ( 25 samples) and large variability for the early period make it difficult to statistically discern a difference. The total suspended-solids data collected by the NCDWQ during 1992-97 and 1998-2002 also do not indicate a significant ( $\mathrm{p}>0.05)$ difference in concentrations between the two periods.

The suspended-sediment loads for calendar years 1976-2003 were computed using a model calibrated with the historical dataset (1976-83) and compared with loads from a model calibrated with the current dataset (2002-04). Using this procedure, much larger loads (about a factor of 2 or greater) were calculated for the 1976-83 period than for the 2002-04 period (table 12). These results are not in agreement with results from the two-sample statistical tests; however, because the LOADEST model accounts for streamflow and concentration and considering that cropland decreased between 1980 and 1990 (Appendix 5), it appears likely that suspended-sediment loads have decreased somewhat in the Deep River since the late 1970s and early 1980s. 


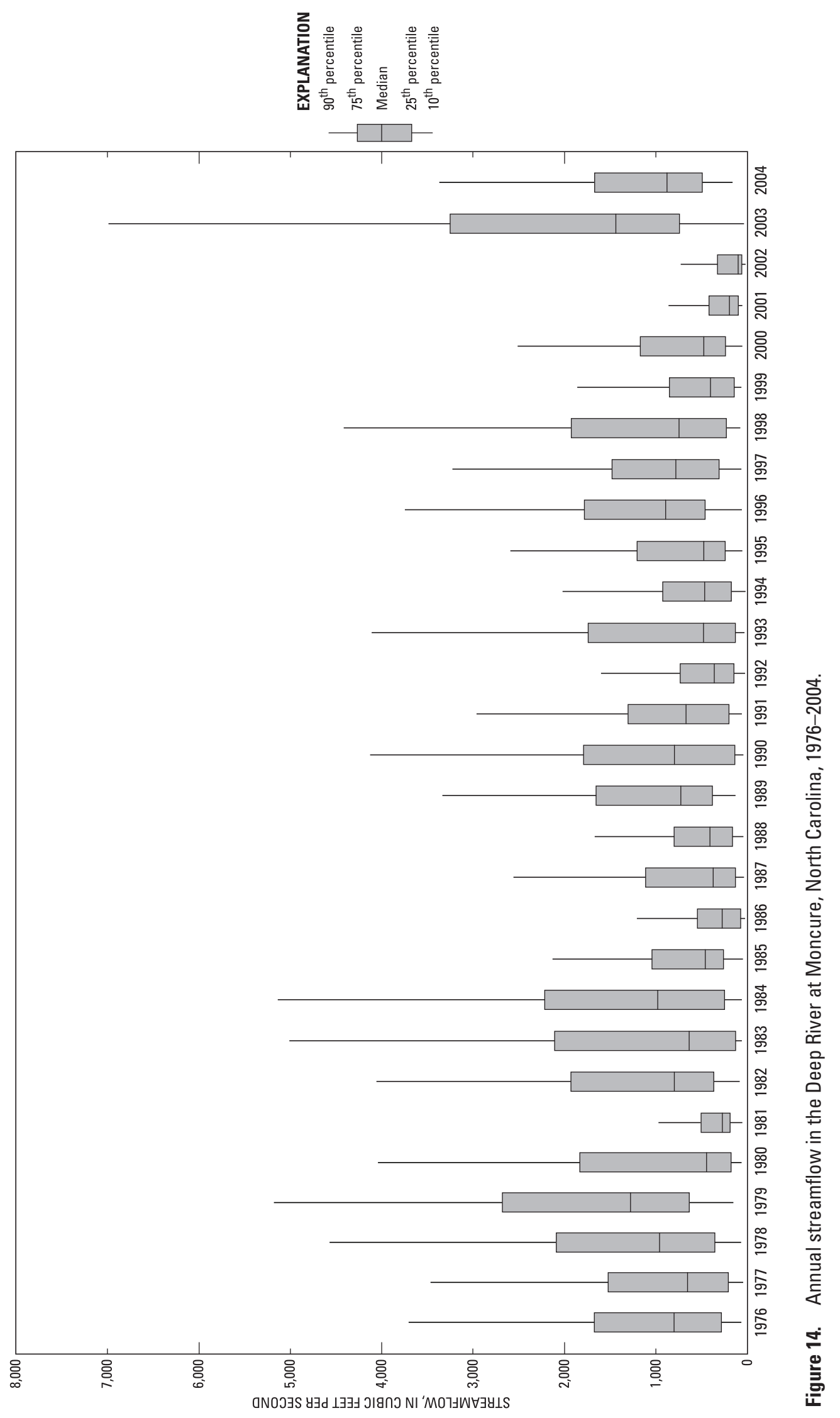


Table 12. Annual suspended-sediment loads for calendar year 1976-2003 streamflows in the Deep River at Moncure, North Carolina, for two calibration periods, 1976-83 (shaded) and 2002-04 (shaded).

\begin{tabular}{|c|c|c|}
\hline $\begin{array}{c}\text { Calendar } \\
\text { year }\end{array}$ & $\begin{array}{l}\text { Suspended- } \\
\text { sediment } \\
\text { load, } \\
\text { in tons, } \\
\text { 1976-84 }\end{array}$ & $\begin{array}{c}\text { Suspended- } \\
\text { sediment } \\
\text { load, } \\
\text { in tons, } \\
2002-04\end{array}$ \\
\hline 1976 & 120,900 & 50,229 \\
\hline 1977 & 174,031 & 69,169 \\
\hline 1978 & 354,560 & 134,469 \\
\hline 1979 & 510,623 & 188,153 \\
\hline 1980 & 148,588 & 60,383 \\
\hline 1981 & 77,231 & 32,188 \\
\hline 1982 & 323,263 & 126,352 \\
\hline 1983 & 334,818 & 130,050 \\
\hline 1984 & 539,219 & 201,398 \\
\hline 1985 & 315,449 & 118,995 \\
\hline 1986 & 42,755 & 18,363 \\
\hline 1987 & 243,932 & 91,609 \\
\hline 1988 & 72,277 & 30,602 \\
\hline 1989 & 466,355 & 176,545 \\
\hline 1990 & 247,544 & 98,553 \\
\hline 1991 & 181,069 & 71,377 \\
\hline 1992 & 133,334 & 54,201 \\
\hline 1993 & 348,962 & 131,104 \\
\hline 1994 & 128,071 & 51,269 \\
\hline 1995 & 381,169 & 144,421 \\
\hline 1996 & 294,742 & 112,914 \\
\hline 1997 & 255,027 & 98,784 \\
\hline 1998 & 632,064 & 227,694 \\
\hline 1999 & 187,904 & 73,529 \\
\hline 2000 & 101,454 & 42,496 \\
\hline 2001 & 55,928 & 22,847 \\
\hline $2002 \mathrm{E}$ & 156,266 & 62,016 \\
\hline $2003 \mathrm{E}$ & 538,047 & 202,519 \\
\hline
\end{tabular}

\footnotetext{
${ }^{\mathrm{E}}$ Calendar year loads for 2002 and 2003 were estimated based on the calibration period September 2002 through August 2004.
}

\section{Total Phosphorus in the Deep River at Moncure}

Sampling for nutrients in the Deep River was conducted by the USGS during 1981-83. Total suspended-solids and nutrient data are available from the NCDWQ for the period 1992-2004. Based on the USGS data, total phosphorus concentrations in the Deep River were not significantly ( $p>0.05$ ) different for the period 1981-83 (median of $0.22 \mathrm{mg} / \mathrm{L}$ ) than for $2002-04$ (median of $0.21 \mathrm{mg} / \mathrm{L}$ ), and total phosphorus concentrations have remained near those measured in the early 1980s. No influence related to improvements in wastewater treatment or the ban on phosphorus in detergents was evident in the available phosphorus data. As indicated previously, the occurrence of continuous discharges (from point sources or ground water) of phosphorus upstream from this site are the likely source of elevated phosphorus concentrations in the Deep River. Nutrient loads for the period 1981-83 could not be estimated from the USGS data because too few samples $(<24)$ were available for calibration using the LOADEST program.

\section{Total Nitrogen in the Deep River at Moncure}

As with total phosphorus, total nitrogen concentrations were not significantly different $(p>0.05)$ in the Deep River for the period 1981-83 (median of 1.75) than for 2002-04 (median of 1.5). Data from the NCDWQ also did not significantly ( $\mathrm{p}>0.05$ ) differ for the two periods 1992-97 (median of 1.17) and 1997-2002 (median of 1.11), although these data-collection periods do not reflect any changes since the late 1970s or early 1980s, which are the focus of this report. Although both the USGS and NCDWQ datasets do not indicate a significant change through time for either comparison period, total nitrogen concentrations were significantly $(\mathrm{p}<0.05)$ higher in the USGS data than in the NCDWQ data, indicating that the data are not directly comparable and may yield significantly different values for load calculations.

\section{Summary and Conclusions}

Water-quality samples were collected from the Haw River near Bynum and the Deep River at Moncure, NC, over a 2-year period beginning in August 2002 and ending in August 2004. Regular sampling was conducted at approximately 1- to 2-week intervals for nutrients and suspended sediment. Sampling for nutrients, suspended sediment, major ions, and trace elements was conducted during targeted runoff events. Samples were collected over a wide range of hydrologic conditions during the 2-year sampling period, beginning with an extremely dry water year (2002), continuing through an extremely wet water year (2003), and ending during a more hydrologically normal water year (2004). This range of streamflows provides a useful dataset for comparing waterquality characteristics and nutrient and sediment loads in 
these two major river basins in the Piedmont Physiographic Province.

Based on analysis of the major ion composition, water in both the Haw and Deep Rivers is of mixed ionic composition that tends to be dominated by calcium and bicarbonate during high flows in the winter and spring and by sodium and chloride during low flows in the summer and fall. In general, the ionic composition of water in the Haw River near Bynum was more variable than in the Deep River at Moncure. Average concentrations of suspended sediment and total nitrogen in water from both rivers were similar. During the investigation, however, total phosphorus concentrations were significantly higher in the Deep River (median of $0.21 \mathrm{mg} / \mathrm{L}$ ) than total phosphorus concentrations in the Haw River (median of $0.13 \mathrm{mg} / \mathrm{L}$ ), which is indicative that more phosphorus enters the Deep River basin through continuous (point-source or ground-water) discharges.

Annual loads were computed for calendar years 2002 and 2003 using data collected during this investigation. During calendar year 2002, the Haw River near Bynum transported 1,400 tons of total nitrogen, 160 tons of total phosphorus, and 56,000 tons of suspended sediment. In 2003, the Haw River transported 3,400 tons of total nitrogen, 470 tons of total phosphorus, and 230,000 tons of suspended sediment. The yields for total nitrogen were 1.1 (tons/yr)/mi² in 2002 and 2.7 (tons $/ \mathrm{yr}$ ) $/ \mathrm{mi}^{2}$ in 2003 . The yields for total phosphorus were 0.13 (ton/yr) $/ \mathrm{mi}^{2}$ in 2002 and 0.37 (ton $/ \mathrm{yr}$ ) $/ \mathrm{mi}^{2}$ in 2003 . Suspended-sediment yields were 44 (tons/yr)/mi in 2002 and 180 (tons/yr)/mi in 2003. The reported annual loads for the Haw River were estimated to be generally within 30-50 percent of the actual loads transported.

Loads and yields were consistently higher in the Deep River than in the Haw River for total nitrogen, total phosphorus, and suspended sediment. The Deep River at Moncure transported 1,700 tons of total nitrogen, 260 tons of total phosphorus, and 88,000 tons of suspended sediment during calendar year 2002. During calendar year 2003 the river transported 4,000 tons of total nitrogen, 740 tons of total phosphorus, and 380,000 tons of suspended sediment. The yields for total nitrogen were 1.2 (tons/yr)/mi² in 2002 and 2.8 (tons $/ \mathrm{yr}$ ) $/ \mathrm{mi}^{2}$ in 2003 . The yields for total phosphorus were 0.18 (ton/yr) $/ \mathrm{mi}^{2}$ in 2002 and 0.52 (ton $/ \mathrm{yr}$ ) $/ \mathrm{mi}^{2}$ in 2003 . Suspended-sediment yields were 61 (tons/yr)/mi 2002 and 270 (tons/yr) $/ \mathrm{mi}^{2}$ in 2003.

Loads were also calculated to provide insight on the seasonal transport of loads of nutrients and sediment in the Haw and Deep Rivers. During this investigation, loads of all constituents analyzed were greatest during the spring and summer months of 2003, an extremely wet year, and lowest during the fall and winter months. During 2004, a more normal year hydrologically, primary transport occurred during the winter months. Because water year 2003 was much wetter than water year 2004, significantly greater loads during the first four seasons were transported than the last four at both sites. The largest loads of all constituents sampled during the spring of 2003 were transported at both sites.
Compared with the Haw River, the Deep River generally had higher yields of sediment and nutrients, particularly phosphorus, even though the Deep River basin generally has more forested land, less cropland, and less developed land. Possible reasons for higher yields in the Deep River than in the Haw River include (1) more stringent regulations for dischargers along the Haw River, because it is designated as Nutrient Sensitive Water by the NCDWQ; (2) substantially more livestock present in the Deep River basin, particularly poultry; and (3) more dams located on the Haw River (59) than on the Deep River (34).

Historical streamflow and water-quality data at both sites, collected by the USGS and the NCDWQ, were used to evaluate historical changes through time and to compare information provided by the two datasets. Water-quality changes were greatest in the Haw River near Bynum, with a definable decrease in suspended-sediment, total nitrogen, and total phosphorus concentrations and loads. Loss of cropland between 1980 and 1990 and improved land-management practices account for the decrease in suspended-sediment loads, and improved wastewater-treatment practices in the Haw River basin account for the lower nutrient concentrations. Because of the small number of nutrient and suspendedsediment samples collected in the Deep River, changes over time were not detected using a Mann-Whitney two-sample test for suspended sediment, total nitrogen, or total phosphorus. A regression model calibrated for the 1981-83 streamflow and concentration data, however, yielded hypothetical loads twice those calculated using 2002-04 data, indicating that suspended-sediment loads have decreased since the early 1980s in the Deep River. Nutrient concentrations in the Deep River, however, have remained relatively unchanged since the early 1980s.

\section{References}

Bara, T.J., comp., ed., 1994, Multi-resolution land characteristics consortium documentation notebook [Environmental Monitoring and Assessment Program (EMAP)_Landscape Characterization, Contract 68-DO-0106]: Research Triangle Park, NC, ManTech Environmental Technology, Inc. [variously paged].

Childress, C.J.O., and Treece, M.W., Jr., 1996, Water and bedmaterial quality of selected streams and reservoirs in the Research Triangle area of North Carolina, 1988-94: U.S. Geological Survey Water-Resources Investigations Report 95-4282, 79 p.

Cohn, T.A., 1988, Adjusted maximum likelihood estimation of the moments of lognormal populations from type I censored samples: U.S. Geological Survey Open-File Report 88-350, $34 \mathrm{p}$. 
Conover, W.J., 1980, Practical non-parametric statistics: New York, John Wiley and Sons, 493 p.

Earth Satellite Corporation (EarthSat), 1997, Comprehensive land cover mapping for the State of North Carolina-Final report prepared for North Carolina Center for Geographic Information and Analysis, March 1997, Appendix A, Land cover classification system; accessed July 28, 2005, at http://cgia.cgia.state.nc.us/cgdb/refdocs/lc96/apdx-a.html

Fishman, M.J., 1993, Methods of analysis by the U.S. Geological Survey National Water Quality LaboratoryDetermination of inorganic and organic constituents in water and fluvial sediments: U.S. Geological Survey OpenFile Report 93-125, 217 p.

Fishman, M.J., and Friedman, L.C., eds., 1989, Methods for determination of inorganic substances in water and fluvial sediments: U.S. Geological Survey Techniques of WaterResources Investigations, book 5, chap. A1, 545 p.

Gray, J.R., Glysson, G.D., Turcios, L.M., and Schwarz, G.E., 2000, Comparability of suspended-sediment concentration and total suspended solids data: U.S. Geological Survey Water-Resources Investigations Report 00-4191, 14 p.

Lal, R., 1995, Global soil erosion by water and carbon dynamics, in Lal, R., Kimble, J., Levine, E., and Stewart, B.A., eds., Soils and global change: Boca Raton, FL, CRC Lewis Publishers, p. 131-142.

Mallin, M.A., 2000, Impacts of industrial animal production on rivers and estuaries: American Scientist v. 88, no. 1, p. $26-37$.

North Carolina Department of Environment and Natural Resources, 2004, Basinwide assessment report, Cape Fear River basin: Raleigh, North Carolina Department of Environment and Natural Resources, Division of Water Quality, Environmental Sciences Section, 337 p.; accessed in January 2005 at http://www.esb.enr.state.nc.us/Basinwide/ CPF\%202004\%20Report\%20Final.pdf

North Carolina Division of Water Quality, 2000, Basinwide planning program-2000 Cape Fear River basinwide water quality plan; accessed in December 2004 at http://h2o.enr. state.nc.us/basinwide/Capefear/capefearindex.htm

North Carolina Division of Water Quality, 2003, Water quality standards for freshwater classifications, April 1, 2003; accessed May 25, 2005, at http://h2o.enr.state.nc.us/csu/ fwtabapr03.pdf

North Carolina Division of Water Quality, 2005a, Basinwide planning program-DRAFT March 2005 Cape Fear River basinwide water quality plan; accessed on July 28, 2005, at http://h2o.enr.state.nc.us/basinwide/draftCPFApril2005.htm
North Carolina Division of Water Quality, 2005b, NC Division of Water Quality ambient monitoring network-Data for Cape Fear River basin; accessed July 26, 2005, at http:// h2o.enr.state.nc.us/esb/stations/ams.htm

Pimentel, D., Harvey, C., Resosudarmo, P., Sinclair, K., Kurz, D., McNair, M., Crist, S., Shpritz, L., Fitton, L., Saffouri, R., and Blair, R., 1995, Environmental and economic costs of soil erosion and conservation benefits: Science, v. 267, no. 5201, p. 1117-1123.

Ragland, B.C., Barker, R.G., and Robinson, J.B., 2003, Water resources data, North Carolina, water year 2002: U.S. Geological Survey Water-Data Report NC-02-1B, 665 p.

Ragland, B.C., Barker, R.G., and Robinson, J.B., 2004, Water resources data, North Carolina, water year 2003: U.S. Geological Survey Water-Data Report NC-03-1B, 796 p.

Rantz, S.E., and others, 1982, Measurement and computation of streamflow: v. 1. Measurement of stage and discharge; v. 2. Computation of discharge: U.S. Geological Survey Water-Supply Paper 2175, 631 p.

Richter, D.D., Korfmacher, K., and Nau, R., 1995, Decreases in Yadkin River basin sedimentation-Statistical and geographic time-trend analyses, 1951 to 1990: Raleigh, NC, Water Resources Research Institute of The University of North Carolina, Report No. 297, 93 p.

Runkel, R.L., Crawford, C.G., and Cohn, T.A., 2004, Load estimator (LOADEST) —A FORTRAN program for estimating constituent loads in streams and rivers: U.S. Geological Survey Techniques and Methods, book 4, chap. A5, 75 p.

Simmons, C.E., 1993, Sediment characteristics of North Carolina streams, 1970-79: U.S. Geological Survey WaterSupply Paper 2364, 84 p.

Simmons, C.E., and Heath, R.C., 1982, Water-quality characteristics of streams in forested and rural areas of North Carolina: U.S. Geological Survey Water-Supply Paper 2185, chap. B, 33 p.

Smith, R.A., Alexander, R.B., and Lanfear, K.J., 1993, Stream water quality in the conterminous United States-Status and trends of selected indicators during the 1980's, in U.S. Geological Survey, 1993, National water summary 1990-91Hydrologic events and stream water quality: U.S. Geological Survey Water-Supply Paper 2400, p. 111-140.

Upper Cape Fear River Basin Association, 2005, Description of the association and the upper Cape Fear River basin; accessed on May 26, 2005, at http://www.cfra-nc.org/ ucfrba.htm 
U.S. Department of Agriculture, 2004, National Agricultural Statistics Service, Quick stats-Agricultural statistics database; accessed in May 2005 at http://www.nass.usda. gov/QuickStats/

U.S. Geological Survey, variously dated, National field manual for the collection of water-quality data: U.S. Geological Survey Techniques of Water-Resources Investigations, book 9, chaps. A1-A9, available online at http://pubs.water. usgs.gov/twri9A
Walters, D.A., Robinson, J.B., and Barker, R.G., 2005, Waterresources data, North Carolina, water year 2004: U.S. Geological Survey Water-Data Report NC-04-1, 1,295 p.

Welsch, D.J., 1991, Riparian forest buffers-Function and design for protection and enhancement of water resources: Radnor, PA, U.S. Department of Agriculture, Forest Service Technical Publication NA-PR-07-91. 



\section{Appendixes}

Appendix 1. Nutrient and suspended-sediment concentrations in water samples from the Haw River near Bynum, North Carolina

Appendix 2. Nutrient and suspended-sediment concentrations in water samples from the Deep River at Moncure, North Carolina

Appendix 3. Selected major ions and trace element concentrations in water samples from (A) the Haw River near Bynum and (B) the Deep River at Moncure, North Carolina

Appendix 4. Equations used in load calculations for suspended sediment, total nitrogen, and phosphorus in (A) the Haw River near Bynum and (B) the Deep River at Moncure, North Carolina

Appendix 5. Planted crop acreage in counties in the upper Cape Fear River basin, 1980-2004 

Appendix 1. Nutrient and suspended-sediment concentrations in water samples from the Haw River near Bynum, North Carolina.

[mg/L, milligrams per liter; N, nitrogen; P, phosphorus; — , no data; <, less than; E, estimated]

\begin{tabular}{|c|c|c|c|c|c|c|c|c|c|}
\hline Date & Time & $\begin{array}{c}\text { Ammonia } \\
\text { plus organic } \\
\text { nitrogen, water, } \\
\text { unfiltered, in } \\
\text { mg/L as } N\end{array}$ & $\begin{array}{c}\text { Ammonia, } \\
\text { water, } \\
\text { filtered, in } \\
\text { mg/L as } N\end{array}$ & $\begin{array}{c}\text { Nitrite } \\
\text { plus } \\
\text { nitrate, } \\
\text { water, } \\
\text { filtered, in } \\
\text { mg/L as } \mathrm{N}\end{array}$ & $\begin{array}{c}\text { Nitrite, } \\
\text { water, } \\
\text { filtered, in } \\
\mathrm{mg} / \mathrm{L} \text { as } \mathrm{N}\end{array}$ & $\begin{array}{c}\text { Total } \\
\text { nitrogen, } \\
\text { water, } \\
\text { unfiltered, } \\
\text { in } \mathrm{mg} / \mathrm{L} \\
\text { as } \mathrm{N}\end{array}$ & $\begin{array}{c}\text { Ortho- } \\
\text { phosphate, } \\
\text { water, } \\
\text { filtered, in } \\
\text { mg/L as } P\end{array}$ & $\begin{array}{l}\text { Phosphorus, } \\
\text { water, } \\
\text { unfiltered, } \\
\text { in } \mathrm{mg} / \mathrm{L}\end{array}$ & $\begin{array}{c}\text { Suspended } \\
\text { sediment, } \\
\text { in } \mathrm{mg} / \mathrm{L}\end{array}$ \\
\hline $8 / 14 / 2002$ & 0930 & 0.97 & 0.038 & 0.53 & 0.007 & 1.5 & 0.252 & - & 6 \\
\hline $8 / 20 / 2002$ & 0945 & 1.20 & 0.056 & 1.18 & 0.015 & 2.3 & 0.276 & - & 7 \\
\hline $8 / 27 / 2002$ & 1300 & 1.70 & 0.239 & 2.17 & 0.044 & 3.9 & 0.462 & - & 9 \\
\hline 9/4/2002 & 1200 & 0.72 & 0.086 & 0.73 & 0.010 & 1.5 & 0.058 & - & 17 \\
\hline $9 / 11 / 2002$ & 1145 & 0.60 & 0.016 & 0.81 & 0.004 & 1.4 & 0.083 & - & 9 \\
\hline $9 / 17 / 2002$ & 1030 & 0.72 & 0.026 & 1.00 & 0.005 & 1.7 & 0.089 & - & 9 \\
\hline $9 / 17 / 2002$ & 1100 & 0.74 & 0.025 & 1.01 & 0.005 & 1.8 & 0.091 & - & 7 \\
\hline $9 / 25 / 2002$ & 1100 & 1.00 & 0.036 & 3.46 & 0.016 & 4.5 & 0.327 & - & 18 \\
\hline $10 / 1 / 2002$ & 1145 & 0.92 & 0.025 & 2.72 & 0.012 & 3.6 & 0.255 & - & 4 \\
\hline $10 / 7 / 2002$ & 1100 & 0.83 & 0.026 & 3.14 & 0.016 & 4.0 & 0.278 & - & 5 \\
\hline $10 / 15 / 2002$ & 1430 & 0.81 & 0.095 & 1.34 & 0.013 & 2.1 & 0.067 & - & 41 \\
\hline $10 / 22 / 2002$ & 1330 & 0.60 & 0.052 & 0.84 & 0.011 & 1.4 & 0.056 & - & 10 \\
\hline $10 / 29 / 2002$ & 0915 & 0.89 & 0.046 & 1.55 & 0.013 & 2.4 & 0.177 & - & 46 \\
\hline 11/5/2002 & 1100 & 0.53 & 0.020 & 0.75 & 0.010 & 1.3 & 0.069 & - & 6 \\
\hline $11 / 12 / 2002$ & 0900 & 0.72 & 0.025 & 0.63 & 0.009 & 1.3 & 0.080 & - & 55 \\
\hline $11 / 19 / 2002$ & 1145 & 0.67 & 0.063 & 0.41 & 0.009 & 1.1 & 0.034 & 0.11 & 30 \\
\hline $11 / 26 / 2002$ & 1000 & $<0.1$ & 0.023 & 0.96 & 0.011 & - & 0.044 & $<0.04$ & 5 \\
\hline $12 / 3 / 2002$ & 0845 & 0.58 & $<0.015$ & 1.49 & 0.007 & 2.1 & 0.109 & 0.15 & 5 \\
\hline $12 / 9 / 2002$ & 0930 & 0.71 & 0.077 & 0.73 & 0.008 & 1.4 & 0.058 & 0.12 & 12 \\
\hline $12 / 17 / 2002$ & 0915 & 0.60 & 0.064 & 0.51 & 0.008 & 1.1 & 0.021 & 0.12 & 51 \\
\hline $1 / 8 / 2003$ & 0930 & 0.40 & 0.018 & 0.60 & 0.008 & 1.0 & 0.022 & 0.07 & 11 \\
\hline $1 / 14 / 2003$ & 0915 & 0.48 & 0.041 & 1.10 & 0.022 & 1.6 & 0.035 & 0.07 & 7 \\
\hline $1 / 21 / 2003$ & 0900 & 0.50 & 0.018 & 1.31 & 0.020 & 1.8 & 0.032 & 0.08 & 5 \\
\hline $1 / 30 / 2003$ & 0945 & 0.65 & 0.099 & 1.45 & 0.042 & 2.1 & 0.043 & 0.08 & 6 \\
\hline $2 / 5 / 2003$ & 0915 & 0.45 & 0.018 & 0.63 & 0.011 & 1.1 & 0.015 & 0.07 & 8 \\
\hline 2/7/2003 & 1145 & 0.85 & 0.249 & 0.59 & 0.030 & 1.4 & 0.127 & 0.22 & 38 \\
\hline $2 / 11 / 2003$ & 0930 & 0.50 & 0.062 & 0.53 & 0.012 & 1.0 & 0.023 & 0.08 & 12 \\
\hline $2 / 21 / 2003$ & 1200 & 1.00 & 0.395 & 0.92 & 0.031 & 1.9 & 0.039 & 0.10 & 18 \\
\hline $2 / 25 / 2003$ & 0900 & 0.68 & 0.039 & 0.40 & 0.008 & 1.1 & 0.012 & 0.17 & 58 \\
\hline $3 / 7 / 2003$ & 0915 & 0.69 & 0.108 & 0.41 & 0.014 & 1.1 & 0.049 & 0.15 & 51 \\
\hline $3 / 21 / 2003$ & 0845 & 1.00 & 0.105 & 0.22 & 0.007 & 1.3 & 0.024 & 0.33 & 218 \\
\hline $3 / 24 / 2003$ & 1200 & 0.56 & 0.039 & 0.39 & 0.009 & 1.0 & 0.015 & 0.13 & 32 \\
\hline 4/1/2003 & 0915 & 0.64 & 0.066 & 0.48 & 0.016 & 1.1 & 0.031 & 0.13 & 31 \\
\hline 4/8/2003 & 0930 & 0.80 & 0.045 & 0.30 & 0.008 & 1.1 & 0.039 & 0.19 & 137 \\
\hline 4/10/2003 & 1030 & 0.62 & 0.056 & 0.25 & 0.006 & 0.9 & 0.068 & 0.19 & 86 \\
\hline $4 / 15 / 2003$ & 0845 & 0.73 & 0.026 & 0.40 & 0.007 & 1.1 & 0.037 & 0.09 & 28 \\
\hline $4 / 22 / 2003$ & 0915 & 0.46 & 0.015 & 0.71 & 0.009 & 1.2 & 0.035 & 0.09 & 19 \\
\hline $5 / 2 / 2003$ & 1130 & 0.55 & $<0.015$ & 0.57 & 0.005 & 1.1 & 0.049 & 0.10 & 9 \\
\hline $5 / 9 / 2003$ & 1030 & 0.50 & E 0.014 & 0.98 & 0.007 & 1.5 & 0.088 & 0.13 & 5 \\
\hline $5 / 14 / 2003$ & 0845 & 0.47 & E 0.011 & 0.69 & 0.006 & 1.2 & 0.073 & 0.11 & 6 \\
\hline $5 / 23 / 2003$ & 1000 & 0.92 & 0.048 & 0.53 & 0.012 & 1.5 & 0.045 & 0.24 & 80 \\
\hline $5 / 28 / 2003$ & 0930 & 0.55 & 0.037 & 0.31 & 0.009 & 0.9 & 0.026 & 0.07 & 66 \\
\hline $6 / 2 / 2003$ & 1100 & 0.55 & E 0.013 & 0.48 & 0.007 & 1.0 & 0.033 & 0.11 & 18 \\
\hline
\end{tabular}


Appendix 1. Nutrient and suspended-sediment concentrations in water samples from the Haw River near Bynum, North Carolina.-Continued

[mg/L, milligrams per liter; N, nitrogen; P, phosphorus; —, no data; <, less than; E, estimated]

\begin{tabular}{|c|c|c|c|c|c|c|c|c|c|}
\hline Date & Time & $\begin{array}{c}\text { Ammonia } \\
\text { plus organic } \\
\text { nitrogen, water, } \\
\text { unfiltered, in } \\
\mathrm{mg} / \mathrm{L} \text { as } \mathrm{N}\end{array}$ & $\begin{array}{c}\text { Ammonia, } \\
\text { water, } \\
\text { filtered, in } \\
\mathrm{mg} / \mathrm{L} \text { as } \mathrm{N}\end{array}$ & $\begin{array}{c}\text { Nitrite } \\
\text { plus } \\
\text { nitrate, } \\
\text { water, } \\
\text { filtered, in } \\
\text { mg/L as N }\end{array}$ & $\begin{array}{c}\text { Nitrite, } \\
\text { water, } \\
\text { filtered, in } \\
\mathrm{mg} / \mathrm{L} \text { as } \mathrm{N}\end{array}$ & $\begin{array}{c}\text { Total } \\
\text { nitrogen, } \\
\text { water, } \\
\text { unfiltered, } \\
\text { in } \mathrm{mg} / \mathrm{L} \\
\text { as } \mathrm{N}\end{array}$ & $\begin{array}{c}\text { Ortho- } \\
\text { phosphate, } \\
\text { water, } \\
\text { filtered, in } \\
\mathrm{mg} / \mathrm{L} \text { as } P\end{array}$ & $\begin{array}{l}\text { Phosphorus, } \\
\text { water, } \\
\text { unfiltered, } \\
\text { in } \mathrm{mg} / \mathrm{L}\end{array}$ & $\begin{array}{c}\text { Suspended } \\
\text { sediment, } \\
\text { in } \mathrm{mg} / \mathrm{L}\end{array}$ \\
\hline $6 / 13 / 2003$ & 0930 & 0.69 & 0.024 & 0.52 & 0.007 & 1.2 & 0.075 & 0.20 & 52 \\
\hline $6 / 20 / 2003$ & 0930 & 0.92 & 0.036 & 0.54 & 0.010 & 1.5 & 0.072 & 0.27 & 90 \\
\hline $6 / 24 / 2003$ & 0900 & 0.61 & Е 0.009 & 0.60 & 0.003 & 1.2 & 0.040 & 0.10 & 13 \\
\hline $7 / 10 / 2003$ & 0915 & 0.48 & 0.018 & 1.10 & 0.007 & 1.6 & 0.198 & 0.27 & 12 \\
\hline $7 / 14 / 2003$ & 1230 & 1.30 & 0.041 & 0.33 & 0.007 & 1.6 & 0.029 & 0.44 & 237 \\
\hline $7 / 23 / 2003$ & 0900 & 0.57 & E 0.013 & 0.80 & 0.005 & 1.4 & 0.080 & 0.17 & 352 \\
\hline $7 / 29 / 2003$ & 1030 & 0.53 & E 0.01 & 0.54 & 0.004 & 1.1 & 0.080 & 0.14 & 8 \\
\hline $8 / 5 / 2003$ & 0900 & 0.78 & 0.032 & 0.38 & 0.005 & 1.2 & 0.047 & 0.19 & 80 \\
\hline $8 / 12 / 2003$ & 0930 & 0.62 & 0.033 & 0.28 & 0.005 & 0.9 & 0.035 & 0.11 & 27 \\
\hline $8 / 27 / 2003$ & 0845 & 0.51 & $<0.015$ & 0.44 & 0.004 & 1.0 & 0.047 & 0.11 & 15 \\
\hline $9 / 3 / 2003$ & 0915 & 0.67 & 0.023 & 0.43 & 0.006 & 1.1 & 0.051 & 0.13 & 27 \\
\hline $9 / 12 / 2003$ & 0900 & 0.47 & $<0.015$ & 0.75 & 0.004 & 1.2 & 0.041 & 0.10 & 10 \\
\hline $9 / 17 / 2003$ & 0915 & 0.79 & $<0.015$ & 1.12 & 0.005 & 1.9 & 0.093 & 0.28 & 177 \\
\hline $9 / 24 / 2003$ & 0915 & 1.00 & 0.043 & 0.24 & 0.007 & 1.3 & 0.031 & 0.28 & 168 \\
\hline $10 / 1 / 2003$ & 0915 & 0.52 & $<0.015$ & 0.55 & E 0.002 & 1.1 & 0.062 & 0.12 & 12 \\
\hline $10 / 7 / 2003$ & 0900 & 0.52 & $<0.01$ & 1.20 & 0.003 & 1.7 & 0.198 & 0.25 & 6 \\
\hline $10 / 15 / 2003$ & 1030 & 0.42 & $<0.01$ & 0.67 & 0.003 & 1.1 & 0.082 & 0.13 & 11 \\
\hline $10 / 20 / 2003$ & 1030 & 0.51 & $<0.01$ & 0.74 & 0.003 & 1.2 & 0.069 & 0.10 & 3 \\
\hline $10 / 31 / 2003$ & 1245 & 0.52 & 0.023 & 0.94 & 0.005 & 1.5 & 0.152 & 0.20 & 12 \\
\hline $11 / 12 / 2003$ & 0900 & 0.45 & $<0.01$ & 1.12 & 0.004 & 1.6 & 0.165 & 0.22 & 6 \\
\hline $11 / 21 / 2003$ & 1000 & 0.54 & 0.023 & 1.23 & 0.005 & 1.8 & 0.165 & 0.23 & 8 \\
\hline $11 / 28 / 2003$ & 1100 & 0.46 & E 0.009 & 0.91 & 0.003 & 1.4 & 0.087 & 0.13 & 4 \\
\hline $12 / 11 / 2003$ & 1330 & 1.00 & 0.042 & 1.18 & 0.007 & 2.2 & 0.075 & 0.28 & 77 \\
\hline $12 / 23 / 2003$ & 1100 & 0.48 & 0.044 & 0.69 & 0.005 & 1.2 & 0.055 & 0.12 & 9 \\
\hline $1 / 6 / 2004$ & 0900 & 0.41 & E 0.005 & 1.29 & 0.005 & 1.7 & 0.084 & 0.13 & 5 \\
\hline $1 / 20 / 2004$ & 0930 & 0.53 & $<0.01$ & 1.28 & 0.006 & 1.8 & 0.056 & 0.11 & 4 \\
\hline $2 / 3 / 2004$ & 0930 & 0.55 & E 0.007 & 1.45 & 0.014 & 2.0 & 0.048 & 0.09 & 11 \\
\hline $2 / 18 / 2004$ & 1100 & 0.48 & 0.063 & 0.86 & 0.015 & 1.3 & 0.059 & 0.12 & 12 \\
\hline $3 / 8 / 2004$ & 0915 & 0.64 & 0.013 & 0.76 & 0.013 & 1.4 & 0.063 & 0.14 & 22 \\
\hline $3 / 18 / 2004$ & 0900 & 0.64 & 0.038 & 0.84 & 0.008 & 1.5 & 0.065 & 0.13 & 15 \\
\hline $3 / 30 / 2004$ & 0930 & 0.56 & 0.023 & 0.84 & 0.006 & 1.4 & 0.307 & 0.37 & 8 \\
\hline $4 / 13 / 2004$ & 1000 & 0.64 & 0.106 & 0.97 & 0.013 & 1.6 & 0.152 & 0.20 & 17 \\
\hline $5 / 12 / 2004$ & 1030 & 0.65 & 0.035 & 0.72 & 0.008 & 1.4 & 0.074 & 0.13 & 35 \\
\hline $5 / 27 / 2004$ & 0900 & 0.57 & 0.048 & 1.02 & 0.010 & 1.6 & 0.266 & 0.33 & 8 \\
\hline $6 / 10 / 2004$ & 0915 & 0.50 & 0.030 & 0.83 & 0.007 & 1.3 & 0.099 & 0.16 & 20 \\
\hline $6 / 22 / 2004$ & 0915 & 0.56 & 0.041 & 1.10 & 0.010 & 1.7 & 0.103 & 0.17 & 16 \\
\hline $7 / 9 / 2004$ & 0930 & 0.54 & 0.094 & 0.56 & 0.006 & 1.1 & 0.060 & 0.11 & 12 \\
\hline $7 / 15 / 2004$ & 0945 & 0.50 & 0.029 & 1.03 & 0.007 & 1.5 & 0.100 & 0.14 & 9 \\
\hline $7 / 20 / 2004$ & 0930 & 0.64 & 0.141 & 1.33 & 0.015 & 2.0 & 0.102 & 0.17 & 28 \\
\hline $7 / 27 / 2004$ & 1415 & 0.60 & 0.025 & 0.94 & 0.005 & 1.5 & 0.095 & 0.14 & 8 \\
\hline $7 / 30 / 2004$ & 1015 & 0.94 & 0.080 & 2.77 & 0.017 & 3.7 & 0.138 & 0.28 & 69 \\
\hline $8 / 3 / 2004$ & 0945 & 0.62 & 0.024 & 0.63 & 0.006 & 1.2 & 0.060 & 0.15 & 26 \\
\hline $8 / 6 / 2004$ & 1015 & 0.58 & 0.035 & 0.75 & 0.006 & 1.3 & 0.066 & 0.14 & 15 \\
\hline $8 / 15 / 2004$ & 0845 & 0.82 & 0.079 & 2.01 & 0.013 & 2.8 & 0.090 & 0.21 & 51 \\
\hline
\end{tabular}


Appendix 2. Nutrient and suspended-sediment concentrations in water samples from the Deep River at Moncure, North Carolina.

[mg/L, milligrams per liter; N, nitrogen; $\mathrm{P}$, phosphorus; - , no data; E, estimated; <, less than]

\begin{tabular}{|c|c|c|c|c|c|c|c|c|c|}
\hline Date & Time & $\begin{array}{c}\text { Ammonia } \\
\text { plus organic } \\
\text { nitrogen, water, } \\
\text { unfiltered, in } \\
\text { mg/L as } \mathbf{N}\end{array}$ & $\begin{array}{l}\text { Ammonia, } \\
\text { water, } \\
\text { filtered, in } \\
\mathrm{mg} / \mathrm{L} \text { as } \mathrm{N}\end{array}$ & $\begin{array}{c}\text { Nitrite } \\
\text { plus nitrate, } \\
\text { water, } \\
\text { filtered, in } \\
\mathrm{mg} / \mathrm{L} \text { as } \mathrm{N}\end{array}$ & $\begin{array}{c}\text { Nitrite, } \\
\text { water, } \\
\text { filtered, in } \\
\mathrm{mg} / \mathrm{L} \text { as } \mathrm{N}\end{array}$ & $\begin{array}{c}\text { Total } \\
\text { nitrogen, } \\
\text { water, } \\
\text { unfiltered, } \\
\text { in } \mathrm{mg} / \mathrm{L} \\
\text { as } \mathrm{N}\end{array}$ & $\begin{array}{c}\text { Ortho- } \\
\text { phosphate, } \\
\text { water, } \\
\text { filtered, in } \\
\mathrm{mg} / \mathrm{L} \text { as } P\end{array}$ & $\begin{array}{c}\text { Phosphorus, } \\
\text { water, } \\
\text { unfiltered, } \\
\text { in } \mathrm{mg} / \mathrm{L}\end{array}$ & $\begin{array}{c}\text { Suspended } \\
\text { sediment, } \\
\text { in } \mathrm{mg} / \mathrm{L}\end{array}$ \\
\hline $8 / 14 / 2002$ & 1300 & 0.63 & 0.018 & 0.18 & 0.005 & 0.8 & 0.568 & - & 1 \\
\hline $8 / 20 / 2002$ & 1345 & 0.68 & 0.020 & 0.47 & 0.009 & 1.1 & 0.704 & - & 4 \\
\hline $8 / 27 / 2002$ & 0930 & 0.81 & 0.072 & 0.34 & 0.011 & 1.1 & 0.806 & - & 18 \\
\hline $9 / 4 / 2002$ & 1530 & 0.96 & 0.134 & 1.14 & 0.018 & 2.1 & 0.149 & - & 18 \\
\hline $9 / 11 / 2002$ & 0945 & 0.79 & 0.049 & 2.14 & 0.028 & 2.9 & 0.47 & - & 6 \\
\hline $9 / 17 / 2002$ & 1230 & 0.68 & 0.023 & 0.91 & 0.009 & 1.6 & 0.202 & - & 17 \\
\hline $9 / 25 / 2002$ & 0845 & 0.62 & 0.023 & 0.67 & 0.006 & 1.3 & 0.213 & - & 28 \\
\hline $10 / 1 / 2002$ & 0915 & 0.60 & 0.019 & 1.82 & 0.011 & 2.4 & 0.518 & - & 6 \\
\hline $10 / 7 / 2002$ & 1315 & 0.55 & 0.016 & 0.92 & 0.007 & 1.5 & 0.389 & - & 2 \\
\hline $10 / 12 / 2002$ & 1130 & 2.70 & 0.155 & 1.20 & 0.020 & 3.9 & 0.138 & - & 468 \\
\hline $10 / 15 / 2002$ & 1130 & 1.20 & 0.184 & 1.09 & 0.022 & 2.3 & 0.128 & - & 27 \\
\hline $10 / 22 / 2002$ & 1030 & 0.70 & 0.057 & 0.86 & 0.011 & 1.6 & 0.124 & - & 20 \\
\hline $10 / 29 / 2002$ & 1115 & 0.64 & 0.019 & 1.22 & 0.009 & 1.9 & 0.159 & - & 10 \\
\hline $11 / 5 / 2002$ & 0915 & 0.90 & 0.021 & 0.93 & 0.009 & 1.8 & 0.152 & - & 7 \\
\hline $11 / 12 / 2002$ & 1030 & 0.75 & 0.022 & 1.08 & 0.013 & 1.8 & 0.151 & - & 8 \\
\hline $11 / 19 / 2002$ & 1330 & 0.91 & 0.032 & 0.59 & 0.007 & 1.5 & 0.118 & 0.22 & 38 \\
\hline $11 / 26 / 2002$ & 1115 & 0.53 & Е 0.014 & 0.88 & 0.005 & 1.4 & 0.096 & 0.13 & 4 \\
\hline $12 / 3 / 2002$ & 1030 & 0.48 & E 0.011 & 1.15 & 0.004 & 1.6 & 0.129 & 0.17 & 4 \\
\hline $12 / 9 / 2002$ & 1100 & 0.80 & 0.045 & 0.91 & 0.006 & 1.7 & 0.1 & 0.17 & 17 \\
\hline $12 / 17 / 2002$ & 1100 & 0.63 & 0.047 & 0.72 & 0.006 & 1.4 & 0.072 & 0.15 & 19 \\
\hline $1 / 8 / 2003$ & 1100 & 0.50 & 0.040 & 0.79 & 0.010 & 1.3 & 0.112 & 0.18 & 9 \\
\hline $1 / 14 / 2003$ & 1045 & 0.39 & 0.028 & 0.99 & 0.011 & 1.4 & 0.1 & 0.14 & 6 \\
\hline $1 / 21 / 2003$ & 1030 & 0.33 & E 0.012 & 1.17 & 0.005 & 1.5 & 0.092 & 0.12 & 3 \\
\hline $1 / 30 / 2003$ & 1130 & 0.35 & E 0.011 & 1.73 & 0.011 & 2.1 & 0.216 & 0.25 & 4 \\
\hline $2 / 5 / 2003$ & 1115 & 0.75 & 0.301 & 0.96 & 0.015 & 1.7 & 0.109 & 0.16 & 15 \\
\hline $2 / 11 / 2003$ & 1100 & 0.52 & 0.050 & 0.69 & 0.012 & 1.2 & 0.053 & 0.12 & 16 \\
\hline $2 / 21 / 2003$ & 1000 & 0.60 & 0.051 & 0.74 & 0.008 & 1.3 & 0.09 & 0.17 & 18 \\
\hline $2 / 25 / 2003$ & 1030 & 0.82 & 0.094 & 0.57 & 0.009 & 1.4 & 0.048 & 0.19 & 66 \\
\hline $3 / 6 / 2003$ & 1445 & 1.00 & 0.029 & 0.46 & 0.006 & 1.5 & 0.07 & 0.30 & 205 \\
\hline $3 / 21 / 2003$ & 1030 & 1.70 & 0.096 & 0.39 & 0.008 & 2.0 & 0.128 & 0.54 & 309 \\
\hline $3 / 24 / 2003$ & 0945 & 0.70 & 0.074 & 0.35 & 0.008 & 1.1 & 0.048 & 0.16 & 45 \\
\hline $4 / 1 / 2003$ & 1030 & 1.30 & 0.058 & 0.64 & 0.009 & 1.9 & 0.086 & 0.19 & 31 \\
\hline $4 / 8 / 2003$ & 1115 & 0.81 & 0.050 & 0.46 & 0.006 & 1.3 & 0.064 & 0.21 & 91 \\
\hline $4 / 10 / 2003$ & 1145 & 1.00 & 0.070 & 0.33 & 0.006 & 1.4 & 0.116 & 0.30 & 125 \\
\hline $4 / 15 / 2003$ & 1015 & 0.70 & 0.113 & 0.39 & 0.008 & 1.1 & 0.051 & 0.12 & 148 \\
\hline $4 / 22 / 2003$ & 1115 & 0.39 & 0.022 & 0.66 & 0.004 & 1.1 & 0.055 & 0.08 & 9 \\
\hline $5 / 2 / 2003$ & 0945 & 0.44 & $<0.015$ & 0.86 & 0.006 & 1.3 & 0.095 & 0.13 & 4 \\
\hline $5 / 9 / 2003$ & 0900 & 0.85 & 0.071 & 0.58 & 0.012 & 1.4 & 0.111 & 0.19 & 20 \\
\hline $5 / 14 / 2003$ & 1300 & 0.55 & Е 0.008 & 0.81 & 0.009 & 1.4 & 0.137 & 0.18 & 20 \\
\hline $5 / 28 / 2003$ & 1100 & 0.77 & 0.045 & 0.47 & 0.012 & 1.2 & 0.095 & 0.21 & 61 \\
\hline $6 / 2 / 2003$ & 0945 & 0.65 & 0.019 & 0.57 & 0.008 & 1.2 & 0.079 & 0.18 & 31 \\
\hline $6 / 13 / 2003$ & 1100 & 0.68 & 0.020 & 0.53 & 0.008 & 1.2 & 0.134 & 0.22 & 30 \\
\hline $6 / 20 / 2003$ & 1100 & 1.10 & 0.062 & 0.51 & 0.011 & 1.6 & 0.108 & 0.31 & 120 \\
\hline
\end{tabular}


Appendix 2. Nutrient and suspended-sediment concentrations in water samples from the Deep River at Moncure, North Carolina.-Continued

[mg/L, milligrams per liter; N, nitrogen; P, phosphorus; - , no data; E, estimated; <, less than]

\begin{tabular}{|c|c|c|c|c|c|c|c|c|c|}
\hline Date & Time & $\begin{array}{c}\text { Ammonia } \\
\text { plus organic } \\
\text { nitrogen, water, } \\
\text { unfiltered, in } \\
\text { mg/L as } N\end{array}$ & $\begin{array}{l}\text { Ammonia, } \\
\text { water, } \\
\text { filtered, in } \\
\text { mg/L as } N\end{array}$ & $\begin{array}{c}\text { Nitrite } \\
\text { plus nitrate, } \\
\text { water, } \\
\text { filtered, in } \\
\text { mg/L as N }\end{array}$ & $\begin{array}{c}\text { Nitrite, } \\
\text { water, } \\
\text { filtered, in } \\
\text { mg/L as N }\end{array}$ & $\begin{array}{c}\text { Total } \\
\text { nitrogen, } \\
\text { water, } \\
\text { unfiltered, } \\
\text { in } \mathrm{mg} / \mathrm{L} \\
\text { as } \mathrm{N}\end{array}$ & $\begin{array}{c}\text { Ortho- } \\
\text { phosphate, } \\
\text { water, } \\
\text { filtered, in } \\
\text { mg/L as P }\end{array}$ & $\begin{array}{l}\text { Phosphorus, } \\
\text { water, } \\
\text { unfiltered, } \\
\text { in mg/L }\end{array}$ & $\begin{array}{c}\text { Suspended } \\
\text { sediment, } \\
\text { in } \mathrm{mg} / \mathrm{L}\end{array}$ \\
\hline $6 / 24 / 2003$ & 1030 & 0.71 & 0.019 & 0.78 & 0.009 & 1.5 & 0.154 & 0.24 & 12 \\
\hline $7 / 3 / 2003$ & 0915 & 1.10 & 0.058 & 0.58 & 0.010 & 1.7 & 0.162 & 0.41 & 197 \\
\hline $7 / 10 / 2003$ & 1045 & 0.55 & $<0.015$ & 0.78 & 0.005 & 1.3 & 0.156 & 0.23 & 9 \\
\hline $7 / 16 / 2003$ & 1000 & 0.58 & 0.015 & 0.80 & 0.004 & 1.4 & 0.103 & 0.18 & 27 \\
\hline $7 / 23 / 2003$ & 1030 & 0.59 & 0.016 & 0.88 & 0.005 & 1.5 & 0.143 & 0.21 & 15 \\
\hline $7 / 29 / 2003$ & 1130 & 0.61 & $<0.015$ & 1.30 & 0.006 & 1.9 & 0.163 & 0.26 & 12 \\
\hline $8 / 5 / 2003$ & 1030 & 0.88 & 0.060 & 0.46 & 0.009 & 1.3 & 0.125 & 0.27 & 53 \\
\hline $8 / 27 / 2003$ & 1015 & 0.51 & $<0.015$ & 0.70 & 0.003 & 1.2 & 0.114 & 0.19 & 10 \\
\hline $9 / 3 / 2003$ & 1045 & 0.62 & 0.029 & 1.19 & 0.010 & 1.8 & 0.119 & 0.23 & 40 \\
\hline $9 / 12 / 2003$ & 1045 & 0.57 & $<0.015$ & 0.72 & 0.004 & 1.3 & 0.156 & 0.24 & 17 \\
\hline $9 / 17 / 2003$ & 1030 & 0.51 & $<0.015$ & 0.81 & 0.004 & 1.3 & 0.14 & 0.23 & 10 \\
\hline $9 / 24 / 2003$ & 1030 & 1.20 & $<0.015$ & 0.53 & 0.004 & 1.7 & 0.098 & 0.41 & 195 \\
\hline $10 / 1 / 2003$ & 1100 & 0.61 & $<0.015$ & 0.58 & 0.004 & 1.2 & 0.126 & 0.23 & 41 \\
\hline $10 / 7 / 2003$ & 1030 & 0.50 & $<0.01$ & 0.79 & 0.004 & 1.3 & 0.133 & 0.21 & 6 \\
\hline $10 / 15 / 2003$ & 1200 & 0.34 & E 0.007 & 0.91 & 0.004 & 1.3 & 0.096 & 0.15 & 6 \\
\hline $10 / 20 / 2003$ & 1200 & 0.47 & E 0.007 & 1.18 & 0.004 & 1.6 & 0.149 & 0.20 & 7 \\
\hline $10 / 31 / 2003$ & 1430 & 0.45 & E 0.009 & 0.82 & 0.004 & 1.3 & 0.074 & 0.11 & 13 \\
\hline $11 / 12 / 2003$ & 1030 & 0.45 & $<0.01$ & 0.88 & 0.003 & 1.3 & 0.137 & 0.19 & 6 \\
\hline $11 / 21 / 2003$ & 1200 & 0.47 & E 0.005 & 0.95 & 0.003 & 1.4 & 0.109 & 0.18 & 9 \\
\hline $11 / 28 / 2003$ & 1215 & 0.44 & $<0.01$ & 1.58 & 0.004 & 2.0 & 0.241 & 0.33 & 10 \\
\hline $12 / 11 / 2003$ & 1500 & 1.60 & 0.099 & 1.27 & 0.011 & 2.9 & 0.168 & 0.46 & 162 \\
\hline $12 / 23 / 2003$ & 1230 & 0.54 & 0.022 & 1.07 & 0.006 & 1.6 & 0.091 & 0.16 & 10 \\
\hline $1 / 6 / 2004$ & 1045 & 0.31 & E 0.009 & 1.23 & 0.002 & 1.5 & 0.091 & 0.14 & 7 \\
\hline $1 / 20 / 2004$ & 1100 & 0.36 & $<0.01$ & 1.08 & 0.002 & 1.4 & 0.071 & 0.13 & 9 \\
\hline $2 / 3 / 2004$ & 1100 & 0.36 & $<0.01$ & 1.12 & 0.002 & 1.5 & 0.051 & 0.09 & 5 \\
\hline $2 / 18 / 2004$ & 1300 & 0.52 & 0.034 & 0.79 & 0.007 & 1.3 & 0.06 & 0.12 & 16 \\
\hline $3 / 8 / 2004$ & 1045 & 0.49 & 0.022 & 0.80 & 0.008 & 1.3 & 0.084 & 0.15 & 10 \\
\hline $3 / 18 / 2004$ & 1100 & 0.74 & 0.040 & 0.79 & 0.007 & 1.5 & 0.057 & 0.14 & 32 \\
\hline $3 / 30 / 2004$ & 1100 & 0.38 & $<0.01$ & 0.64 & 0.003 & 1.0 & 0.068 & 0.12 & 8 \\
\hline 4/13/2004 & 1200 & 0.43 & 0.026 & 0.55 & 0.003 & 1.0 & 0.076 & 0.11 & 10 \\
\hline $5 / 12 / 2004$ & 1145 & 0.60 & 0.024 & 1.07 & 0.011 & 1.7 & 0.133 & 0.21 & 12 \\
\hline $5 / 27 / 2004$ & 1030 & 0.42 & 0.027 & 0.71 & 0.008 & 1.1 & 0.136 & 0.21 & 9 \\
\hline $6 / 10 / 2004$ & 1115 & 0.57 & 0.024 & 1.52 & 0.011 & 2.1 & 0.231 & 0.31 & 12 \\
\hline $6 / 22 / 2004$ & 1045 & 0.50 & 0.019 & 1.40 & 0.006 & 1.9 & 0.351 & 0.40 & 8 \\
\hline $7 / 9 / 2004$ & 1115 & 0.60 & 0.013 & 1.26 & 0.006 & 1.9 & 0.198 & 0.26 & 12 \\
\hline $7 / 15 / 2004$ & 1115 & 0.60 & 0.021 & 1.01 & 0.008 & 1.6 & 0.236 & 0.31 & 8 \\
\hline $7 / 20 / 2004$ & 1115 & 0.59 & 0.012 & 1.03 & 0.005 & 1.6 & 0.316 & 0.39 & 23 \\
\hline $7 / 27 / 2004$ & 1530 & 0.57 & 0.022 & 1.40 & 0.009 & 2.0 & 0.334 & 0.39 & 5 \\
\hline 7/30/2004 & 1130 & 0.68 & 0.039 & 1.96 & 0.014 & 2.6 & 0.354 & 0.43 & 19 \\
\hline $8 / 3 / 2004$ & 1045 & 0.58 & 0.022 & 0.82 & 0.006 & 1.4 & 0.223 & 0.29 & 9 \\
\hline $8 / 6 / 2004$ & 1130 & 0.73 & 0.026 & 1.61 & 0.015 & 2.3 & 0.244 & 0.33 & 9 \\
\hline $8 / 10 / 2004$ & 1015 & 0.58 & 0.027 & 1.68 & 0.009 & 2.3 & 0.304 & 0.35 & 2 \\
\hline $8 / 15 / 2004$ & 0945 & 1.40 & 0.405 & 0.81 & 0.014 & 2.2 & 0.205 & 0.33 & 57 \\
\hline
\end{tabular}




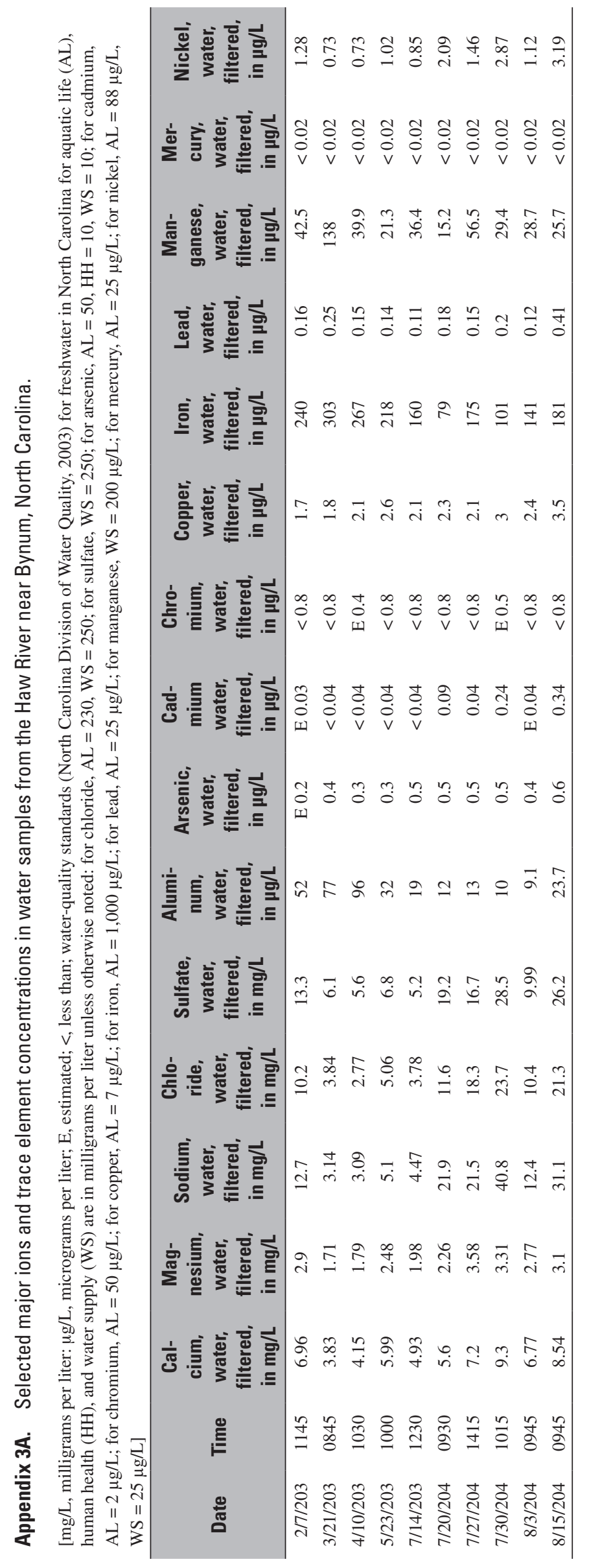




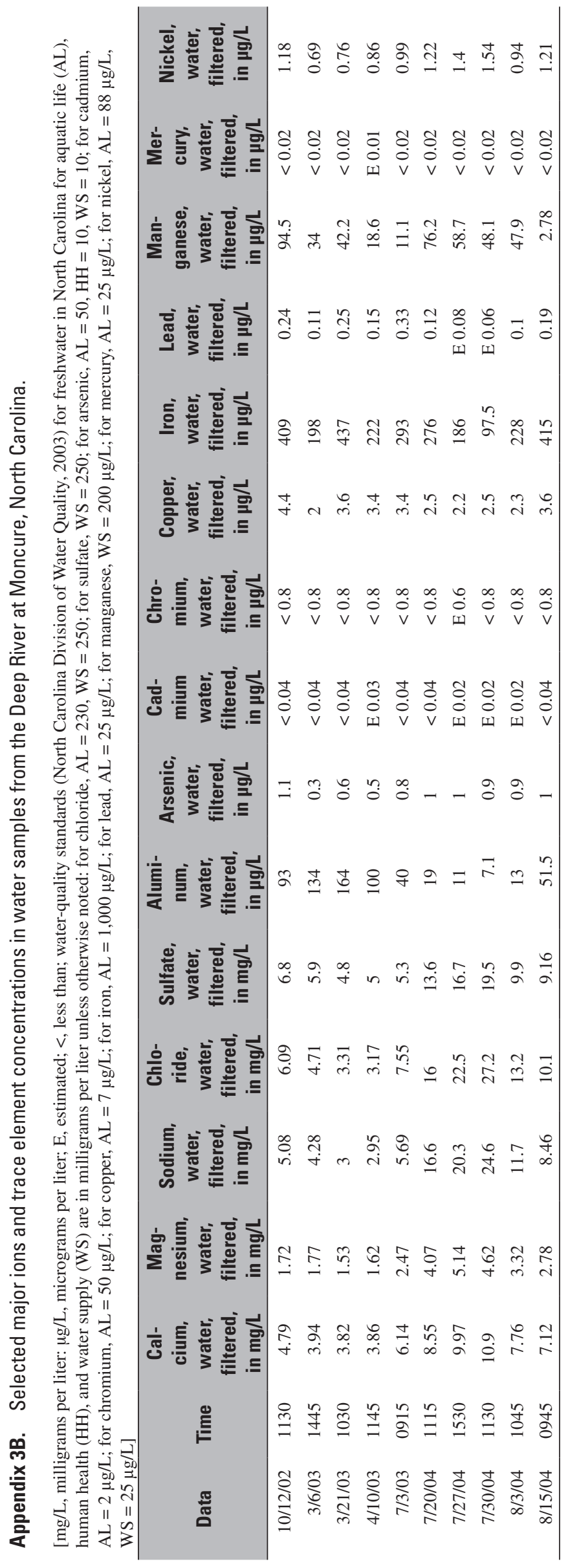




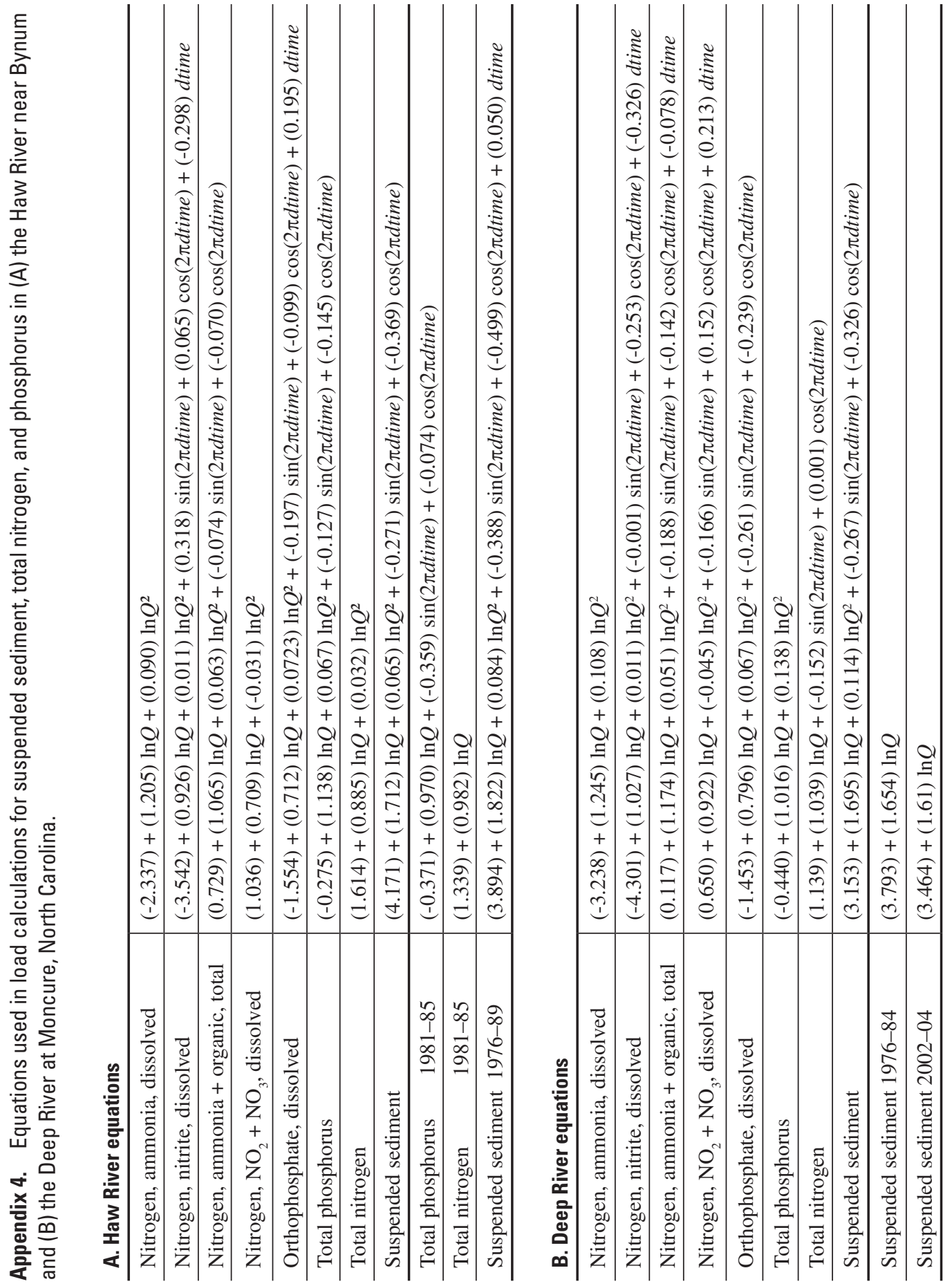


Appendix 5. Planted crop acreage in counties in the upper Cape Fear River basin, 1980-2004.

[Data are from the U.S. Department of Agriculture (2004)]

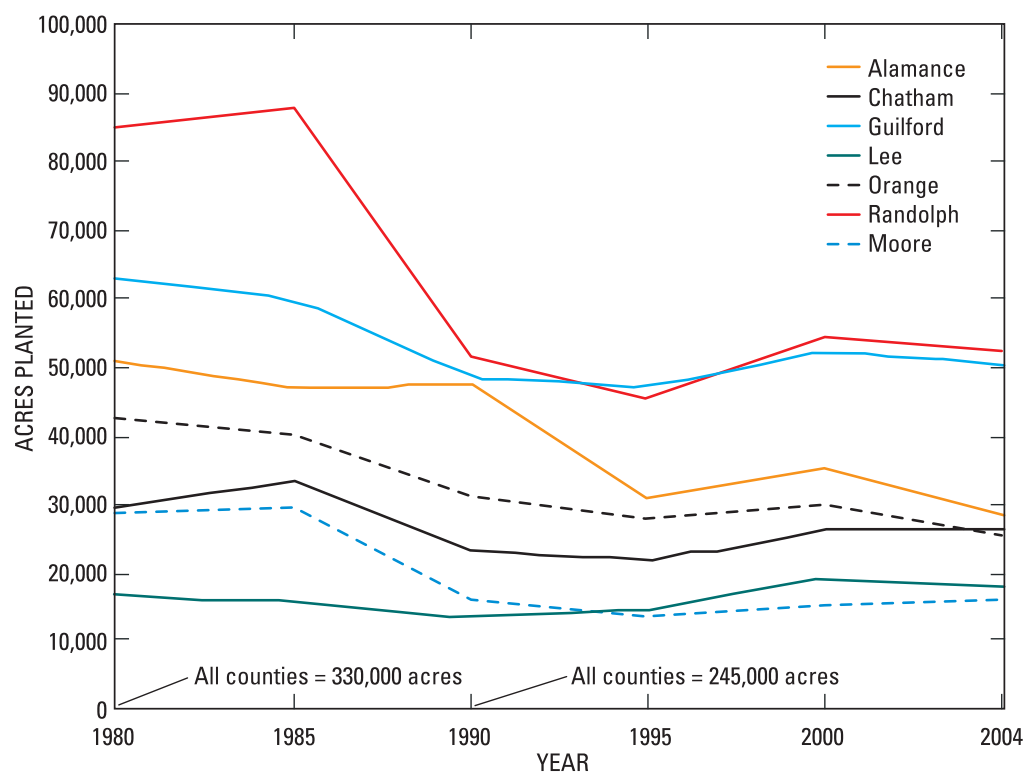




\section{Prepared by:}

U.S. Geological Survey

Enterprise Publishing Network

North Carolina Water Science Center

3916 Sunset Ridge Road

Raleigh, NC 27607

A PDF version of this publication is available online at URL

http://pubs.water.usgs.gov/sir2005-5271/ 


\section{$\frac{1}{4}$}

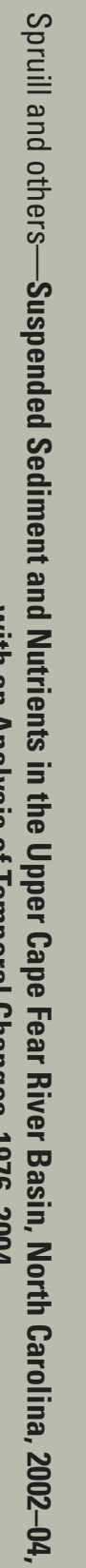

